\title{
ORIGEM, EVOLUÇÃO E DIRECIONAMENTO DA PROTEÍNA THI1 EM PLANTAS
}

\author{
JULIANA DANTAS DE ALMEIDA
}

Tese apresentada à Escola Superior de Agricultura "Luiz de Queiroz", Universidade de São Paulo, para obtenção de título de Doutor em Agronomia, Área de Concentração: Genética E Melhoramento de Plantas.

P I R A C I C A B A

Estado de São Paulo - Brasil

Fevereiro - 2004 


\section{ORIGEM, EVOLUÇÃO E DIRECIONAMENTO DA PROTEÍNA THI1 EM PLANTAS}

JULIANA DANTAS DE ALMEIDA

Bacharel e Licenciada em Ciências Biológicas

Orientador: Prof. Dr. MARCIO DE CASTRO SILVA FILHO

Tese apresentada à Escola Superior de Agricultura "Luiz de Queiroz", Universidade de São Paulo, para obtenção de título de Doutor em Agronomia, Área de Concentração: Genética E Melhoramento de Plantas.

P I R A C I C A B A

Estado de São Paulo - Brasil

Fevereiro - 2004 


\section{Dados Internacionais de Catalogação na Publicação (CIP)}

DIVISÃO DE BIBLIOTECA E DOCUMENTAÇÃO - ESALQ/USP

Almeida, Juliana Dantas de

Origem, evolução e direcionamento da proteína TH1 em plantas / Juliana Dantas de Almeida. - - Piracicaba, 2004.

94 p. : il.

Tese (doutorado) - Escola Superior de Agricultura Luiz de Queiroz, 2004.

Bibliografia.

1. Biologia celular 2. Enzimas 3. Expressão gênica 4. Filogenia 5. Genes

6.

Plantas trasngênicas 7. Proteínas de plantas I. Título

CDD 575.1

"Permitida a cópia total ou parcial deste documento, desde que citada a fonte - O autor" 


\section{OFEREÇO}

Àqueles que apostam na ciência para produção do conhecimento.

"Sempre que alguém quer esgotar um assunto, esgota a paciência do leitor."

Oscar Wilde 


\section{AGRADECIMENTOS}

Ao Prof. Dr. Marcio de Castro Silva Filho pela orientação, pelos conhecimentos transmitidos, pela confiança, pelo incentivo e pelo exemplo de dedicação, eficiência e competência.

À Prof ${ }^{\mathrm{a}}$. Dra. Marie-Anne van Sluys, IB, USP e ao Prof. Dr. Carlos F. M. Menck, ICB2 - USP, pela colaboração, discussões de resultados, sugestões e amizade.

Ao Prof. Alberto Ribeiro, IB - USP e a Waldir Caldeira, pela realização das análises de microscopia confocal.

Aos colegas do Laboratório de Citogenética, ESALQ - USP, em especial a Dra. Janay A. Santos, Dra. Sílvia M. Cuco e Dr. Mateus Mondin, pelo apoio técnico na utilização do microscópio e à Prof ${ }^{a}$ Dra Margarida L. R. de Aguiar Perecin por colocar seu laboratório à disposição.

A todos os professores, alunos e funcionários do Departamento de Genética da ESALQ - USP, especialmente aos funcionários do setor de manutenção pelos freqüentes reparos na sala de cultivo de Arabidopsis thaliana.

A Phellippe Arthur Santos Marbach pelo companheirismo, profissionalismo e parceria nas análises filogenéticas e Carolina Morgante Vianna pela significativa ajuda na confecção da tese.

Aos colegas do Laboratório de Biologia Molecular de Plantas, ESALQ USP, pela amizade, paciência e incentivo em todos os momentos. Pelas riquíssimas discussões de cunho científico e pelos momentos de descontração. 
À Fapesp, Fundação de Amparo à Pesquisa do Estado de São Paulo pelo apoio financeiro.

De maneira muito especial à Hélio da Costa Almeida e Maria Auxiliadora Dantas Almeida, meus pais. À Maria do Carmo Dantas e Maria Rita Dantas, minhas tias. À Marcus Vinícius Romano Lemos. Pessoas por quem tenho admiração e amor profundos e que estão sempre comigo em todos os momentos apesar das distâncias físicas. 


\section{SUMÁRIO}

\begin{tabular}{|c|c|}
\hline 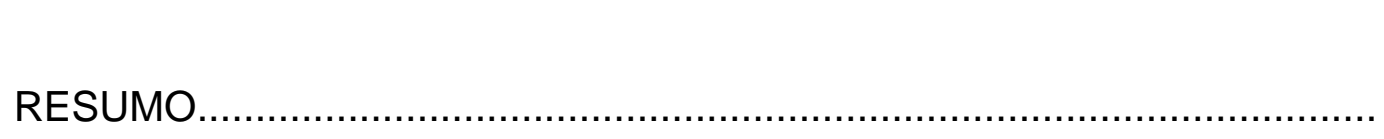 & $\begin{array}{c}\text { Página } \\
\text { viii }\end{array}$ \\
\hline SUMMARY. & $x$ \\
\hline 1 INTRODUÇÃO...... & 1 \\
\hline 2 REVISÃO DE LITERATURA.... & 3 \\
\hline 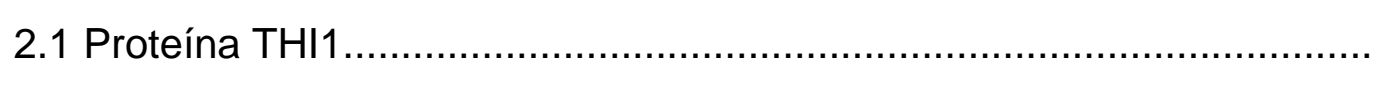 & 3 \\
\hline 2.2 Importação de proteínas para mitocôndrias e cloroplastos....................... & 6 \\
\hline 2.2.1 Importação de proteínas em mitocôndrias... & 6 \\
\hline 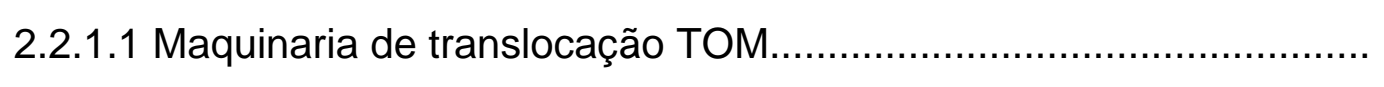 & 9 \\
\hline 2.2.1.2 Maquinaria de translocação TIM... & 12 \\
\hline 2.2.1.3 Processamento de precursores mitocondriais................ & 14 \\
\hline 2.2.1.4 Características estruturais dos precursores da matriz mitocondrial. & 15 \\
\hline 2.2.2 Importação de proteínas para os cloroplastos...... & 16 \\
\hline 2.2.2.1 Direcionamento de proteínas aos envelopes externo e interno........ & 18 \\
\hline 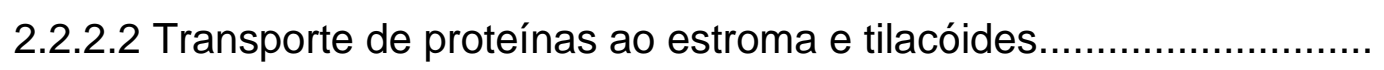 & 22 \\
\hline 2.3 Duplo direcionamento...... & 24 \\
\hline 3 MATERIAL E MÉTODOS..... & 30 \\
\hline 3.1 Endereçamento da proteína THI1 de Arabidopsis thaliana.................. & 30 \\
\hline 3.1.1 Cassetes de expressão & 30 \\
\hline 3.1.1.1 Seqüênciamento das regiões de ligação do fragmento thi1 ao & \\
\hline
\end{tabular}


3.1.1.2 Amplificação dos fragmentos de DNA correspondentes às seqüências do promotor $35 \mathrm{~S}$ e às regiões codificadoras das proteínas THI1 e GFP......

3.1.1.3 Obtenção do fragmento Pr4 correspondente ao promotor thi1........ 33

3.1.1.4 Clonagem dos fragmentos em vetor pBSK ${ }^{-}$................................... 33

3.1.1.5 Transferência dos cassetes de expressão 1, 2, 3 e 4 para o vetor

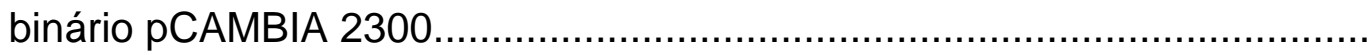

3.1.1.6 Armazenamento das bactérias transformadas com os plasmídeos utilizados nas construções gênicas.

3.1.2 Material vegetal.

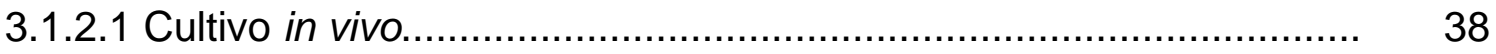

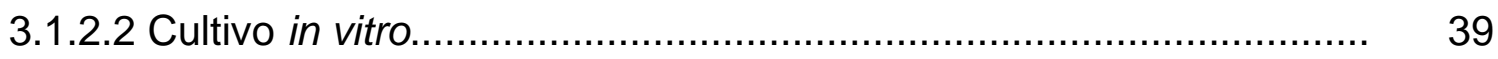

3.1.3 Transformação de Arabidopsis thaliana........................................... 39

3.1.3.1 Transformação de Agrobacterium tumefaciens GV3101::pMP90.... 39

3.1.3.2 Inoculação de Arabidopsis thaliana................................................ 40

3.1.3.3 Seleção e diagnóstico das plantas transformadas.......................... 41

3.1.4 Análise de Arabidopsis thaliana transgênica em microscópio confocal.

3.1.4.1 Condições da análise no confocal.............................................. 41

3.1.4.2 Tratamento com "MitoTracker".................................................. 42

3.2 Endereçamento de THI1 de cana de açúcar........................................ 42

3.2.1 Cassetes de expressão................................................................ 42

3.2.1.1 Oligonucleotídeos iniciadores e amplificação dos fragmentos contendo a seqüência de direcionamento dos parálogos de THI1 de cana

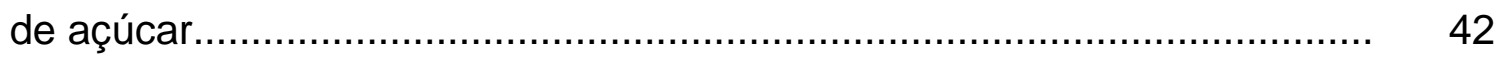

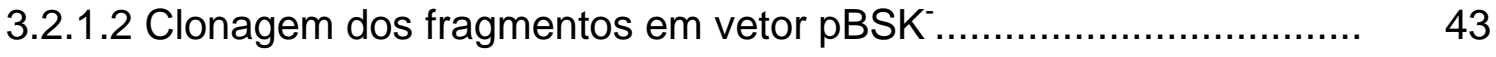

3.2.2 Transformação via biobalística....................................................... 44

3.2.2.1 Visualização de GFP............................................................... 44

3.2.3 Análises filogenéticas................................................................. 46

4 RESULTADOS E DISCUSSÃO 47 
4.1 THI1 em cana de açúcar: direcionamento e filogenia

4.1.1 Isoformas de THI1 de cana de açúcar estão presentes apenas em cloroplastos

4.1.2 THI1 é provavelmente herança de Archaea.................................... 54

4.2 Localização subcelular de THI1 em Arabidopsis thaliana..................... 57

4.2.1 Análise da localização subcelular de THI1 em diferentes tecidos...... 57

4.2.1.1 THI1 está presente majoritariamente em cloroplastos de Arabidopsis thaliana expressando a construção Pr4+THI1+smGFPnos.....

4.2.1.2 Análise da localização subcelular de THI1 em diferentes etapas do desenvolvimento

4.2.1.3 Análise da localização subcelular de THI1 em diferentes concentrações de tiamina e tiamina pirofosfato

4.2.1.4 A proteína quimérica THI1-GFP não é expressa em plantas de Arabidopsis thaliana transgênica contendo a construção 35S+THI1+smGFPnos

5 CONCLUSÕES 


\title{
ORIGEM, EVOLUÇÃO E DIRECIONAMENTO DA PROTEÍNA THI1 EM PLANTAS
}

\author{
Autora: Juliana Dantas de Almeida \\ Orientador: Prof. Dr. Marcio de Castro Silva Filho
}

\section{RESUMO}

THI1 é provavelmente uma proteína bifuncional, uma vez que está envolvida na biossíntese de tiamina e na estabilidade do DNA organelar, notadamente o mitocondrial. Interessantemente, a biossíntese de tiamina ocorre em compartimentos distintos em plantas (cloroplastos) e em leveduras (mitocôndrias). Ensaios de complementação funcional mostraram que o gene thi1 de Arabidopsis thaliana é capaz de complementar uma cepa mutante de levedura para o gene ortólogo. A proteína THI1 de Arabidopsis thaliana é codificada por um único gene. Uma análise detalhada da região $\mathrm{N}$-terminal da proteína, responsável pela sua localização na células, revelou a presença de duas sequências de direcionamento adjacentes. Na extremidade N-terminal encontra-se um peptídeo de trânsito cloroplástico seguida por uma região capaz de formar uma $\alpha$-hélice anfifílica, tipicamente encontrada em pré-sequências de direcionamento mitocondriais. Com o objetivo de avaliar se a localização final de THI1 pode apresentar um tipo de regulação temporal ou espacial, foram obtidas plantas transgênicas expressando a proteína THI1 fundida a GFP 
("green fluorescent protein"). Análises dessas plantas por meio de microscopia confocal revelaram que THI1 está presente majoritariamente em cloroplastos e raramente em mitocôndrias. Ao contrário do que acontece em Arabidopsis thaliana, em cana de açúcar foram encontrados pelo menos três isoformas/parálogos de thi1. O alinhamento da seqüência de aminoácidos dessas isoformas com a THI1 de Arabidopsis thaliana revelou alta similaridade, inclusive na seqüência de direcionamento. Com o intuito de avaliar o padrão de direcionamento dessas isoformas de cana de açúcar foram obtidas construções gênicas contendo ou a seqüência de direcionamento completa ou o peptídeo de trânsito cloroplástico ou a pré-seqüência mitocondrial, fundidas a GFP sob o comando do promotor 35S. A expressão transiente dessas construções em epiderme de cebola, revelou que no caso das construções contendo a seqüência de direcionamento completa ou o peptídeo de trânsito, o direcionamento ocorreu apenas para os cloroplastos. No caso das construções contendo somente a seqüência de direcionamento mitocondrial a GFP permaneceu difundida no citoplasma.

Além do aspecto do direcionamento, THI1 foi avaliada sob o ponto de vista filogenético. As análises filogenéticas mostram que thi1 é raramente encontrado em bactérias mas é amplamente distribuído em Archaea. As distâncias genéticas indicam que provavelmente os eucariontes herdaram thi1 de Archaea. As poucas bactérias que possuem esse gene provavelmente obtiveram-no por meio de herança horizontal. 


\section{ORIGIN, EVOLUTION AND TARGETING OF THI1 PROTEIN IN PLANTS}

Author: Juliana Dantas de Almeida

Advisor: Prof. Dr. Marcio de Castro Silva Filho

\section{SUMMARY}

THI is probably a bifunctional protein, since it is involved in thiamin biosynthesis and organelar genome stability mainly the mitochondrial. Interestingly, the thiamin biosynthesis occurs at different compartments in plants (chloroplasts) and yeasts (mitochondria). Functional complementation assays showed that Arabidopsis thaliana thi1 gene is able to complement a yeast mutant strain for the hortolog gene. The Arabidopsis thaliana THI1 is encoded by a single copy gene. A detailed analysis of the THI1 N-terminal region, that is responsible for its targeting in cells, reveled the presence of two in tanden directing sequences. At $\mathrm{N}$-terminal region there is a chloroplastic transit peptide followed by a region able to form an anfifilic $\alpha$-helix frequently present in mitochondrial presequences. Aiming to evaluate if the THI1 final localization could present a temporal or spacial regulation, transgenic plants expressing THI1 fused to GFP ("green fluorescent protein") where obtained. Confocal microscopy analysis of these transgenic plants showed that THI is mainly found in chloroplasts and barely found in mitochondrias. Different from what happens in Arabidopsis thaliana, in sugar cane where founded at least three thi1 
isoforms/paralogs. The amino acids sequence alignment of these isoforms with the thi1 one, reveled high similarity including the targeting sequence. To evaluate the directing standard of these sugarcane isoforms, gene constructions made by the complete targeting sequence or the chloroplastic transit peptide or the mitochondrial presequence, fused to GFP under the guidance of $35 \mathrm{~S}$ promotor, where obtained. A transient expression of these gene constructios in epidermal onion cells prove that in the case of the constructions containing either the complete targeting sequence or the chloroplastic transit peptide the directing occurred only to chloroplasts. On the other hand, the constructions containing the mitochondrial pre sequence, GFP were kept defused in the citoplasm.

Besides the directing aspect, THI1 were evaluated under the filogenetic point of view. Filogenetic analysis showed that thi1 is rarely found in bacteria but is widely distributed in Archaea. The genetic distances pointed out that probably eucaryotes THI1 came from Archaea. This gene in a few bacterias probably were inherited by lateral transference. 


\section{INTRODUÇÃo}

Tiamina pirofosfato é a forma ativa da vitamina B-1 e funciona como cofator essencial para atividade de várias enzimas associadas a vias metabólicas majoritárias (Jacob-Wilk et al., 1997).

As plantas e vários microorganismos são capazes de sintetizar tiamina de novo, entretanto, em seres humanos e outros animais seu suprimento é garantido via alimentação. Apesar de vir sendo extensivamente estudada em leveduras, a via de síntese de tiamina ainda não foi completamente caracterizada nesse organismo (Young, 1986). Os estudos da via de síntese de tiamina em plantas são limitados mas ensaios bioquímicos (Mitsuda et al., 1971) e de complementação de mutantes (Proebsting et al., 1990) demonstraram que os precursores de tiamina em plantas e em leveduras são os mesmos embora as vias que levam a esses precursores ainda não tenham sido determinadas.

Em 1994, Praekelt e colaboradores identificaram um gene de Saccharomyces cerevisae responsável pela codificação de uma enzima envolvida na síntese de tiamina. O gene foi denominado THI4. Recentemente, um gene apresentando alta homologia com THI4 foi identificado em Zea mays. Esse gene foi denominado thi1, é capaz de complementar a deleção de THI4 em leveduras e está presente nas membranas dos plastídeos das células de milho (Belanger et al., 1995).

Dados da literatura, indicam que o produto do gene thi1 exerce várias funções na planta como: reparo de DNA mitocondrial (Machado et al., 1996), 
biossíntese de tiamina (Belanger et al., 1995) e maturação de frutos (Jacob-Wilk et al., 1997).

Além de sua multifuncionalidade, o produto do gene thi1 apresenta uma outra característica interessante: é codificado por um único transcrito nuclear e direcionado às mitocôndrias e cloroplastos (Chabregas et al., 2001).

As proteínas THI1 de Arabidopsis thaliana e de milho possuem em sua extremidade N-terminal, uma seqüência de direcionamento típica de cloroplastos mas uma análise mais detalhada da proteína de Arabidopsis thaliana revela motivos de direcionamento típicos de mitocôndria.

Estudos recentes têm demonstrado que fatores ambientais ou modificações pós-traducionais podem interferir na localização final de uma proteína na célula (Anandatheerthavarada et al., 1999; Kircher et al 1999; Rodríguez-Concepción et al 1999 ).

A proteína THI1 fornece um excelente sistema para o estudo de possíveis efeitos ambientais na sua localização final. Resultados preliminares mostraram que a expressão do gene thi1 é regulada pela luz (Pappini-Terzi et al., 2003).

Sendo assim, temos como objetivo 1)estudar a localização da proteína THI1 em plantas transgênicas, expressando GFP sob o controle do promotor de thi1 e do promotor constitutivo 35S; 2) Analisar a localização subcelular de THI1 em diferentes etapas do desenvolvimento; 3) Analisar a localização subcelular de THI1 em diferentes tecidos; 4) Analisar a localização subcelular de THI1 em diferentes concentrações de tiamina e tiamina pirofosfato; 5) Avaliar o direcionamento de diferentes isoformas de THI1 de cana de açúcar; 6) Estudar a filogenia do gene thi1. 


\section{REVISÃO DE LITERATURA}

\subsection{Proteína THI1}

Tiamina ou vitamina B1 é um constituinte essencial de todas as células, pois atua como cofator em dois complexos enzimáticos envolvendo o ciclo do ácido cítrico, piruvato desidrogenase e a-cetoglutarato desidrogenase. Tiamina é sintetizada em plantas e microorganismos, entretanto, em seres humanos e outros animais seu suprimento é garantido via alimentação. A via biossintética da tiamina é bem caracterizada em microrganismos, enquanto que em plantas, o processo é muito pouco conhecido. Em 1995, foram isolados dois cDNAs de milho que codificam proteínas envolvidas na síntese de tiamina. Esses cDNAs, pertencentes à família do gene thi1, foram isolados por meio de ensaios de complementação em uma linhagem de levedura na qual o gene endógeno foi inativado. Análises de "imunoblot" identificaram que o produto desse gene de milho localiza-se na fração plastidial (Belanger et al., 1995).

Machado et al. (1996) realizaram ensaios de complementação em uma linhagem mutante (BW535) de Escherichia coli, deficiente no reparo de DNA por excisão de base, para localizar genes envolvidos nessa via em Arabidopsis thaliana. Surpreendentemente, um dos cDNAs isolados (thi1) apresentou alta homologia a dois genes envolvidos na biossíntese de tiamina em leveduras: thi4 de Saccharomyces cerevisae e nmt2 de Schizosaccharomyces pombe (Manetti et al., 1994), além de um gene de duas espécies de Fusarium relacionado a estresse (sti35) (Choi et al., 1990). 
Buscas nas seqüências do banco de dados de Arabidopsis thaliana revelaram que thi1 está presente em cópia única no genoma desta planta. A proteína putativa apresentou vários motivos ao longo de sua seqüência: um provável peptídeo de trânsito $\mathrm{N}$-terminal capaz de direcionar a proteína aos cloroplastos; um motivo encontrado em polimerases bacterianas; um sítio de ligação para dinucleotídeos e um sítio de ligação para DNA.

Análises de complementação semelhantes às realizadas por Belanger et al. (1995) foram realizadas por Machado et al. (1997) para demonstrar que o gene thi1 de Arabidopsis thaliana também era capaz de complementar uma linhagem mutante de Saccharomyces cerevisae para o gene em questão, o homólogo de thi1 em leveduras. Um outro dado importante deste trabalho é que as linhagens mutantes no gene THI4 eram mais sensíveis ao tratamento com radiação ultravioleta e metil metanosulfonato (MMS), porém a sensibilidade não se notava na viabilidade dos mutantes e sim na taxa de mutações no DNA mitocondrial e não no nuclear.

Estas observações sugerem uma multifuncionalidade dos produtos de thi1 e THI4 que estão envolvidos na biossíntese de tiamina e na manutenção/estabilidade do genoma organelar, notadamente em mitocôndrias. Dados da literatura revelam ainda que o produto de thi1 pode estar relacionado também à maturação dos frutos, já que em Citrus, este gene foi isolado entre outros cuja expressão é elevada sob a influência de etileno (Jacob-Wilk et al., 1997).

A importância do gene thi1 na viabilidade das plantas é bem retratada nos estudos realizados por Papini-Terzi et al. (2003). O gene thi1 está localizado no cromossomo $\mathrm{V}$ de Arabidopsis thaliana no loco tz (Ribeiro et al., 1996). Um mutante no loco $t z$ apresenta um único polimorfismo em relação ao selvagem: uma transição de $C$ para $T$ que acarreta em uma substituição no resíduo 184 de alanina para valina. Esse resíduo localiza-se em uma região altamente conservada entre eucariotos. Ensaios de complementação com uma estirpe de levedura deficiente na biossíntese de tiamina mostraram que o gene 
mutante é menos eficiente em complementar a ausência de biossíntese de tiamina em relação ao selvagem. Além disso, caso não sejam suplementados com tiamina, os mutantes apresentam cotilédones verdes, mas as folhas verdadeira são brancas e as plantas morrem prematuramente.

Em cana de açúcar, uma busca refinada na base de dados do programa SUCEST ("sugarcane expressed sequence tag") revelou a existência de pelo menos três parálogos desse gene. A presença dessas três isoformas é interessante pois pode sugerir um tipo diferente de regulação gênica quando comparado com Arabidopsis (apresenta uma única cópia do gene)

Além dos casos já descritos acima, o gene thi1 e seus homólogos são amplamente difundidos entre os seres vivos, desde arquebactérias e leveduras até as plantas superiores. Está presente também em algumas espécies de bactérias como Termotoga maritima.

Estudos demonstram que a biossíntese de tiamina em leveduras ocorre nas mitocôndrias. Já em plantas, essa via está provavelmente presente nos plastídeos, o que está de acordo com as características da região $\mathrm{N}$-terminal de THI1 que exibe um peptídeo de trânsito para cloroplastos (Julliard \& Douce, 1991). Uma análise mais detalhada da região $\mathrm{N}$-terminal de THI1 revelou a presença de uma a-hélice anfifílica típica de pré-seqüências mitocondriais. De fato, ensaios utilizando o gene repórter GUS fusionado a diferentes regiões da seqüência de direcionamento de thi1 revelaram que THI1 está presente tanto em cloroplastos quanto em mitocôndrias. Além disso, a análise direta por imunolocalização identificou a proteína THI1 em ambas organelas (Chabregas et al., 2001). 


\subsection{Importação de proteínas para mitocôndrias e cloroplastos}

\subsubsection{Importação de proteínas em mitocôndrias}

Durante a evolução, células eucarióticas desenvolveram um complexo sistema de endomembranas que deu origem a uma grande variedade de compartimentos subcelulares capazes de desempenhar processos fisiológicos e bioquímicos específicos. No caso das mitocôndrias, a origem está relacionada a um evento de endossimbiose do ancestral de uma $\alpha$-proteobactéria. Em plantas, esse sistema tornou-se ainda mais complexo, uma vez que um segundo evento endossimbiótico, no caso, de uma cianobactéria, originou uma importante organela: o plastídio, majoritariamente representado pelos cloroplastos.

O perfeito funcionamento de uma organela depende de seu conteúdo, que é muito bem definido de acordo com as suas funções. Sendo assim, um sistema de importação seletivo e eficiente é fundamental para a manutenção da identidade funcional e estrutural dos diferentes compartimentos subcelulares. Apesar de cloroplastos e mitocôndrias possuírem seus próprios genomas, a maioria das proteínas que eles contêm são codificadas por genes nucleares e precisam ser importadas de seu local de tradução: o citoplasma (Duby \& Boutry, 2002).

Muitas proteínas precursoras mitocondriais sintetizadas no citoplasma são reconhecidas e/ou mantidas em uma forma pouco estruturada, via ação das chaperonas moleculares, e importadas por complexos de translocação presentes nas membranas externa (TOM, "translocase of the mitochondrial outer membrane") e interna (TIM, "translocase of the mitochondrial inner membrane") da mitocôndria. Esses translocons são os responsáveis pelo transporte das proteínas para as diferentes regiões da mitocôndria: membrana externa, espaço intermembrana, membrana interna e matriz mitocondrial (Duby \& Boutry, 2002). 
A maioria das proteínas mitocondriais é reconhecida pelos translocons poe meio de uma seqüência de direcionamento presente normalmente em sua região amino-terminal chamada de pré-seqüência (Duby \& Boutry, 2002).

A eficiência do processo de importação de uma proteína reside nas interações que ocorrem entre a sua pré-seqüência e os aparatos de translocação presentes nas membranas da mitocôndria e no citossol. O mecanismo de importação mitocondrial, melhor estudado em leveduras, parece ser bem conservado entre as espécies, mas, apesar de poucos, os estudos sobre esse processo em plantas deixam claras as diferenças existentes entre fungos, animais e plantas. No caso das plantas, a presença de uma organela adicional, o cloroplasto, que inclusive apresenta mecanismo de importação semelhante, deve ter contribuído para gerar um sistema de importação mais seletivo (Duby \& Boutry, 2002).

Ao longo do processo evolutivo, a maioria dos genes dos genomas organelares foram transferidos para o núcleo e, por isso, o genoma mitocondrial codifica um número limitado de proteínas. A maioria das proteínas residentes na mitocôndria é codificada por genes nucleares, traduzidas no citoplasma em ribossomos livres e importadas para a organela. No caso de Saccharomyces cerevisae estima-se que apenas nove das 400-500 proteínas mitocondriais sejam codificadas pelo genoma da mitocôndria (86 kb) (Foury et al, 1998). Já em Arabidopsis thaliana, cujo genoma mitocondrial (367 kb) é maior do que o da levedura citada acima, cerca de $10 \%$ das proteínas mitocondriais são codificadas pelo genoma organelar (Unseld et al, 1999).

Proteínas importadas para as mitocôndrias são sintetizadas sob a forma de precursores consistindo da proteína madura adicionada de uma préseqüência amino-terminal (majoritariamente) ou carboxi-terminal, que confere a especificidade de importação. As seqüências $\mathrm{N}$-terminais são posteriormente removidas após ou durante a passagem pelo envelope mitocondrial. Proteínas destinadas à membrana externa não apresentam uma seqüência de direcionamento típica, de forma que a informação de direcionamento localiza-se 
na porção interna da estrutura primária. Um exemplo desse último tipo de proteína é o de uma família de carreadores cujo membro mais conhecido é a ADP/ATP translocase (Polcicova et al., 2003). A proteína desacopladora PUMP1 de Arabidopsis thaliana também possui as informações de direcionamento distribuídas ao longo de sua estrutura primária (Sassaki et al., submetido).

O endereçamento das proteínas, porém, é mais complexo do que a simples presença de seqüências de direcionamento. Como no caso da mitocôndria, ele envolve vários subcompartimentos. As proteínas direcionadas para cada um desses subcompartimentos requerem informações de direcionamento específicas e vias de direcionamento que envolvem fatores comuns e distintos a cada etapa (Duby \& Boutry, 2002).

Apesar disso, uma via geral de importação, dividida em quatro etapas pode ser esquematizada: 1) síntese da proteína precursora assim como seu reconhecimento e manutenção de sua conformação adequada para importação ("import-competent") através da atuação de chaperonas moleculares no citoplasma; 2) ligação do precursor a receptores e transporte desse precursor através da membrana externa da mitocôndria pelo complexo TOM; 3) transporte do precursor através do espaço intermembrana e envelope nuclear pelo complexo TIM; 4) processamento proteolítico do precursor, assim como sua distribuição intra-organelar e montagem para aquisição da forma funcional (Duby \& Boutry, 2002).

As chaperonas citoplasmáticas interagem especificamente com as proteínas precursoras mantendo-as em uma conformação adequada para importação e auxiliando no processo de direcionamento e transporte. A atuação das chaperonas é dependente de energia e sua principal função é prevenir a agregação entre proteínas e/ou dobramentos aleatórios que comprometam o transporte através dos complexos de translocação TOM e TIM. Além disso, previne a proteína de atinjir sua conformação final e atividade biológica em um compartimento inapropriado. As chaperonas citoplasmáticas mais conhecidas 
compõem a família Hsp70. Essas proteínas não são específicas para o transporte mitocondrial, mas auxiliam tanto nesse aspecto, que a simples adição de Hsp70 purificada é suficiente para estimular a importação de várias proteínas precursoras em experimentos in vitro (Komiya et al., 1996). Um outro fator que estimula a importação para mitocôndrias foi descrito em mamíferos, mas não em plantas, o MSF ("mitochondrial stimulating factor"), que pertence à família de proteínas 14-3-3 e guia precursores para o receptor Tom70 por meio de um processo ATP-dependente (Komiya et al, 1997). Em plantas, as proteínas 14-3-3 de extrato de gérmem de trigo interagem in vitro com peptídeo de trânsito de cloroplastos e não com pré-seqüências de proteínas mitocondriais (May \& Soll, 2000). Provavelmente, modificações pós traducionais conferem especificidade de importação entre cloroplastos e mitocôndrias.

\subsubsection{Maquinaria de translocação TOM}

Uma vez trazido para a membrana externa, o precursor atravessa essa membrana com a ajuda das proteínas de translocação que compõem o complexo TOM (Figura 1).

O complexo TOM é mais bem estudado em leveduras. Nesse organismo, ele é constituído por nove subunidades: Tom70, Tom71, Tom40, Tom37, Tom20, Tom22, Tom7, Tom6 e Tom5. Essas nove subunidades formam, por sua vez, três subcomplexos hetero-oligoméricos. Dois deles funcionam como receptores para os precursores, Tom20-Tom22 e Tom70/Tom71-Tom37, respectivamente, e um terceiro que forma o poro geral de inserção (GIP "general insertion pore"), constituído pelas proteínas Tom40, Tom22, Tom7, Tom6 e Tom5 (Dekker et al., 1998). 

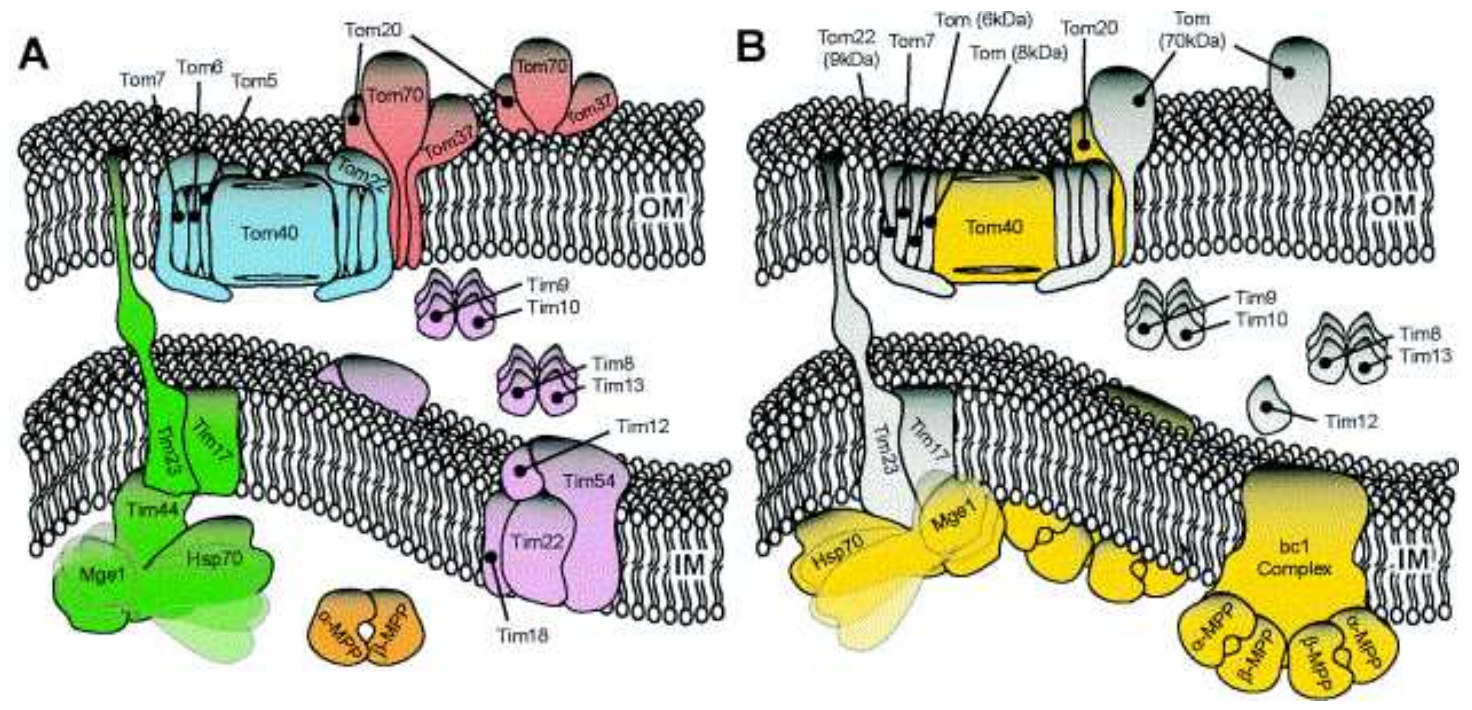

Figura 1 - Representação esquemática do complexo TOM de leveduras (A) e plantas (B)

Modificado de Duby \& Boutry (2002)

Tom20 e Tom22 formam o complexo receptor principal sendo que Tom20 interage com precursores contendo seqüências de direcionamento internas ou no amino terminal, enquanto que Tom22 reconhece especificamente préseqüências amino terminais (van Wilpe et al., 1997). Além disso, Tom22 ancora-se na membrana externa da mitocôndria e forma uma conexão entre os dois subcomplexos hetero-oligoméricos Tom20-Tom22 e Tom70/Tom71-Tom37 (van Wilpe et al., 1999). Já Tom70 e Tom71 são extremamente relacionados e provavelmente exercem funções redundantes (Schlossmann et al, 1996) e junto com Tom37 formam o receptor específico para precursores capazes de se ligar ao MSF (Komiya et al, 1997). Novos relatos da literatura apontam Tom20 como um receptor que reconhece precursores com pré-seqüência amino-terminal e para Tom70 como um receptor que reconhece proteínas mitocondriais que possuem seqüências de direcionamento internas (Endo \& Kohda, 2002). 
Tom40 é o principal componente do GIP, é completamente inserido na membrana externa e forma o canal hidrofílico, cátion-seletivo do complexo TOM (Hill et al., 1998).

Tom5 ancora-se na membrana e uma porção citossólica recebe precursores ligados a receptores presentes no citoplasma, mediando sua inserção no GIP (Dietmeier et al., 1997). Já Tom6 e Tom7 influenciam a interação entre Tom20-Tom22 e Tom40. O primeiro favorecendo as interações e o segundo favorecendo a dissociação formando, assim, um equilíbrio dinâmico que é necessário à importação de proteínas (Alconada et al., 1995; Honlinger et al., 1996).

Em plantas, a identificação de componentes do sistema de translocação da membrana mitocondrial foi caracterizado em duas espécies: Solanum tuberosum (batata) e Arabidopsis thaliana (Jänsch et al., 1988; Werhahn et al., 2001). Em batata, foram identificadas oito subunidades do complexo TOM de 70, 36, 23, 9, 8, 7, e 6 kDa. As subunidades de 36, 23 e 7 kDa são homólogas, respectivamente, de Tom40, Tom20 e Tom7 de leveduras. A proteína Tom22, essencial em leveduras, não foi identificada em plantas, mas a proteína de 9 $\mathrm{kDa}$ possui homologia com Tom22 de levedura em regiões importantes e pode ser que essa proteína desempenhe os papéis de Tom22 em plantas (Macasev et al., 2000).

Em Arabidopsis thaliana, foram identificadas seis proteínas no complexo TOM de 34, 23, 21, 8, 7 e 6 kDa. De acordo com sua seqüência, as proteínas de 34 e 7 kDa são homólogas as Tom40 e Tom7 de leveduras, respectivamente, enquanto que as de 23 e $21 \mathrm{kDa}$ são provavelmente homólogas de Tom20 (Werhahn et al., 2001). Análises de ESTs ("expressed sequence tags") de Arabidopsis thaliana revelam quatro isoformas de Tom20, mas a expressão e função dos produtos desses genes ainda não foram determinadas. Revelam também duas isoformas de Tom22 que parecem ser expressas e são homólogas à proteína de 9 kDa de batata (Macasev et al., 2000). 
A proteína OMP85 possui papel fundamental na inserção de proteínas na membrana de bactérias. Análises comparativas de seqüências sugerem que homólogos de OMP85 estão representados no genoma de eucariotos desde leveduras até humanos, incluindo plantas. Em Saccharomyces cerevisae, Omp85 é essencial para a viabilidade celular e sua ausência prejudica o processo de inserção de proteínas da membrana mitocondrial (Gentle et al., 2004).

Estudos recentes mostram que, além do complexo de translocação TOM, as proteínas da membrana mitocondrial são inseridas com o auxílio de uma maquinaria de seleção e montagem (SAM, "sorting assembly machinery"). Proteínas constituintes da SAM têm sido descritas. Uma delas é a Sam50, que possui domínios conservados desde bactérias até humanos. Leveduras mutantes em Sam50 são deficientes na montagem e inserção da própria Tom40, que forma o poro propriamente dito do complexo TOM (Kozjak et al., 2003). Outra proteína envolvida na SAM é a Mas37 que possui funções de receptor (Wiedemann et al., 2003). O modelo proposto por Wiedemann et al. (2003) é que o complexo TOM não é suficiente para promover a inserção correta de proteínas com topologia sofisticada, como é o caso de Tom40. Nesses casos, o precursor seria transferido para o aparato SAM.

\subsubsection{Maquinaria de translocação TIM}

Dois complexos, TIM 23 e TIM 22, estão envolvidos no processo de translocação dos precursores pela membrana interna das mitocôndrias (Berthold et al, 1995). O complexo TIM 23 é responsável pela importação de precursores contendo sinal de direcionamento para a matriz mitocondrial. Em leveduras, esse complexo é constituído por três subunidades essenciais: Tim17, Tim23 e Tim44. As subunidades Tim17 e Tim23 estão inseridas na membrana interna e funcionam como um canal, enquanto que Tim44 interage com Tim23 do lado da matriz na membrana interna mitocondrial (Ryan et al., 
1998). Juntamente com mt-Hsp70, Mgel (co-chaperone) e consumo de ATP, o complexo TIM23 promove o transporte do precursor através de vários ciclos "liga-desliga" do precursor com mt-Hsp-70. Esse mecanismo pode ser interpretado por meio de um modelo chamado motor molecular (Strub et al., 2000). Em plantas, homólogos de Tim17 e Tim23 já foram encontrados em Arabidopsis thaliana (Bomer et al., 1996), assim como já foi descrito em Nicotiana tabacum uma co-chaperona Grpe1, homólogo de Mge1p, capaz de interagir com mt-Hsp70 (Padidam et al., 1999). Já o complexo TIM22 é responsável pela inserção de carreadores na membrana interna da mitocôndria. Em leveduras é constituído por Tim22, Tim54, Tim18 e Tim12 (Endress et al.,1999). O transporte da família de carreadores através do espaço intermembrana e sua transferência para o complexo TIM22 é mediado por proteínas de baixo peso molecular chamadas: Tim8, Tim9, Tim10, Tim12 e Tim13 (Koehler et al., 1998). Em plantas o complexo TIM22 ainda não foi descrito, mas homólogos estruturais de Tim8, Tim9, Tim10 e Tim13 já foram encontrados no genoma de Arabidopsis thaliana, sugerindo que o complexo TIM22 está presente entre as plantas (Duby \& Boutry, 2002).

Existe ainda uma via de importação semelhante ao sistema de importação através da membrana de bactérias, porém é distinto do aparato clássico envolvendo proteínas Sec. Essa via envolve proteínas Tat ("twin arginine translocation") e reconhece precursores cuja pré-seqüência contém duas argininas geminadas. O sistema Tat já foi descrito em cloroplastos (Wexler et al., 1998) e homólogos dos genes que participam dessa via foram encontrados no genoma mitocondrial de várias plantas superiores (Unseld et al., 1997). Como o genoma mitocondrial normalmente não codifica proteínas para secreção, provavelmente a proteína Tat deve pertencer a um complexo envolvido na exportação para o espaço intermembrana da mitocôndria (Duby \& Boutry, 2002). 


\subsubsection{Processamento de precursores mitocondriais}

Proteínas contendo pré-seqüências $\mathrm{N}$-terminais sofrem maturação depois ou durante sua importação para mitocôndria, mas a inibição das MPPs ("mitochondrial processing peptidase") não impede o transporte (Zwizinski \& Neupert, 1983). Em leveduras, o processamento resulta da atividade de um heterodímero composto pelas subunidades a e $\beta$, sendo que o domínio de ligação ao substrato encontra-se na subunidade a e o sítio catalítico para a reação de clivagem na subunidade $\beta$ (Yang et al., 1988; Luciano et al., 1998; Nagao et al., 2000). Em plantas, as subunidades $\alpha$ e $\beta$ correspondem às proteínas núcleo 1 e núcleo 2 , que por sua vez são duas subunidades do complexo bc1, um componente do aparato respiratório presente na maioria dos eucariotos. O complexo bc1 desenvolve, portanto, duas atividades: peptidase de processamento mitocondrial e compõe o complexo respiratório. Essa dupla função é característica no reino vegetal (Dessi et al., 2000). Uma análise evolucionista revela que entre plantas, animais e leveduras, as plantas refletem a situação mais remota com as duas subunidades da protease de processamento inseridas no complexo respiratório. Em animais e fungos, eventos de duplicação gênica permitiram a separação entre a cadeia respiratória e as atividades de protease, levando à situação encontrada atualmente (Braun \&Schmitz, 1995).

Em leveduras, alguns precursores, como a subunidade IV da citocromo oxidase (Cox IV) e a proteína ferro-enxofre (Fe-S) do complexo bc1, sofrem duas clivagens até atingir sua maturidade. A segunda clivagem é realizada pela peptidase mitocondrial intermediária (MIP), que remove um octapeptídeo depois da remoção do sinal de matriz removido pela MPP (Isaya et al., 1992). Essa segunda clivagem ainda não foi demonstrada em plantas, apesar de já ter sido descrita a presença de um gene putativo de MIP no genoma de Arabidopsis thaliana. Além de MPP e MIP, fungos apresentam também a protease da membrana interna (IMP), responsável pela clivagem de proteínas endereçadas 
para o espaço intermembrana como o citocromo b2 ou membrana interna, como citocromo c1 (Schneider et al., 1994), mas nenhum gene homólogo a essa peptidase foi encontrado em plantas.

\subsubsection{Características estruturais dos precursores da matriz mitocondrial}

Proteínas da matriz mitocondrial são sintetizadas sob a forma de precursores constituídos pela proteína madura e uma pré-seqüência $\mathrm{N}$-terminal ou, menos freqüentemente, C-terminal. Essa pré-seqüência contém a informação de direcionamento para a proteína e atravessa as membranas mitocondriais através dos complexos TOM e TIM. Em seguida, é clivada pelo aparato MPP durante a importação ou uma vez dentro da matriz. Análises de comparação de seqüência e predição estrutural mostram que as préseqüências não possuem uma estrutura primária comum, mas apresentam semelhanças quanto à estrutura secundária. Elas são ricas em resíduos básicos e hidrofóbicos, com alta freqüência de argininas, alaninas, leucinas e serinas, enquanto que sua estrutura assume a forma de uma a-hélice anfifílica (von Heijne, 1986). Em plantas, a pré-seqüência é, em média, nove resíduos mais longos do que em leveduras e contém maior teor de serinas (Shneider et al., 1998). O fato de o aparato de importação mitocondrial ser bastante conservado entre plantas e leveduras provavelmente faz com que as características das pré-seqüências dos precursores importados por eles também sejam semelhantes, mas erros de importação (Hugosson et al., 1995), diferenças entre o padrão de importação in vivo e in vitro (Silva-Filho et al., 1997) e divergências na composição de amino ácidos entre pré-seqüências de leveduras e plantas têm sido descritas (Shneider et al., 1998). A presença de uma organela adicional, os cloroplastos, fez da informação de direcionamento mitocondrial em plantas mais complexa do que em leveduras. Provavelmente este seja o motivo do requerimento por uma pré-seqüência mais longa (Duby \& Boutry, 2002). 
Anfifilicidade e cargas positivas são as duas principais características descritas para a pré-seqüência de precursores mitocondriais e agem em etapas distintas durante a importação. Primeiramente, na superfície da mitocôndria, interações eletrostáticas ocorrem entre as cargas positivas da pré-seqüência e as cargas negativas dos receptores Tom20 e Tom22 (Brix et al., 1997). Em um segundo momento, a pré-seqüência é puxada através da membrana mitocondrial interna seguindo o gradiente de potencial elétrico da membrana (Martin et al., 1991). Pré-seqüências mitocondriais contêm uma grande proporção de aminoácidos hidrofóbicos. Um estudo in vitro na presença de lipossomas usando Tom20 e o precursor da álcool desidrogenase sugere que a hidrofobicidade da pré-seqüência favorece sua interação com a camada bilipídica da membrana (Schleiff et al., 1999). Porém, uma análise estrutural baseada em NMR da ligação de Tom20 de mamíferos a uma pré-seqüência revelou a importância dos resíduos hidrofóbicos nessa interação, pois a préseqüência se liga em um sulco apolar de Tom20 assumindo uma conformação helicoidal que involve interações hidrofóbicas (Abe et al., 2000).

MPP, que é capaz de clivar a pré-seqüência dos precursores, também é capaz de reconhecer uma larga variedade de precursores. Este fato, aliado à ausência de uma similaridade de seqüência em torno do sítio de clivagem, indica que a MPP reconhece elementos estruturais e não a estrutura primária da proteína (Duby \& Boutry, 2002).

\subsubsection{Importação de proteínas para os cloroplastos}

A célula vegetal e seus cloroplastos contêm uma rede integrada que regula a biogênese, diferenciação e função dessas organelas. Esse circuito de comunicação inclui o controle e coordenação da transcrição e tradução em ambos os compartimentos, assim como o controle de importação de proteínas e sua montagem (Soll, 2002). 
Os cloroplastos são as organelas mais complexas em termos de arquitetura, pois possuem seis compartimentos diferentes: membrana interna, membrana externa, espaço intermembranas, estroma, membrana do tilacóide e lúmen do tilacóide (Robinson et al., 1998).

O processo de importação para cloroplastos é altamente regulado. A atividade de receptores de importação é mediada por fosforilação de proteínas, assim como ligação a GTP e hidrólise. A completa translocação para a organela pode depender do seu "status" de potencial redox que é percebido pelos complexos de importação. Uma possibilidade corrente é que, uma vez fosforiladas, proteínas precursoras formam um complexo de importação altamente competente no citossol, mas vários níveis de regulação parecem coexistir (Soll, 2002).

Os cloroplastos importam aproximadamente $95 \%$ das suas proteínas (Abdahllah et al., 2000). A importação ocorre quase sempre após a tradução, pois as proteínas plastidiais são sintetizadas em ribossomos livres. Até que elas estejam em seu local de atuação, com sua conformação correta, são chamadas de precursores. Ou seja, após a tradução, ou durante o processo, o precursor liga-se a fatores citossólicos antes de se ligar ao envelope nuclear e ser translocado através dele. Essa interação com proteínas citossólicas, muitas delas chaperonas pertencentes à família $H s p 70$, previne o dobramento espontâneo do precursor, o que comprometeria sua passagem pelo complexo de importação, e direciona o precursor para esse complexo de importação, através de interação com os seus componentes (Wu et al., 1994).

Muitas proteínas são sintetizadas com seqüências de direcionamento cliváveis em sua região amino terminal (pré-seqüência ou peptídeo de trânsito) que são as responsáveis pelo direcionamento e translocação (Rensink et al., 2000). 


\subsubsection{Direcionamento de proteínas aos envelopes externo e interno}

O reconhecimento específico dos precursores e seu transporte através da membrana externa do cloroplasto se dá por meio de um complexo molecular hetero oligomérico chamado TOC ("translocon at the outer envelope of chloroplast") (Figura 2). O complexo TOC opera em conjunto com o complexo TIC ("translocon at the inner envelope of the chloroplast") para facilitar a passagem de polipeptídeos através de ambas as membranas. A pré-seqüência é clivada por uma protease do estroma para liberar a proteína madura. Todo esse processo é dependente de energia e involve a hidrólise de nucleosídeos trifosfatados, tanto no envelope externo, quanto no espaço intermembrana e estroma (Jarvis \& Soll, 2001 citado por Soll, 2002).

A translocação começa no citosol e essa é a primeira oportunidade para regulação. A maioria das proteínas plastidiais podem ser fosforiladas em um resíduo específico de serina ou treonina presente em sua pré-seqüência (por exemplo, pequena subunidade da rubisco, LHCB, subunidades de 22 e 33kDa do complexo envolvido com oxigênio, hcf136, clorofila a oxigenase e subunidade $\gamma$ da ATPase) (Waegemann \& Soll, 1996; May \&Soll, 2000).

O contexto de aminoácidos em torno desses sítios de fosforilação é conservado entre precursores de cloroplastos e está fortemente relacionado ao motivo de ligação às proteínas 14-3-3. O modelo geral sugere que, uma vez fosforilada, a proteína precursora liga-se a 14-3-3 e a uma proteína da família Hsp 70 (e talvez outras proteínas ainda não identificadas) formando um complexo hetero oligomérico. Os precursores que formam esse complexo são importados em uma velocidade quatro a cinco vezes maior do que as monoméricas. A etapa de fosforilação pode, portanto, significar a inclusão da proteína fosforilada em uma rota mais rápida de importação, enquanto que as não fosforiladas são importadas em baixa prioridade. Além disso, a fosforilação pode causar uma conformação da pré-seqüência mais apropriada para o 
reconhecimento do complexo de importação (May \& Soll, 2000; Schleiff et al., 2002).

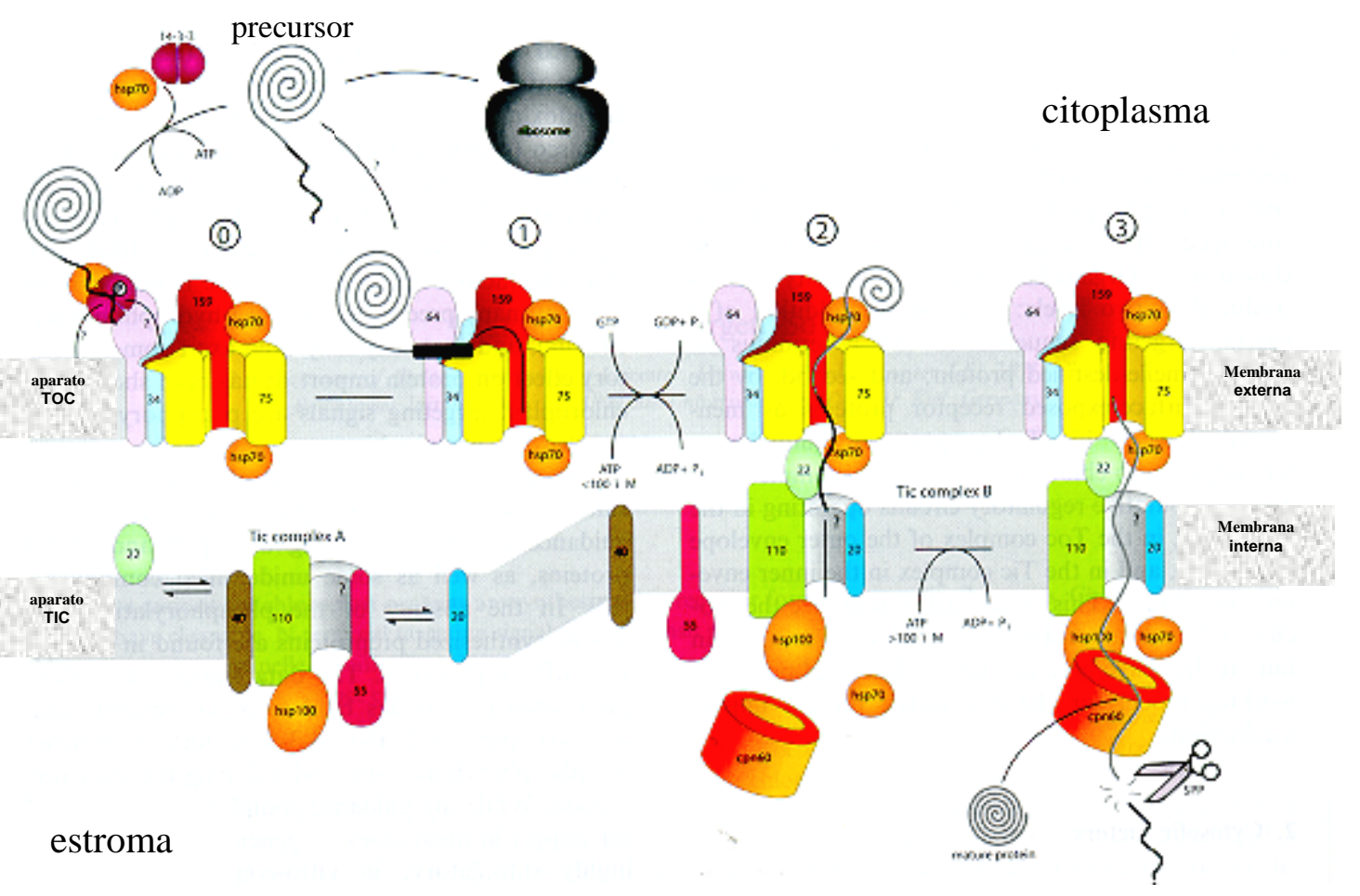

Figura 2- Mecanismo molecular de importação através das membranas externas e internas do cloroplasto

Modificada de Jarvis \& Soll (2001)

Uma segunda oportunidade de regulação está no reconhecimento e iniciação da translocação da proteína no complexo TOC. Em ervilha quatro diferentes subunidades do complexo TOC foram identificadas: Toc159, Toc75, Toc64 e Toc34. Em Arabidopsis thaliana, as principais subunidades do complexo TOC pertencem a pequenas famílias gênicas (Jackson-Constan \& Keegstra, 2001). Sendo assim, a família Toc159 engloba Toc132, Toc120 e 
Toc90. Esses três membros possuem papéis parcialmente redundantes, mas não são capazes de suprir a falta de Toc159 (Hiltbrunner et al., 2001). Células do mesofilo contêm um estoque solúvel de Toc159. Essa presença pode indicar que Toc159 funciona como uma lançadeira (pegando proteínas precursoras no citoplasma e levando-as para o complexo de translocação da membrana do envelope plastidial) ou então que se constitui em uma reserva para o consumo de Toc159 (Hiltbrunner et al., 2001).

Toc75 constitui o poro propriamente dito do translocon formando um canal com 16 folhas $\beta$-pregueada inseridas na membrana, com propriedades cátion-seletivas. Em plantas, já foram descritos Toc75III e Toc75V (Eckart et al., 2002). O Toc75V assemelha-se mais ao homólogo procarioto e deve ter papel na importação de uma determinada subclasse de proteínas precursoras como, por exemplo, a Tic22 que exibe características especiais de importação (Kouranov et al., 1999).

Toc64 expõe três repetições de um peptídio tetra-trico na superfície da organela e pode estar envolvido com a captação do complexo de direcionamento na superfície do cloroplasto (Sohrt \& Soll, 2000). Toc64 tem características semelhantes a Tom70, presente em mitocôndrias (Pfanner \&Geissler, 2001).

Toc34 é um segundo receptor de precursores (Schleiff et al., 2002) e tem mais afinidade pelos precursores fosforilados (Jelic et al., 2002). Toc159 e Toc34 são as mais proeminentes fosfoproteínas no envelope externo dos cloroplastos e são fosforiladas por duas quinases distintas. O evento de fosforilação pode alterar a conformação de Toc159 e Toc34 (Fulgosi \& Soll, 2002). As duas proteínas têm habilidade de ligar a GTP em sítios bastante parecidos entre as duas proteínas (Kessler et al., 1994). Toc159 tem um segundo sítio de ligação a nucleotídeo específico para ATP (Hirsh et al., 1994). Toc34 atua em conjunto com Toc75, tem a capacidade de se dimerizar e funcionar como seu próprio ativador GTPásico (Sun et al., 2002). A translocação através do complexo TIC constitui uma terceira oportunidade para 
regulação e ocorre juntamente com a do complexo TOC (Alefsen et al., 1994). Esse transporte requer altas concentrações de ATP, que deve ser necessário à ação de chaperonas moleculares da família hsp70 ou hsp100 ou ambos, que "puxam" o precursor através do translocon (Kessler \& Blobel, 1996; Akita et al., 1997). O TIC é constituído de várias subunidades: Tic110, Tic62, Tic55, Tic40, Tic22 e Tic20.

Tic110 está sempre associada ao complexo TOC. Experimentos de copurificação sugerem que ela forma uma junção física ao complexo TOC. Do lado do estroma, Tic110 associa-se a chaperonas moleculares da família Hsp100 e/ou chaperoninas 60. Essa associação pode ocorrer via Tic40, mas já foi demonstrada a capacidade de Tic110 em reconhecer precursores de acordo com seu peptídeo de trânsito e formar um canal cátion seletivo (Lübeck et al., 1996).

Tic62 normalmente é isolada com Tic110 e Tic55 e possui alta homologia com NADPH desidrogenase. No seu carboxi terminal (virado para o estroma), Tic62 expõe um motivo que interage especificamente com ferredoxina e NADP redutase, enzima que acopla o fluxo fotossintético de elétrons à redução de NADPH. Tic62 pode, então, funcionar como um sensor redox ou de formas oxidadas ou reduzidas de NADPH (Küchler et al., 2002).

Tic55 é um outro candidato a sensor redox, pois contém um motivo do tipo Rieske com núcleo de Fe-S e um sítio de ligação a ferro mononuclear (Caliebe et al., 1997). Estudos com duas diferentes isoformas de ferredoxina, Fdl e Fdlll, e ferredoxina NADP redutase reforçam a hipótese de que o transporte pela membrana dos cloroplastos é controlado pelo estado redox. Fdlll é expressa constitutivamente em níveis baixos e Fdl é altamente induzida por luz e, por isso, é considerada a forma fotossintética. Na presença de luz, apenas Fdl é corretamente importada para o estroma, enquanto que Fdlll é perdida no espaço intermembrana. No escuro, ambas são corretamente levadas ao estroma (Hirohashi et al., 2001). 
Tic40 deve funcionar como recrutador de chaperonas moleculares devido a sua homologia de seqüência com proteínas que possuem esta função (Stahl et al., 1999). Além disso, é indispensável para a viabilidade da célula (Budziszewski et al., 2001).

Tic 22 está ligada ao complexo TIC do lado do espaço intermembrana, mas seu papel não é claro (Kouranov et al., 1998). Tic20, é uma proteína integral semelhante a Tim17 de mitocôndria e deve fazer parte do canal de translocação.

A maioria das proteínas do envelope interno é sintetizada sob a forma de precursores com seqüências de direcionamento cliváveis na região amino terminal e são importadas em condições semelhantes às proteínas do estroma (Soll, 2002). Por outro lado, as proteínas do envelope externo apresentam, em sua maioria, sinais internos de direcionamento não cliváveis, com exceção de Toc75 (Inoue et al., 2001). OEP7 de espinafre, seu homólogo de ervilha OM14 e Toc34 são os casos mais bem conhecidos de proteínas inseridas no envelope externo sem pré-seqüência (Schleiff et al, 2001).

\subsubsection{Transporte de proteínas ao estroma e tilacóides}

As proteínas residentes na membrana e no lúmem dos tilacóides requerem um nível mais complexo de transporte, pois envolvem a passagem através de diferentes compartimentos (Robinson et al., 1998). As proteínas mais bem conhecidas são a plastocianina e as proteínas de 33, 23 e 16 kDa do PSII (fotossistema II) e são transportadas em um mecanismo que envolve duas etapas: primeiro, são transportadas para o estroma e, depois, para o lúmem dos tilacóides (James et al., 1989). A ocorrência dessas duas etapas é possível porque as proteínas importadas para o lúmem dos tilacóides são sintetizadas sob a forma de precursores contendo um duplo sinal de direcionamento: um que endereça para o estroma (hidrofílicas, básicas e ricas em resíduos hidroxilados) e outro que endereça para o lúmem (domínio $\mathrm{N}$-terminal 
carregado, core hidrofóbico e domínio polar terminando com resíduos que contenham grupamentos pequenos como, por exemplo, alanina). Na primeira fase do transporte, a pré-seqüência é clivada por uma peptidase do estroma SPP ("stromal processing peptidase"). Uma segunda clivagem no lúmem do tilacóide, feita pela TPP ("thylakoidal processing peptidase"), leva à proteína madura (Bassham et al., 1991; van der Vere et al. 1995). TPP faz parte de uma família de peptidases de sinal bastante semelhante às presentes em bactérias (Chaal et al., 1998). Esse fato levantou a hipótese de que a membrana dos tilacóides fosse dotada de um aparato de importação semelhante ao sistema Sec de eucariotos, o que é uma hipótese bastante compatível com a origem endosimbionte dos cloroplastos (Yuan et al., 1995). De fato, as proteínas residentes do lúmem dos tilacóides são endereçadas a partir do estroma por meio de duas vias. Um conjunto é importado através do sistema Sec, dependente de ATP, e outro conjunto o faz por meio de um sistema $\Delta \mathrm{pH}$ dependente, ATP independente (Cline et al., 1992). Os peptídeos de trânsito presentes em cada conjunto de proteínas exibem características próprias que conferem a especificidade pelo sistema de transporte (Chaddock et al., 1995).

Os tilacóides possuem várias proteínas de membrana integrais, muitas delas contendo inclusive múltiplas regiões embebidas na membrana. Porém, pouco se sabe a respeito dos mecanismos de inserção dessas proteínas e muito do que se sabe advém do estudo da LHCP ("light-harvesting chlorophyllbinding protein") do PSII. Estudos iniciais mostram que, mesmo quando a seqüência de direcionamento original da LHCP é trocada ou retirada, ela continua inserindo-se normalmente na membrana do tilacóide. Esse fato sugere que a informação necessária para o evento de inserção está na proteína madura (Lamppa, 1988). Ensaios de reconstituição in vitro mostraram que a inserção requer nucleosídeos trifosfatados e, pelo menos, um fator estromal chamado de SRP ("signal recognition particle"). Esse fator forma um complexo com a LHCP que facilita a sua inserção na membrana do tilacóide (DeLille et al., 2000). 
Um outro mecanismo de inserção na membrana tilacoidial é o do citocromo $f$, codificado pelo genoma do cloroplasto e um dos constituintes do complexo de citocromo bf. Durante o processo de tradução, as cadeias nascentes do citocromo $f$ interagem fortemente com a proteína cpSecA que por sua vez faz parte do translocon Sec. O processo de inserção é co-traducional, depende de uma seqüência de direcionamento $\mathrm{N}$-terminal que é reconhecida pelo complexo Sec e a translocação do citocromo $f$ cessa em uma região na porção C-terminal que forma uma âncora na membrana do tilacóide (Rohl \& van Wijk, 2001).

Existem ainda casos de inserção espontânea. É o caso da proteína $C F_{0}$ ll (subunidade II da ATP sintase), que possui seqüência de direcionamento bipartida como várias outras proteínas tilacoidiais, mas insere-se na membrana por processos que independem dos aparatos de inserção conhecidos (Michl et al., 1994). Outras proteínas como PsbX, PsbW e PsbY exibem o mesmo comportamento (Tissier et al., 2002).

Um outro sistema atuante na inserção de proteínas nas membranas dos tilacóides é o $\Delta \mathrm{pH}$-Tat ("twin arginin translocon"), também presente em bactérias e provavelmente oriúndo de um ancestral remoto procarioto. Ele é totalmente dependente de um gradiente de $\mathrm{pH}$ através da membrana na qual o precursor deve ser inserido. Esse precursor deve ter em seu peptídeo de transito dois resíduos de arginina conservados (Dabney-Smith et al., 2003).

\subsection{Duplo direcionamento}

A biogênese das organelas e manutenção das funções celulares em sistemas multicompartimentalizados requerem mecanismos de importação eficientes que asseguram o endereçamento correto das proteínas para seu destino final. Um número crescente de trabalhos tem mostrado que várias proteínas são endereçadas simultaneamente para mais de um compartimento, 
já que algumas funções estão presentes em mais de um compartimento. No caso de plantas, o sistema de translocação atingiu o grau máximo de especialização e alto nível de complexidade devido à aquisição e desenvolvimento de um compartimento adicional: os plastídeos (Silva-Filho, 2003).

De maneira geral, as proteínas que necessitam ser enviadas a mais de um compartimento subcelular, são, em sua grande maioria, resultado de um processo de duplicação gênica, sendo que cada produto é equipado com uma seqüência de direcionamento distinta. Entretanto, em algumas situações, este processo pode ser assegurado a partir da produção de produtos distintos de um mesmo gene que carregam informações específicas a respeito de sua localização. Os mecanismos moleculares que permitem o duplo direcionamento de uma proteína ainda não estão completamente elucidados, mas envolvem estratégias de controle que ocorrem nas etapas de transcrição (início da transcrição em diferentes sítios ou processamento alternativo), tradução (sítios alternativos de tradução) e pós tradução (seqüências de direcionamento ambíguas, modificações pós traducionais e importação competitiva) (Silva-Filho, 2003) (Figura 3).

A enzima monodehidroascorbato redutase (MDAR) de Arabidopsis thaliana reside em cloroplastos e mitocôndrias. Análises utilizando a técnica de transcrição reversa revelaram que dois sítios distintos de início de transcrição geram RNAs mensageiros com extremidades 5' diferentes que, por sua vez, são traduzidos em seqüências de direcionamento com características típicas de cloroplastos e mitocôndrias (Obara et al., 2002).

Um outro caso bastante interessante envolvendo controle durante a etapa de transcrição é o de uma enzima de feijão que atua na biossíntese de amido. Hamada et al. (2002) demonstraram que a PvSBE2 está presente na fração solúvel e no grânulo de amido. Por meio de técnicas como transcrição reversa e 5' RACE (amplificação rápida de extremidades de cDNA), foi 
descoberto que as duas isoformas são geradas a partir de sítios alternativos de "splicing" no transcrito primário.

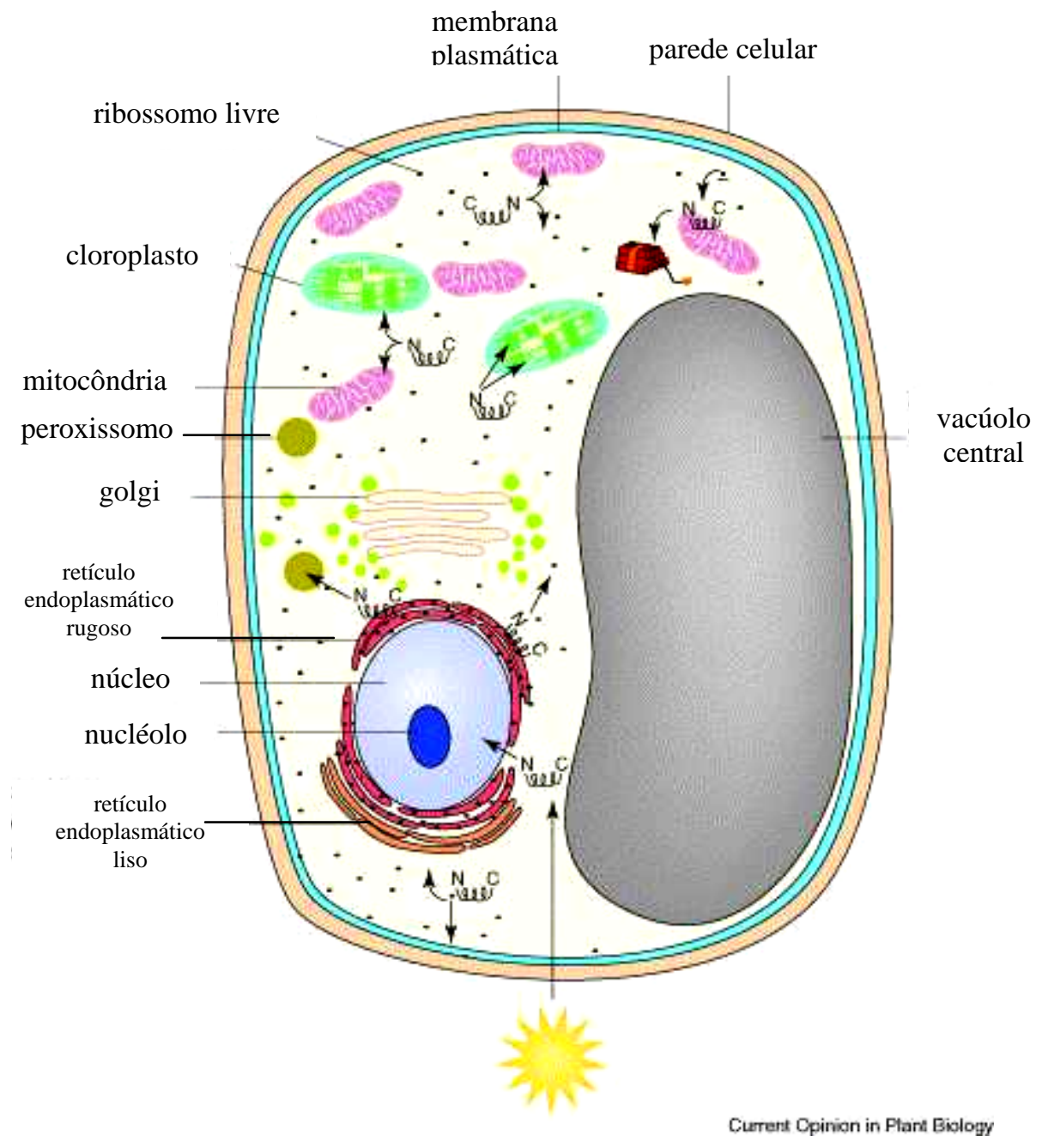

Figura 3 - Representação esquemática de duplo direcionamento de produtos de genes de cópia única

Modificado de Silva-Filho (2003) 
Além dos mecanismos transcricionais, existem os traducionais. $O$ principal deles envolve a iniciação da tradução em códons alternativos. É o que acontece com a proteína THI1 de Arabidopsis thaliana. THI1 possui dois códons de iniciação na mesma fase de leitura sendo que a tradução a partir do primeiro códon dá origem a um produto que é direcionado para os cloroplastos. A tradução a partir do segundo códon origina uma proteína que é direcionada às mitocôndrias. De fato, experimentos de tradução in vitro demonstram que o contexto em torno do segundo códon é menos favorável, mas é capaz de permitir o início da tradução. Além disso, análises de expressão transiente em protoplastos de tabaco, usando construções fusionadas a GFP em que a seqüência de direcionamento de THI1 foi mutada ora no primeiro AUG ora no segundo AUG, comprovam que a proteína é importada tanto para mitocôndrias quanto para cloroplastos (Chabregas et al., 2003).

Já a proteína adenilato quinase (Adk1p/Aky2p) de leveduras sofre um outro mecanismo de direcionamento que proporciona a sua manutenção tanto no citoplasma quanto em mitocôndrias. Uma vez sintetizada, Adk1p/Aky2p assume sua conformação ativa espontaneamente sem o auxílio de chaperonas. Essa conformação, porém, inviabiliza seu transporte para a mitocôndria. As moléculas de Adk1p/Aky2p, que são importadas para a mitocôndria, interagem com os receptores mitocondriais antes que a tradução se complete e a proteína assuma sua conformação ativa. Esse é um caso típico de importação competitiva (Strobel et al., 2002)

Alguns dos mais importantes mecanismos de direcionamento que regulam o duplo direcionamento de proteínas estão relacionados à regulação pós-traducional. Essa regulação envolve sinais internos e externos como: luz, mudanças metabólicas, prenilação e estresse, entre outros. Assim sendo, a localização final de uma proteína pode ser influenciada por fatores extrínsicos a sua seqüência primária (Silva-Filho 2003) (Figura 3).

No caso do fotoreceptor fototropina, normalmente localizado na membrana plasmática, a localização subcelular é sensível à qualidade da luz. 
Esse fotoreceptor está envolvido no fototropismo, expansão foliar, movimento de cloroplastos e abertura estomatal. Além disso, tem função de quinase e sofre autofosforilação na presença de luz azul. Plantas de Arabidopsis thaliana expressando construções gênicas em que a seqüência codificadora da fototroina foi fundida a GFP demonstram que, em presença de luz azul, a fototropina desloca-se para o citoplasma (Sakamoto \& Briggs, 2002).

Modificações pós traducionais, como a prenilação, também podem influenciar a localização subcelular de uma proteína. É o exemplo da calmodulina CaM53 de planta que, em seu estado prenilado, associa-se à membrana e, quando não prenilada, localiza-se no núcleo. A proteína CaM53 pemanece no núcleo em situações de bloqueio da síntese de isoprenóides, o que ocorre quando as plantas são submetidas a longos períodos de escuro e começam a faltar fontes de carbono. Quando essas mesmas plantas são colocadas na presença de sacarose $2 \%$, a prenilação se reestabelece e CaM53 volta a se ancorar na membrana. A localização subcelular de CaM53 está profundamente relacionada ao estado metabólico da planta (RodriguezConcepcion et al., 1999).

Freqüentemente, os casos de duplo direcionamento de produtos de genes de cópia única são relatos de proteínas que vão para mitocôndrias e cloroplastos. Apesar de possuírem genomas próprios, a maior parte das proteínas dessas organelas são codificadas por genes nucleares e importadas para seu destino final. Porém, essas duas organelas apresentam várias funções em comum, como replicação do DNA, transcrição, tradução e proteção contra estresse oxidativo. O duplo direcionamento seria uma forma "econômica" de endereçar proteínas com a mesma função ou mesmo com funções diferentes em cada compartimento (Silva-Filho, 2003). Estudos filogenéticos indicam que as mitocôndrias surgiram antes dos cloroplastos ao longo do processo evolutivo e esse fato pode ter facilitado a incorporação do aparato pré-existente de translocação mitocondrial pelos recém chegados plastídeos (Peeters \& Small, 2001). 
A grande maioria das proteínas que apresentam duplo direcionamento para mitocôndrias e cloroplastos possuem seqüências de direcionamento ambíguas. Um caso bastante estudado é o da glutationa redutase de ervilha que exibe domínios separados de importação para mitocôndria e cloroplasto em sua seqüência de direcionamento (Rudhe et al., 2002). 


\section{MATERIAL E MÉTODOS}

\subsection{Endereçamento da proteína THI1 de Arabidopsis thaliana}

\subsubsection{Cassetes de expressão}

Com a finalidade de transformar plantas de Arabidopsis thaliana com construções gênicas contendo a THI1 completa ou apenas sua seqüência de direcionamento, que abrange os primeiros 105 aminoácidos da proteína, fundidas a smGFP ("soluble modified green fluorescet protein"), foram construídos os cassetes de expressão esquematizados na Figura 4.

Os fragmentos de DNA utilizados nas construções gênicas correspondentes ao promotor do thi1, à seqüência codificadora de THI1 e ao gene da GFP foram amplificados a partir dos plasmídeos pGEM+Pr4 (Farias, 2001), pBSK+THI1 (Machado et al., 1996) e pBC+GFP (Davis \& Viestra, 1998), respectivamente.

A construção de uma proteína quimérica constituída por THI1+GFP foi obtida por meio da clonagem das duas seqüências codificadoras na mesma fase de leitura. Para isso, foram desenhados iniciadores com características especiais (Figura 5). O códon de terminação de THI1 foi deletado durante a amplificação do fragmento e um sítio de $X b a$ I foi introduzido nas extremidades $3^{\prime}$ de thi1 e $5^{\prime}$ do gene da GFP. Apenas dois aminoácidos adicionais, não presentes originalmente em nenhuma das duas proteínas, foram incorporados: uma serina

e

uma

arginina. 
1

\begin{tabular}{|l|l|l|l|}
\hline promotor THI1 & THI1 & smGFP nos \\
\hline
\end{tabular}

2

\begin{tabular}{|l|l|l|l|}
\hline promotor THI1 & Seq. Dir. THI1 & SmGFP & nos \\
\hline
\end{tabular}

3

$$
35 S
$$

THI1

SmGFP

nos

4

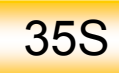

Seq. Dir. THI1

SmGFP

nos

Figura 4 - Esquema dos cassetes de expressão utilizados na transformação de Arabidopsis thaliana. 1- Promotor de thi1 comandando a expressão da THI1 completa fundida a smGFP+terminador nos. 2- Promotor de thi1 comandando a expressão da seqüência de direcionamento de THI1 fundida a smGFP+terminador nos. 3- Promotor de $35 \mathrm{~S}$ comandando a expressão de THI1 completa fundida a smGFP+terminador nos. 4- Promotor de $35 S$ comandando a expressão da seqüência de direcionamento de THI1 fundida a smGFP+terminador nos

\subsubsection{Seqüenciamento das regiões de ligação do fragmento thi1 ao vetor pBSK}

Para confirmação da seqüência nas regiões de ligação do plasmídeo ao fragmento thi1, informação essencial para o desenho dos oligonucleotídeos iniciadores e para verificar a integridade das extremidades, o plasmídio $\mathrm{pBSK}^{-}$ 
+THI1 foi utilizado como molde em reações de seqüenciamento nas quais foram usados os oligonucleotídeos iniciadores universais "forward" e "reverse" (Figura 6). As reações de sequenciamento foram realizadas em sequenciador automático ( $\mathrm{ABI}$ PRISM 377), utilizando-se o "Perkin-Elmer ABI-Prism BigDye ${ }^{\mathrm{TM}}$ Terminator Cycle Sequencing Ready Reaction Kit”, segundo instruções do fabricante.

\subsubsection{Amplificação dos fragmentos de DNA correspondentes às seqüências do promotor $35 \mathrm{~S}$ e às regiões codificadoras das proteínas THI1 e GFP}

Os oligonucleotídeos iniciadores utilizados nessas amplificações (Figura 5) foram desenhados com base nas seqüências já disponíveis em bancos de dados ou obtidas no seqüenciamento descrito anteriormente (Figura 6).

As reações de amplificação foram conduzidas em termociclador PTC$100^{\mathrm{TM}}$ Programmable Thermal Controller MJ Research com incubação inicial de 1:30 min a $94{ }^{\circ} \mathrm{C}$, seguido por 30 ciclos consecutivos de $94{ }^{\circ} \mathrm{C}$, por $30 \mathrm{~s}$, para desnaturação, $50{ }^{\circ} \mathrm{C}$, por $1 \mathrm{~min}$, para hibridação e extensão por 1:30 min a 72 ${ }^{\circ} \mathrm{C}$. Após os ciclos, as reações foram submetidas a um período adicional de polimerização de $10 \mathrm{~min}$ a $72{ }^{\circ} \mathrm{C}$. Cada reação continha 30 a $50 \mathrm{ng}$ de DNA plasmidial, 2 unidades de Pfu polimerase (Promega) e 30 pmoles dos oligonucleotideos em um volume final de $50 \mu \mathrm{L}$. A estimativa do tamanho dos produtos de amplificação por eletroforese em géis de agarose $1 \%$, clonagem e seqüenciamento do produto amplificado confirmaram a identidade do fragmento. 


\subsubsection{Obtenção do fragmento Pr4 correspondente ao promotor de thi1}

Para obtenção do fragmento Pr4, correspondente ao promotor original de thi1 em Arabidopsis thaliana, o clone pGEM+Pr4 foi digerido com EcoR I, liberando um fragmento de $1,2 \mathrm{Kpb}$, referente ao promotor. Os produtos das digestões enzimáticas foram separados em gel de agarose $1 \%$ e o fragmento de interesse foi excisado do gel e purificado com QIAEX II Gel Extraction Kit, conforme especificações do fabricante. O DNA purificado foi eluído em $\mathrm{H}_{2} \mathrm{O}$ deionizada autoclavada e armazenado a $-20^{\circ} \mathrm{C}$.

\subsubsection{Clonagem dos fragmentos em vetor $\mathrm{pBSK}^{-}$}

Após a obtenção dos fragmentos por meio de PCR, digestão e posterior dessalinização, estes foram submetidos à digestão por $3 \mathrm{~h}$ a $37^{\circ} \mathrm{C}$ com $7 \mathrm{U}$ de cada uma das enzimas com sítios de restrição em suas extremidades. Os fragmentos foram novamente dessalinizados, ressuspendidos em $\mathrm{H}_{2} \mathrm{O}$ deionizada autoclavada e utilizados em reações de ligação.

Paralelamente, uma amostra de vetor $\mathrm{pBSK}^{-}$(Stratagene) foi digerida com $15 \mathrm{U}$ das enzimas de restrição Xba I e BamH I durante $3 \mathrm{~h}$ em reações independentes, para a criação de extremidades coesivas às extremidades da seqüência codificadora de thi1 e sua seqüência de direcionamento. Após a digestão, o vetor foi separado em gel de agarose $1 \%$ e a forma linearizada foi excisada do gel e purificada com QIAEX II Gel Extraction Kit, conforme especificações do fabricante. 
1) 5' CCC GGA TCC ATG GCT GCC ATA GC 3'

2) 5' GGG TCT AGA AGC ATC TAC GGT TTC AGC 3'

3) 5' CCC GGA TCC ATG GCT GCC ATA GC 3'

4) 5' CCC TCT AGA GTT CTT ACT GAT CTC 3'

5) 5' CCC TCT AGA ATG AGT AAA GGA G 3'

6) 5' GAT CAT GCG AGC GGC CGC CTG CAG GTC AAT 3'

7) 5' CCC CTC GAG CAA GCT TGG CAC 3'

8) 5' GGG GAA TTC GTC AAG AGT C 3'

Figura 5 - Oligonucleotídeos utilizados na amplificação da seqüência codificadora de THI1 (1 e 2), da seqüência de direcionamento de THI1 (3 e 4), da seqüência codificadora de smGFP adicionada do terminador nos (5 e 6 ) e do promotor $35 \mathrm{~S}$ ( 7 e 8). Em azul, os sítios das enzimas de restrição de Bam HI (1 e 3), Xba I (2, 4 e 5), Notl (6), Xhol (7) e EcoR I (8). Os códons de iniciação das proteínas estão em vermelho 


\section{A}

AGGGCGAATTGGAGCTCCACCCGCGGTGGCGGCCGCTCTAGAACTAGTGGATCCCCCGGG CTGCAGGAATTCCTCGAGCTACGTCAGGGTTTTTTTTTAACGAGAACATACGCATTACGA ATGAACGGATACGATATTTTACACAGAAGTTCAGAAGAGAGAAACAAAGACACCAGAAAA GTTCAAGACATATTAAACACCTAAACTCCTTTTATTGCACTCCTTCAACATCCGAAGGAT CAAGGGAAACTTTTCTTAACGTTAAAACCTTTTGATTTTAAGCATCTACGGTTTCAGCTG AATCTGCTGCGGCTAAGACCAGCTCCGGGCTTAGGTTTCCAACGAGAGTTCCGTCAATAG CATTCGGTAGCCCCAAAGCCTTAAGAGCAAGTTGTCCCGCCTTTTGTCCCGATATCATCA TAGCACCAAAAGTTGGTCCCATTCTCGGNGCACCATCGATCTCAGCAACTTCATACCGGT AACAATCATACCAAGGAACAACCT

\section{B}

TTTGACGCCCGTTCGAAATTCCCCTCACTAAAGGGAACAAAAGCTGGTACCGGGCCCCC CCTCGAGGTCGACGGTATCGATAAGCTTGATATCGAATTCCTCGAGCTACGTCAGGGGA AAAACAAAAATGGCTGCCATAGCTTCTACTCTCTCTCTTTCTTCAACCAAACCTCAGAG ACTTTTCGATTCTTCCTTCCATGGCTCAGCCATCTCCGCAGCTCCTATCTCCATCGGTC TCAAACCACGATCTTTCTCCGTTCGCGCCACAACCGCTGGTTACGACTTGAACGCTTTC ACGTTCGACCCGATCAAGGAATCGATCGTGTCACGTGAGATGACGAGAAGGTACATGAC GGATATGATCACTTATGCTGAGACTGATGTCGTCGTCGTTGGTGCTGGATCTGCTGGTT TATCTGCTGCTTATGAGATCAGTAAGAACCCTAATGTTCAAGTTGCCATTATTGAGCAA TCTGTTAGTCCTGGTGGTGGTGCTTGGCTCGGTGGTCAGCTTTTCTCCGCCATGATTGG TCGCAAACCAGCTCACTTGTT

Figura 6 - Seqüenciamento das regiões de junção entre o vetor pBSK e a seqüência codificadora de THI1. A - seqüência obtida por meio da extensão do iniciador universal "forward" e B - seqüência obtida por meio da extensão do iniciador universal "reverse". Em vermelho, sítio de início da proteína THI1; em azul, segunda metionina e início da seqüência de direcionamento para mitocôndria 
As reações de ligação do fragmento de DNA correspondente à região codificadora do gene thi1 e sua seqüência de direcionamento ao vetor pBSK$^{-}$ foram conduzidas de acordo com técnicas padrão de clonagem molecular em plasmídios (Sambrook et al., 2001). Os fragmentos de DNA a serem clonados e o vetor foram utilizados na relação molar 3:1, em um volume final de $15 \mu \mathrm{L}$, em presença de $1 \mathrm{U}$ da enzima T4 DNA Ligase (Invitrogen), Tris- $\mathrm{HCl} 50$ $\mathrm{mmol} / \mathrm{L}, \mathrm{pH} 7,5, \mathrm{MgCl}_{2} 7 \mathrm{mmol} / \mathrm{L}$, DTT (ditiotreitol) $1 \mathrm{mmol} / \mathrm{L}$. As reações foram incubadas a $16{ }^{\circ} \mathrm{C}$ por 12 horas. Após o período de incubação, $7 \mu \mathrm{L}$ da reação de ligação foram usados para transformar $150 \mu \mathrm{L}$ de células competentes Escherichia coli JM109 preparadas conforme descrito anteriormente. As bactérias transformadas foram plaqueadas em LB sólido contendo ampicilina $100 \mu \mathrm{g} / \mathrm{mL}$, X-gal e IPTG e crescidas durante $12 \mathrm{~h}$ a $37^{\circ} \mathrm{C}$. As bactérias recombinantes e as transformadas foram selecionadas pela coloração da colônia e resistência à ampicilina, respectivamente.

Esse procedimento gerou os plasmídeos pBSK + THI1 e pBSK +seq.dir. Esses dois plasmídeos foram digeridos com EcoR / e utilizados como vetor em reações de ligação cujo inserto foi o fragmento Pr4, correspondente ao promotor do gene thi1 de Arabidopsis thaliana. Nesse caso, a enzima Hind III, com sítio de restrição no promotor Pr4 e na seqüência codificadora de THI1, foi utilizada para diagnosticar a orientação do promotor. Desta forma foram obtidos os plasmídeos pBSK + +Pr4+THI1 e pBSK+Pr4+seq.dir. Já no caso dos cassetes de expressão contendo o promotor 35S, os plasmídeos pBSK ${ }^{-}+\mathrm{THI}^{1}$ e pBSK${ }^{-}$ +seq.dir foram digeridos com Xho I e EcoR I e utilizados como vetor em reações de ligação cujo inserto foi o fragmento 35S. Desta forma foram obtidos os plasmídeos pBSK $+35 S+T H I-1$ e pBSK+35S+seq.dir.

Os plasmídeos pBSK-Pr4+THI1, pBSK-Pr4+seq.dir, pBSK+35S+THI-1 e pBSK-35S+seq.dir foram digeridos com Xbal e Not l e utilizados como vetores em reações de ligação para inserir o fragmento correspondente à seqüência codificadora de smGFP adicionada do terminador nos. Desta forma, 
foram gerados os cassetes de expressão utilizados na transformação de Arabidopsis thaliana.

\subsubsection{Transferência dos cassetes de expressão 1, 2, 3 e 4 para o vetor binário PCAMBIA 2300}

Os sítios Kpn l e Pst I foram escolhidos para a clonagem dos cassetes de expressão no vetor binário pCAMBIA 2300 (Roberts et al, 1997). A presença de um sítio de Pst I dentro dos cassetes de expressão fez com que a liberação dos cassetes fosse realizada por meio de uma digestão parcial. Os fragmentos contendo os cassetes completos foram clonados no vetor pCAMBIA 2300 de acordo com técnicas padrão de biologia molecular já descritas anteriormente.

\subsubsection{Armazenamento das bactérias transformadas com os plasmídeos utilizados nas construções gênicas}

Os plasmídeos utilizados na montagem das construções gênicas e aqueles contendo os cassetes de expressão foram usados na transformação de células competentes que foram armazenados a $-80^{\circ} \mathrm{C}$.

Células competentes da bactéria Escherichia coli estirpe JM 109 foram produzidas. Células multiplicadas em $50 \mathrm{~mL}$ de meio LB até densidade óptica de 0,5 em absorvância, medida com comprimento de onda de $600 \mathrm{~nm}\left(\mathrm{OD}_{600}\right)$, foram incubadas a $0{ }^{\circ} \mathrm{C}$ por 10 minutos e centrifugadas, $5.000 \mathrm{~g}$ a $4{ }^{\circ} \mathrm{C}$ por 3 minutos. O sobrenadante foi descartado e o precipitado, contendo as células, foi ressuspendido em $\mathrm{CaCl}_{2} 100 \mathrm{mmol} / \mathrm{L}$. Após incubação a $0{ }^{\circ} \mathrm{C}$ por 30 minutos, as células foram coletadas por centrifugação, $5.000 \mathrm{~g}$ a $4{ }^{\circ} \mathrm{C}$ por 3 minutos, concentradas pela ressuspensão em $2 \mathrm{~mL}$ de $\mathrm{CaCl}_{2} 100 \mathrm{mmol} / \mathrm{L}$ e utilizadas imediatamente. 
Essas células competentes foram transformadas pelo método de choque térmico com $150 \mathrm{ng}$ de DNA. Durante este processo, $150 \mu \mathrm{L}$ de suspensão de células competentes foi adicionada a $1 \mu \mathrm{L}$ de DNA e mantida a $0{ }^{\circ} \mathrm{C}$ por 30 minutos. Após um choque térmico de 2 minutos a $42{ }^{\circ} \mathrm{C}$, foi adicionado $1 \mathrm{~mL}$ de meio LB, seguido por incubação a $37{ }^{\circ} \mathrm{C}$ por uma hora. Em seguida, as células foram concentradas por centrifugação, ressuspendidas em $100 \mu \mathrm{L}$ de meio LB e distribuídas em placas contendo meio LB (sólido) e ampicilina $100 \mu \mathrm{g} / \mathrm{mL}$, para seleção das colônias transformantes. Uma destas colônias foi inoculada em meio LB líquido com ampicilina e crescida sob agitação por 12h. Após o crescimento, as culturas crescidas foram armazenadas a $-80^{\circ} \mathrm{C}$ em glicerol $40 \%$ (v/v). O DNA plasmidial foi purificado utilizando-se kit de purificação em colunas QIAGEN ${ }^{\circledR}$ Plasmid Mini Kit segundo recomendações do fabricante.

\subsubsection{Material vegetal}

\subsubsection{Cultivo in vivo}

O cultivo de Arabidopsis thaliana, uma planta de clima temperado, nas condições climáticas brasileiras mostrou-se bastante difícil devido ao requerimento de baixas temperaturas e iluminação especial. Para tal foi montada uma sala de crescimento com fotoperíodo de $12 \mathrm{~h}$ e temperatura variando de $22^{\circ} \mathrm{C}$ a $25^{\circ} \mathrm{C}$. O sistema de iluminação incluiu uma combinação de lâmpadas fluorescentes (três) e grolux (uma). As sementes de Arabidopsis. thaliana ecotipo Columbia foram semeadas em uma mistura de substrato vegetal (Plantmax hortaliças) e vermiculita na proporção 2:1, autocalavada por 1h. Os vasos contendo as sementes foram mantidos em bandejas plásticas cobertas por um filme plástico transparente por 60 dias para evitar perdas excessivas de umidade. Uma vez por semana as plantas foram borrifadas com solução nutritiva contendo $\mathrm{Ca}\left(\mathrm{NO}_{3}\right)_{2} 5 \mathrm{mM}, \mathrm{KNO}_{3} 5 \mathrm{mM}, \mathrm{MgSO}_{4} 2 \mathrm{mM}, \mathrm{KH}_{2} \mathrm{PO}_{4}$ 
1mM, FeEDTA (FeEDTA: $\mathrm{Na}_{2}$ EDTA $20 \mathrm{mM}$ e $\mathrm{FeSO}_{4} .7 \mathrm{H}_{2} \mathrm{O} 20 \mathrm{mM} 1 \mathrm{mM}$ ) e micronutrientes $\left(\mathrm{H}_{3} \mathrm{BO}_{3} 46 \mu \mathrm{M}, \mathrm{MnCl}_{2} .4 \mathrm{H}_{2} \mathrm{O} 9,4 \mu \mathrm{M}, \mathrm{ZnCl}_{2} 8,06 \mu \mathrm{M}, \mathrm{CuCl}_{2}\right.$ $0,37 \mu \mathrm{M}$ e $\left.\mathrm{NaMoO}_{4} \cdot 2 \mathrm{H}_{2} \mathrm{O} 0,1 \mu \mathrm{M}\right) 0,6 \mathrm{~mL} / \mathrm{L}(\mathrm{v} / \mathrm{v})$.

\subsubsection{Cultivo in vitro}

Sementes de Arabidopsis thaliana foram lavadas seis vezes com solução de benomil $0,1 \%$. Depois foram desinfestadas com ácool etílico $70 \%(\mathrm{v} / \mathrm{v})$ durante 2 minutos e hipoclorito de sódio $2 \%(\mathrm{v} / \mathrm{v})$ durante 30 minutos. Após a desinfestação, as sementes foram lavadas quatro vezes com $\mathrm{H}_{2} \mathrm{O}$ destilada estéril e ressuspendidas em fitoágar $0,1 \%(\mathrm{p} / \mathrm{v})$ para facilitar o plaqueamento. Após esse processo, as sementes foram plaqueadas em meio MS 1/2 x (Murashige \& Skoog, 1962).

\subsubsection{Transformação de Arabidopsis thaliana}

Plantas de Arabidopsis thaliana foram transformadas pelo método indireto via Agrobacterium tumefaciens de acordo com Clough \& Bent (1998), com modificações.

\subsubsection{Transformação de Agrobacterium tumefaciens GV3101::pMP90}

Agrobacterium tumefaciens da cepa GV3101::pMP90 (Koncz \& Shell, 1996) foi transformada por choque térmico, utilizando o vetor binário pCAMBIA 2300 contendo os cassetes de expressão 1, 2, 3, e 4. Para tal, células competentes de bactérias de Agrobacterium tumefaciens da cepa GV3101::pMP90 foram produzidas. Células crescidas em $50 \mathrm{~mL}$ de meio LB 
até $\mathrm{OD}_{600}$ de 0,5 foram incubadas a $0{ }^{\circ} \mathrm{C}$ por 10 minutos e centrifugadas, 3.000 g a $4{ }^{\circ} \mathrm{C}$ por 5 minutos. O sobrenadante foi descartado e o precipitado, contendo as células, foi ressuspendido em $\mathrm{CaCl}_{2} 20 \mathrm{mmol} / \mathrm{L}$ gelado e utilizado imediatamente. Essas células competentes foram transformadas pelo método de choque térmico. Neste processo, $150 \mu \mathrm{L}$ de suspensão de células competentes foram adicionados a $300 \mathrm{ng}$ de DNA e congelado em $\mathrm{N}_{2}$ líquido. Após um choque térmico de 5 minutos a $37^{\circ} \mathrm{C}$, foi adicionado $1 \mathrm{~mL}$ de meio LB, seguido por incubação a $37{ }^{\circ} \mathrm{C}$ por 3 horas. Em seguida, as células foram concentradas por centrifugação, ressuspendidas em $100 \mu \mathrm{L}$ de meio LB e distribuídas em placas contendo meio LB (sólido) e canamicina $100 \mu \mathrm{g} / \mathrm{mL}$, para seleção das colônias transformantes. Uma destas colônias foi inoculada em meio LB líquido com canamicina e crescida sob agitação por 12h. Após o crescimento as culturas foram armazenadas a $-80^{\circ} \mathrm{C}$ em glicerol $40 \%(\mathrm{v} / \mathrm{v})$.

O diagnóstico de colônias transformadas foi feito via PCR utilizando iniciadores específicos para detecção da GFP.

\subsubsection{Inoculação de Arabidopsis thaliana}

Células de Agrobacterium tumefaciens cepa GV3101 contendo os cassetes de expressão foram crescidas durante dois dias a $28^{\circ} \mathrm{C}$. A cultura crescida foi centrifugada a $4.000 \mathrm{~g}$ por 10 minutos. O sobrenadante foi descartado e o precipitado foi ressuspendido em uma solução de sacarose $5 \%$ até a $\mathrm{OD}_{600}$ de 0,8 . A essa suspensão foram adicionados $50 \mu \mathrm{L}$ do agente surfactante Silwet L-77 para cada $100 \mathrm{~mL}$ de suspensão. Para cada cassete foram preparadas aproximadamente 40 plantas, distribuídas em 8 vasos, prestes a emitir a haste floral. Para cada conjunto de 40 plantas, foram usados $150 \mathrm{~mL}$ de suspensão de Agrobacterium tumefaciens em sacarose 5\%. As plantas inoculadas foram mantidas no escuro em alta umidade por 16h. Depois, eram submetidas ao fotoperíodo original (item 3.1.2.1) até a fase de produção 
de sementes. Estas foram coletadas manualmente e recolhidas em tubos de 1,7 $\mathrm{mL}$. A coleta foi separada por vaso.

\subsubsection{Seleção e diagnóstico das plantas transformadas}

As sementes coletadas foram desinfestadas e plaqueadas em meio MS sólido contendo canamicina $(50 \mu \mathrm{L} / \mathrm{mL})$ como agente seletivo. Após 10 dias, as plantas resistentes foram transferidas para substrato vegetal nas condições descritas anteriormente ou meio MS 1/2X sem antibiótico por mais 20 dias antes de serem transferidas para o substrato.

Depois de um período de crescimento vegetativo, aproximadamente 20 $\mathrm{mg}$ de tecido foliar das plantas resistentes foram retiradas, seu DNA foi extraído segundo Edwards (1991) e usado como molde em PCRs para diagnóstico do transgene. Os iniciadores utilizados amplificaram o fragmento correspondente ao gene codificador da GFP e as reações ocorreram conforme descrito anteriormente.

\subsubsection{Análise de Arabidopsis thaliana transgênica em microscópio confocal}

\subsubsection{Condições da análise no confocal}

Plantas semeadas em terra em diferentes fases de desenvolvimento foram analisadas em microscópio confocal Zeiss modeloLSM (Laser ScanMicroscopy) 410. . A fluorescência verde foi visualizada por meio de exposição do material vegetal a um feixe de "laser" de $488 \mathrm{~nm}$ e filtro "band pass" 505-555, enquanto que a fluorescência vermelha, intrínseca dos 
cloroplastos e do corante específico para mitocôndria "MitoTracker", foi visualizada através de "laser" de 543 nm e filtro "long pass" de 570 nm.

As observações foram feitas em cada tecido separadamente. Foram usadas folhas (estômato e parênquima), haste floral (estômato e parênquima) e raiz.

\subsubsection{Tratamento com "MitoTracker"}

Os tecidos foram embebidos em solução de "MitoTracker" $4 \mu \mathrm{M}$ durante 1 hora. (Giegé et al, 2003).

\subsection{Endereçamento de THI1 de cana de açúcar}

A cana de açúcar possui várias isoformas do gene thi1. Três desses parálogos foram obtidos por meio do banco de cDNAs do SUCEST ("sugarcane expressed sequenced tags") e suas seqüências de direcionamento foram fundidas a GFP gerando 3 cassetes de expressão (Figura 7).

\subsubsection{Cassetes de expressão}

3.2.1.1 Oligonucleotídeos iniciadores e amplificação dos fragmentos contendo a seqüência de direcionamento dos parálogos de THI1 de cana de açúcar

Os oligonucleotídeos iniciadores foram desenhados com base nas seqüências obtidas do banco de dados do SUCEST. As reações de amplificação foram conduzidas como descrito anteriormente. 


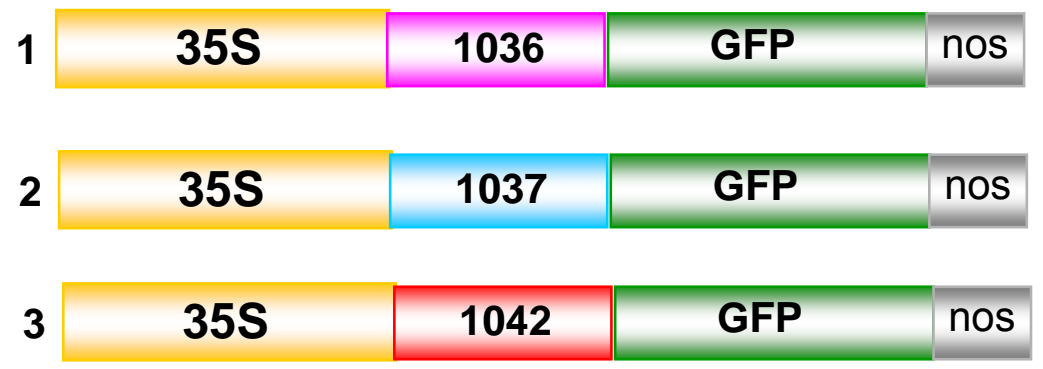

Figura 7 - Esquema dos cassetes de expressão utilizados em ensaios de expressão transiente em epiderme de cebola. 1- Promotor $35 \mathrm{~S}$ comandando a expressão da seqüência de direcionamento do clone SCQSST1036F10.g fundida a GFP+terminador nos. 2- Promotor $35 S$ comandando a expressão da seqüência de direcionamento do clone SCQSST1037E09.g fundida a GFP+terminador nos.. 3Promotor $35 \mathrm{~S}$ comandando a expressão da seqüência de direcionamento do clone SCRFST1042A04.g fundida a GFP+terminador nos

\subsubsection{Clonagem dos fragmentos em vetor pBSK$^{-}$}

Os fragmentos obtidos por meio de PCR foram digeridos com as enzimas que contêm sítios de restrição nas extremidades desses fragmentos. Estes foram utilizados em reações de ligação em que o vetor pCAMBIA 1302 (Roberts et al, 1997), foi utilizado seguindo técnicas padrão de DNA recombinante já descritas anteriormente. 


\subsubsection{Transformação via biobalística}

Nesses ensaios, $5 \mathrm{ng}$ da amostra de DNA dos cassetes de expresão da figura $X$ foram precipitados em micropartículas de tungstênio na presença de $\mathrm{CaCl}_{2} 1 \mathrm{~mol} / \mathrm{L}$, espermidina $13 \mathrm{mmol} / \mathrm{L}$ e etanol $70 \%$ (v/v) que foram depositadas em seis membranas carreadoras. Em seguida, as membranas carreadoras foram colocadas no acelerador de partículas e as partículas, recobertas com o DNA de interesse, foram aceleradas a 1100 psi contra camadas de cebola viradas para a face da epiderme.

\subsubsection{Visualização de GFP}

Após 22 horas, as epidermes bombardeadas foram observadas em

microscópio de fluorescência. A visualização de GFP foi realizada no microscópio Axiophot 2 (Zeiss), com o filtro FITC (450-490 nm). 
1) 5' CCC AGA TCT CAT GGC CAC CAC CGC GCG 3'

2) 5' CCC ACT AGT GTC CTT GGA GAG CTC 3'

3) 5' CCC ACT AGT CTC CTT GAT GGG GCT 3'

4) 5' CCC AGA TCT CGC GAG ATG ACC CGC 3'

5) 5' CCC ACT AGT CTC GCG GGA GAC GAC 3'

6) 5' CCC AGA TCT GAT GAC CCG GCG GTA C 3'

Figura 8 - Oligonucleotídeos utilizados na amplificação da seqüência de direcionamento do parálogo de THI1 SCQSST1036F10.g (1 e 2), de seu peptídeo de trânsito (1 e 3), de sua pré-seqüência (3 e 4), da seqüência de direcionamento dos parálogos de THI1 SCQSST1037E09.g e SCRFST1042A04.g (1 e 2), do peptídeo de trânsito dos parálogos de THI1 SCQSST1037E09.g e SCRFST1042A04.g (1 e 5), da pré-seqüência dos parálogos de THI-1 SCQSST1037E09.g e SCRFST1042A04.g (6 e 2). Em azul, os sítios das enzimas de restrição $B g l$ II $(1,4$ e 6) e Spe I (2, 3 e 5). Os códons de iniciação das proteínas estão em vermelho 


\subsubsection{Análises filogenéticas}

As seqüências utilizadas nos estudos evolutivos da proteína THI1 foram obtidas do banco de dados GENBANK, por meio de pesquisa no BLAST ("basic local alignment search tool") (Altschul et al., 1997) (http:// www.ncbi.nlm.nih.gov/BLAST) usando a proteína de Arabidopsis thaliana como ponto de partida. Os procedimentos de alinhamento das seqüências utilizadas e suas distâncias genéticas foram realizados no programa Clustal W (Thompson et al., 1994). As árvores filogenéticas foram visualizadas por meio do programa TreeView 1.5 (Page, 1996). 


\section{RESULTADOS E DISCUSSÃO}

\subsection{THI1 em cana de açúcar: direcionamento e filogenia}

\subsubsection{Isoformas de THI1 de cana de açúcar estão presentes apenas em cloroplastos}

Em Arabidpsis thaliana apenas uma cópia do gene thi1 gera duas isoformas da proteína que são importadas tanto por mitocôndrias quanto por cloroplastos (Chabregas et al, 2001). Porém, essa é uma situação relativamente rara pois normalmente, quando a mesma proteína é requerida em compartimentos diferentes, ocorre a duplicação gênica sendo cada produto gênico equipado com uma sequência de direcionamento distinta (revisado por Silva-Filho, 2003). A partir da observação de que em Arabidopsis thaliana existe apenas uma cópia do gene e que seu produto é direcionado simultaneamente à duas organelas distintas, tornou-se interessante avaliar se este mesmo tipo de mecanismo é observado em cana-de-açúcar. As buscas realizadas no banco de dados do SUCEST revelaram pelo menos três cópias funcionais de thi1 no genoma dessa planta. A partir desse dado acreditava-se que uma dessas cópias expressaria uma proteína direcionada para mitocôndrias e outra cópia expressaria uma proteína importada por cloroplastos. 
O mecanismo que controla o duplo direcionamento de THI1 de Arabidopsis thaliana é baseado no início alternativo da tradução, daí a presença de dois códons de início de tradução (Chabregas et al, 2003). O alinhamento entre as seqüências dos parálogos de thi1 em cana e o gene de Arabidopsis thaliana revelou uma série de diferenças entre eles (Figura 9). Porém essas diferenças estão limitadas principalmente à seqüência de direcionamento, mais especificamente ao peptídeo de trânsito (parte responsável pela importação por cloroplastos). O restante da estrutura primária, que envolve a pré-seqüência (região responsável pelo transporte para mitocôndria) e toda a parte funcional da proteína é altamente conservada, inclusive no que se refere à presença dos dois códons de iniciação da tradução.

Com o objetivo de observar o perfil de direcionamento dos parálogos (ou isoformas) de thi1 de cana foram realizadas construções gênicas com a seqüência de direcionamento completa (incluindo tanto o peptídeo de trânsito cloroplástico mais a putativa pré-sequência de direcionamento mitocondrial), somente o peptídeo de trânsito e somente a pré-seqüência dos clones SCQSST1036F10.g, SCQSST1037E09.g e SCRFST1042A04.g respectivamente, fundidas a GFP e expressas sob o comando do promotor constitutivo 35S (Figura 7). Essas construções foram expressas de forma transiente em epiderme de cebola (Figura 11-13). 

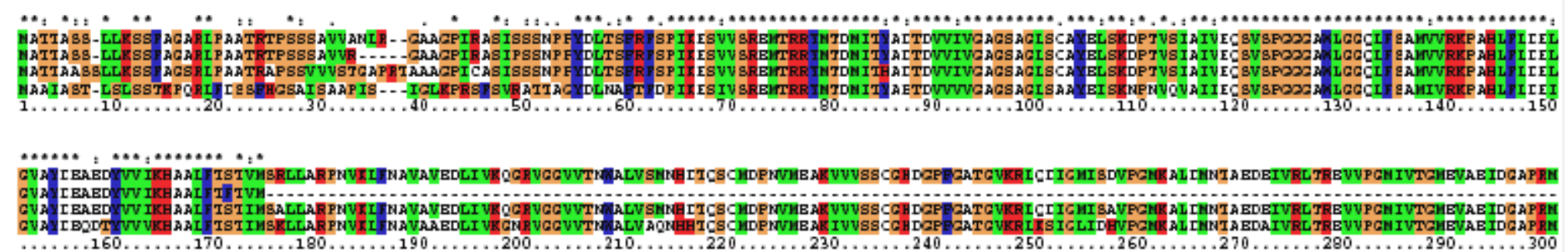

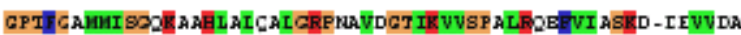

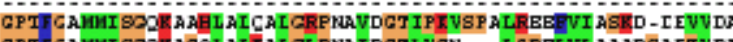

GPTI GAMGI SODAG AGOLAL

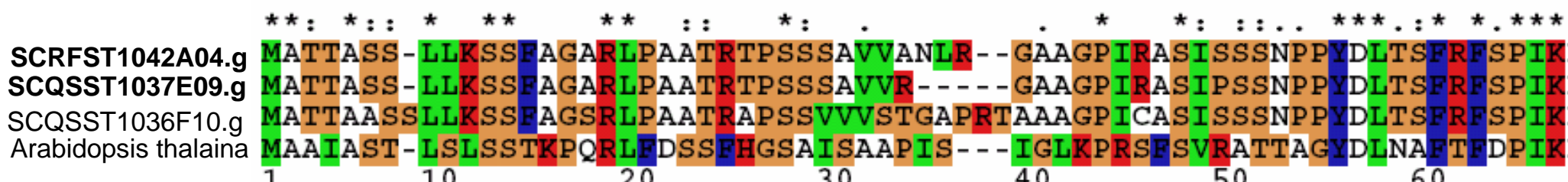

Figura 9 - Alinhamento da seqüência de aminoácidos de 3 parálogos de THI em cana de açúcar e da THI1 de Arabidopsis thaliana. 

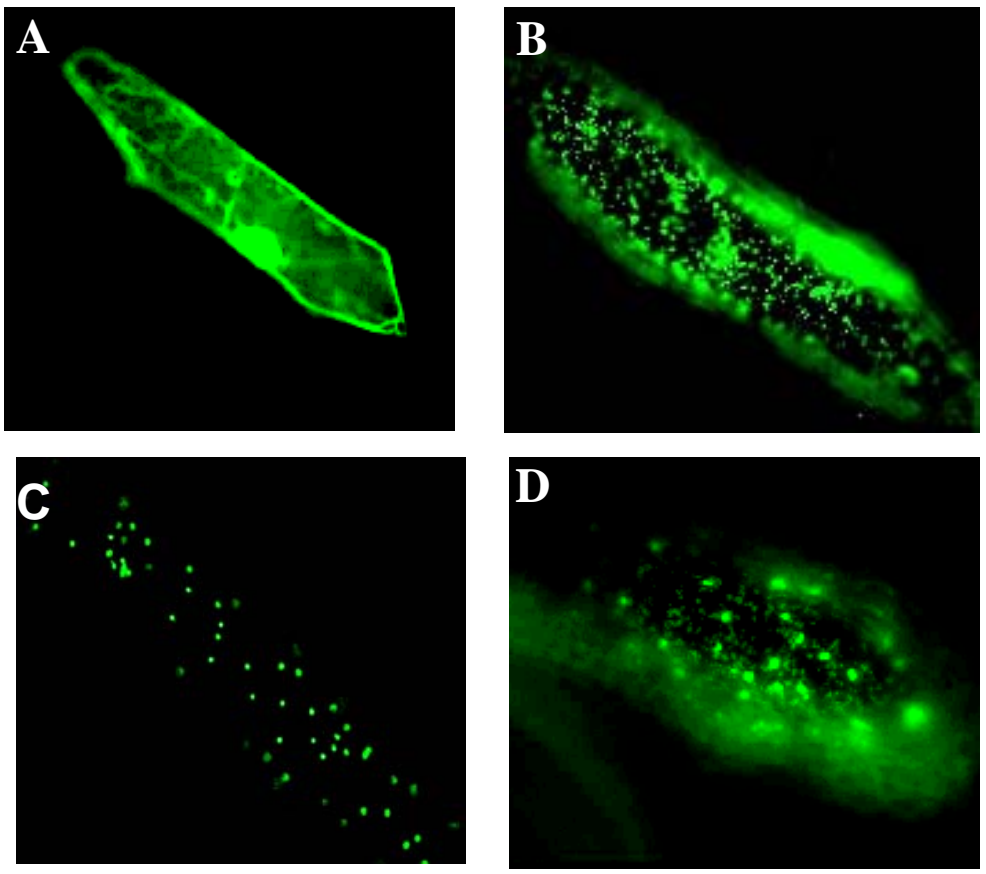

Figura 10 - Células de epiderme de cebola expressando construções gênicas utilizadas como controle de direcionamento para: A) citoplasma (pCAMBIA 1302), B) mitocôndria ( $\beta$-GFP), C) plastídeo (RecAGFP), D) cloroplasto e mitocôndria (SYCO-GFP). Aumento de aproximadamente $40 \mathrm{X}$

Para comparar os padrões de direcionamento das construções com os parálogos de thi1 em cana foram utilizados controles para citoplasma (pCAMBIA 1302) (Roberts et al., 1997), mitocôndria ( $\beta$-GFP) (cedido pelo Pr. Marc Boutry), plastídeo (RecA-GFP) (Akashi et al., 1988) e de duplo direcionamento para mitocôndrias e cloroplastos (SYCO-GFP) (Peeters et al., 2000). 

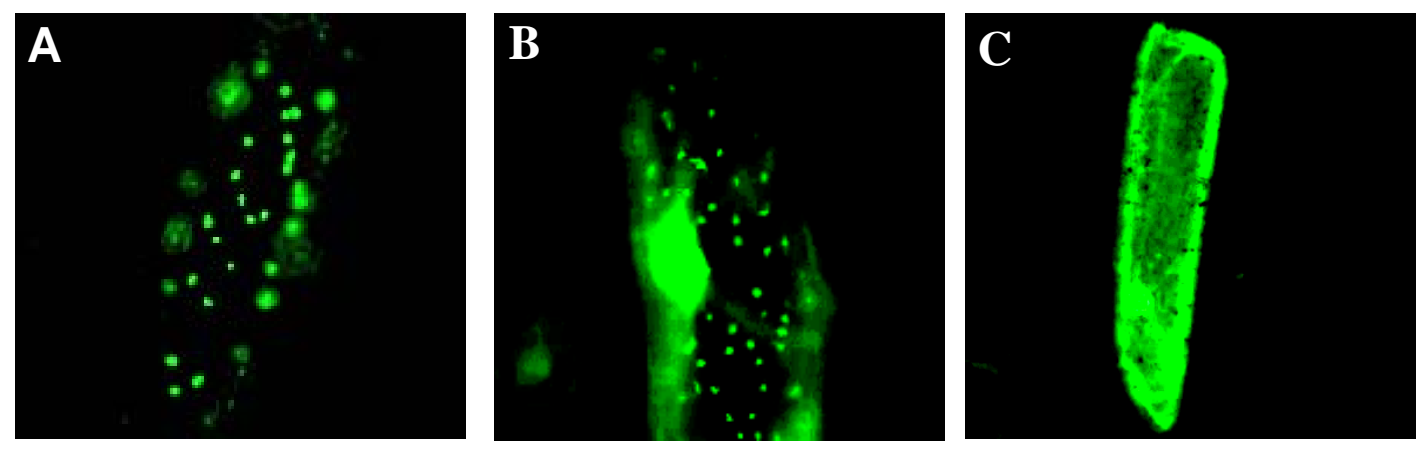

Figura 11 - Células de epiderme de cebola mostrando o transporte da proteína GFP fusionada à diferentes regiões da porção amino-terminal do parálogo SCQSST1036F10.g. A) sequência de direcionamento completa, B) peptídeo de trânsito cloroplástico, C)pré-sequência mitocondrial. Aumento de aproximadamente 40X

Como demonstrado nas figuras de 11-13, ao contrário do que acontece com a proteína THI1 de Arabidopsis thaliana, nenhuma das proteínas fusionadas apresentou o padrão de direcionamento para mitocôndrias, sugerindo que, com base nessa estratégia experimental, THI1 está presente apenas nos plastídeos de cana de açúcar, ou pelo menos, nos plastídeos de células da epiderme de cebola. $\mathrm{O}$ controle mitocondrial e plastidial indica que $\mathrm{o}$ sistema de expressão transiente utilizado é específico, uma vez que não foi constatado nenhum caso de falso direcionamento Tanto as construções contendo a seqüência de direcionamento completa quanto as que contêm somente o peptídeo de trânsito apresentaram padrão de direcionamento plastidial (Figuras 11-13 A) assim como o controle RecA (Figura $10 \mathrm{C}$ ). A explicação para a diferença no padrão de direcionamento de THI1 pode estar no tipo de sistema utilizado para os ensaios de expressão transiente. Os experimentos que acusam o duplo direcionamento de THI1 de Arabidopsis 
thaliana foram realizados em protoplastos de tabaco, ou seja, uma dicotiledônea. Já os experimentos aqui relatados foram realizados em epiderme de cebola, uma monocotiledôneas. Alguns estudos têm mostrado que sistemas de expressão heterólogos são mais específicos quando utlizados entre plantas pertencentes à mesma classe. Uma pergunta resultante destas observações é se THI1 é direcionada às mitocôndrias em cana-de-açúcar. Baseado nos resultados de Arabidopsis thaliana (Chabregas et al., 2001 e 2003), acredita-se que a falta de direcionamento mitocondrial observado reflete mais um problema com as isoformas de cana utilizadas e o sistema de expressão empregado. Pode ser que um fator citossólico, específico em cana-de-açúcar e ausente ou funcionalmente divergente em cebola, não seja capaz de permitir o direcionamento às mitocôndrias. Caso realmente a iniciação no segundo AUG use um sítio interno de entrada dos ribossomos (IRES), conforme sugerido por Chabregas e colaboradores, a presença de uma proteína específica pode ser necessária. Uma outra possibilidade é que realmente em cana-de-açúcar THI1 não é transportada às mitocôndrias, desempenhando apenas seu papel na biossíntese de tiamina. O direcionamento das isoformas de THI de cana de açúcar também está de acordo com o resultado da predição de direcionamento feita pelo programa Target $P$. 


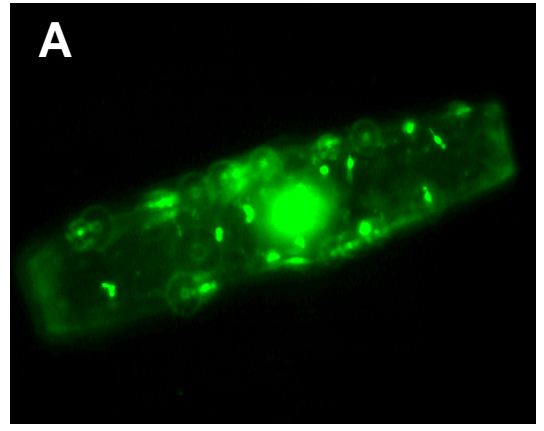

\section{$\mathbf{B}$}

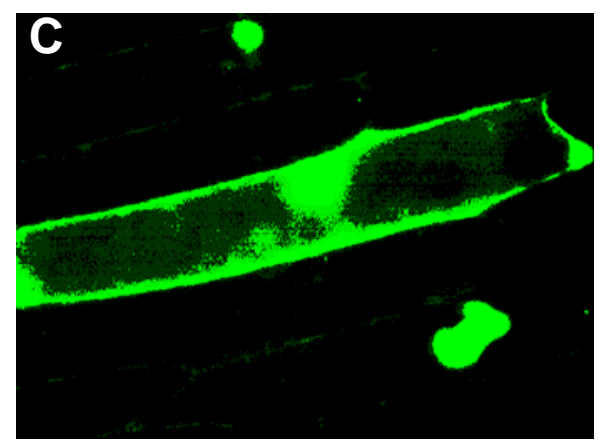

Figura 12 - Células de epiderme de cebola exibindo o transporte da proteína GFP fusionada à diferentes regiões da porção amino-terminal do parálogo SCQSST1037E09.g. A) sequência de direcionamento completa, B) peptídeo de trânsito cloroplástico, C)pré-sequência mitocondrial. Aumento de aproximadamente 40X. 

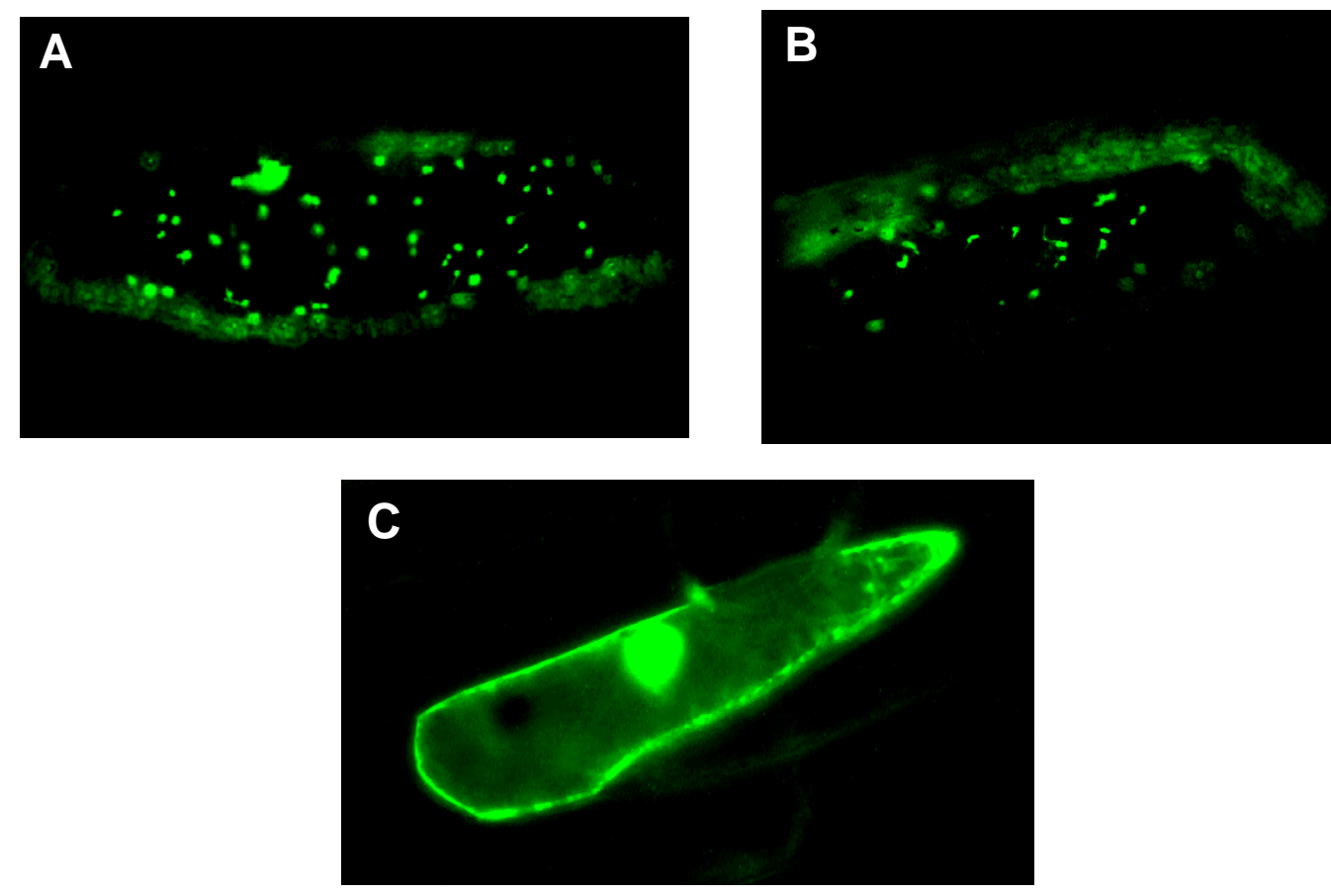

Figura 13 - Células de epiderme de cebola exibindo o transporte da proteína GFP fusionada a diferentes regiões da porção amino-terminal do parálogo SCRFST1042A04.g. A) sequência de direcionamento completa, B) peptídeo de trânsito cloroplástico, C)pré-sequência mitocondrial. Aumento de aproximadamente 40X.

\subsubsection{THI1 é provavelmente herança de Archaea}

Uma das teorias evolutivas mais aceitas na atualidade é a de que os eucariontes se estabeleceram por meio de uma relação simbiótica entre bactérias e Archaea. A análise filogenética de THI1 revelou que essa proteína em plantas está intimamente relacionada às proteínas de Archae (Figura 14) indicando que a THI1 de plantas pode ter sido herdada de Archae. Além disso, 
poucas são as bactérias que possuem um homólogo de thi1. Esse fato é surpreendente uma vez que a teoria evolutiva mais aceita atualmente sugere que os eucariontes herdaram a sua maquinaria genética de Archae e a maquinaria metabólica de bactéria (López-García \& Moreira, 1999). A presença de thi1 na bactéria Termotoga marítima provavelmente deve-se a um evento de transferência lateral, de Archaea para bactéria, o que é coerente com vários relatos na literatura envolvendo transferência lateral em Termotoga marítima (Nesbo et al, 2001). Uma outra hipótese pode ser levantada depois que análogos de THI1 foram identificados por meio de complementação em microorganismos (Morett et al., 2003). Esses análogos não possuem homologia de seqüência com THI1 mas desempenham funções equivalentes. Sendo assim, é possível que no passado as bactérias possuiam além de thi1, um análogo de função semelhante que provavelmente exercia um papel redundante no metabolismo celular. A perda de thi1 não acarretou nenhuma desvantagem adaptativa significativa para essas bactérias daí a ausência desse gene na maioria das espécies contemporâneas de bactéria. 


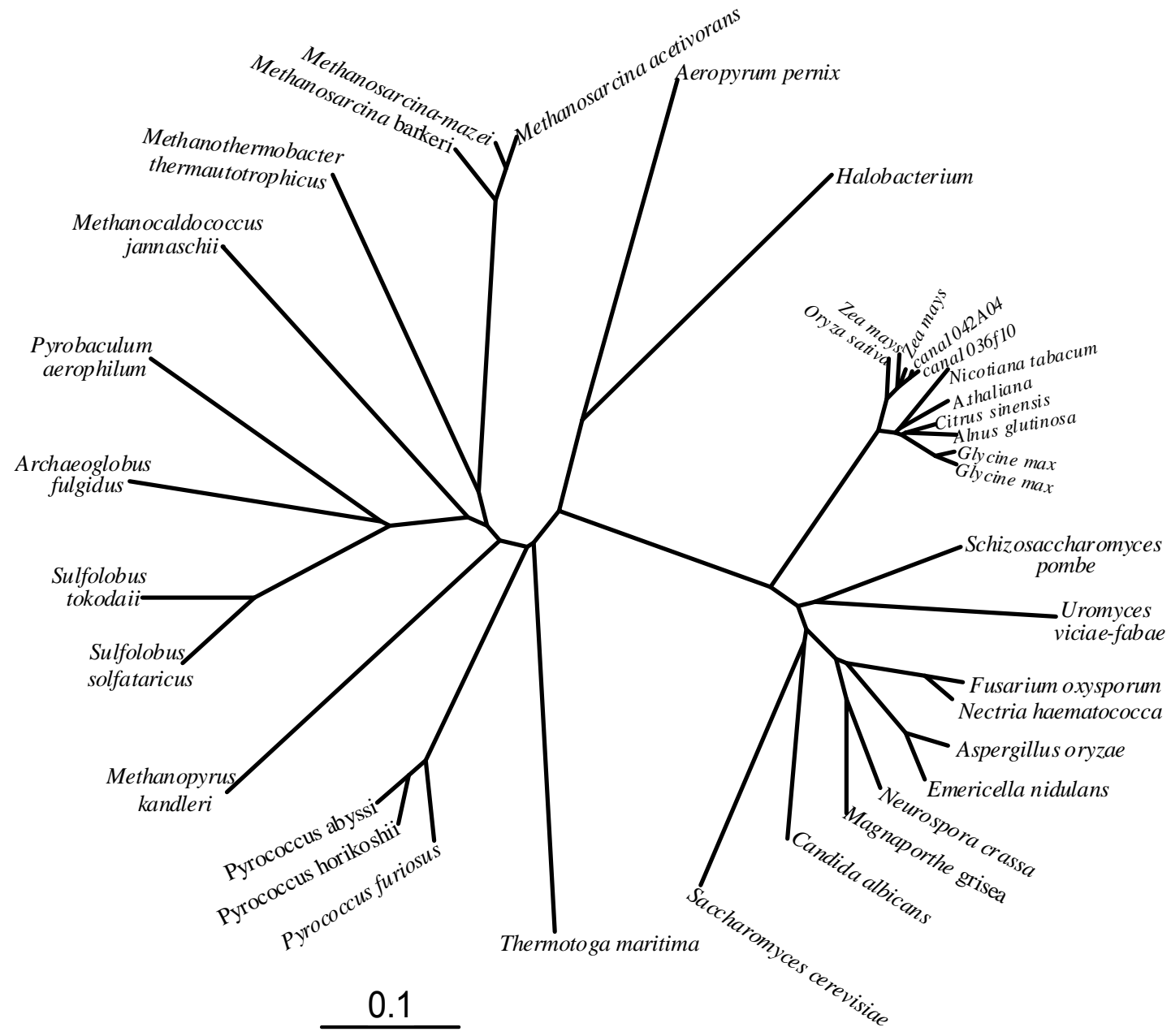

Figura 14 - Árvore filogenética não enraizada da proteína THI1. A barra significa a distância genética a partir do ancestral comum. Os números representam os valores percentuais de bootstrap, embasados em 1000 re-amostragens 


\subsection{Localização subcelular de THI1 em Arabidopsis thaliana}

\subsubsection{Análise da localização subcelular de THI1 em diferentes tecidos}

\subsubsection{THI1 está presente majoritariamente em cloroplastos de Arabidopsis thaliana expressando a construção Pr4+THI1+smGFPnos}

Dois transformantes independentes (K1/V3/P1 e K1/V1/P1) contendo a construção Pr4+THI1+smGFPnos foram avaliados quanto à localização subcelular da proteína THI1 tendo como referência a presença de GFP. Com o objetivo de observar a localização subcelular de THI1 em diferentes tecidos, plantas maduras (em fase de emissão de sementes, em torno de 70 dias) foram analisadas por meio de microscopia confocal. A identidade das estruturas fluorescentes foi inferida com base no tamanho e, no caso dos cloroplastos, por meio da autofluorescência vermelha que esta organela apresenta devido à presença de clorofila.

Como esperado, as plantas de Arabidopsis thaliana não transformadas (selvagens) não apresentaram fluorescência verde a não ser por uma região autofluorescente no centro do estômato (Figura 15). Já as plantas transgênicas K1/V3/P1 exibiram uma abundante fluorescência no interior dos cloroplastos indicando que a proteína quimérica THI1-GFP foi importada com sucesso para essa organela (Figura 16). A presença de pequenos pontos fluorescentes localizados em um plano inferior ao da imagem, aparentemente está associada aos cloroplastos, uma vez que co-localizam-se com estas organelas.

Em células do parênquima da folha (Figura 17) o padrão de fluorescência difere daquele apresentado pelos estômatos. A fluorescência aparece quase sempre associada aos cloroplastos mas em regiões concentradas na periferia da organela, semelhantemente à uma pequena estrutura associada ao envelope da organela. Esse fato pode ter ocorrido devido à grande extensão da proteína quimérica, formada pela fusão traducional entre THI1 e a GFP. Isso 
pode ter ocasionado a interrupção do processo de importação fazendo com que a proteína estacionasse na periferia e/ou formasse agregados.
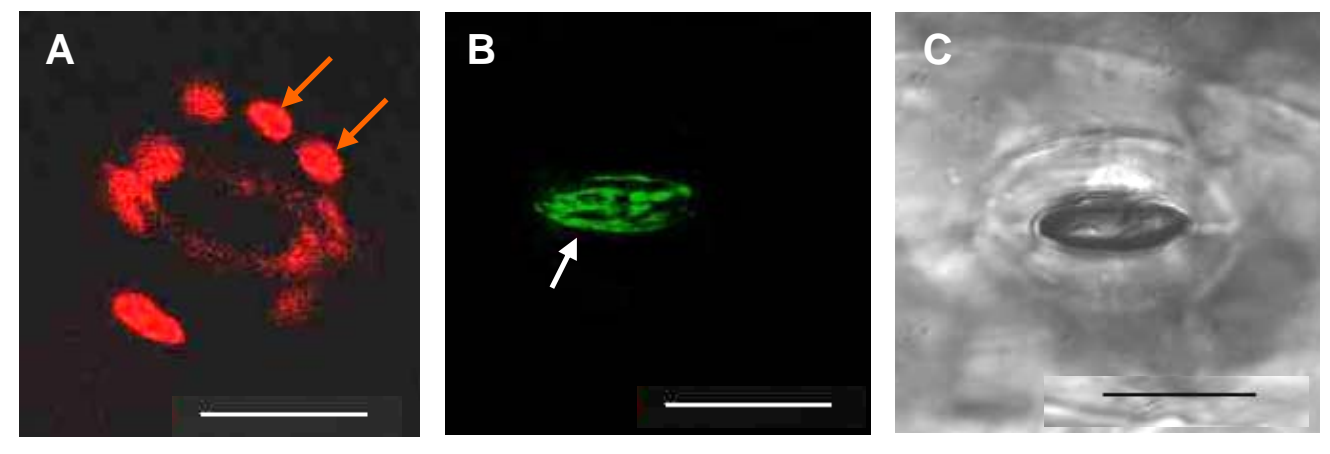

Figura 15 - Microscopia confocal. Visualização da proteína GFP em estômato foliar de Arabidopsis thaliana selvagem expressando o cassete Pr4+THI1+smGFPnos. A) autofluorescência dos cloroplastos, B)fluorescência verde, C) DIC ("digital interference contrast"). A barra representa $10 \mu \mathrm{m}$. Seta branca indica autofluorescência no centro do estômato. Setas vermelhas indicam cloroplastos. 

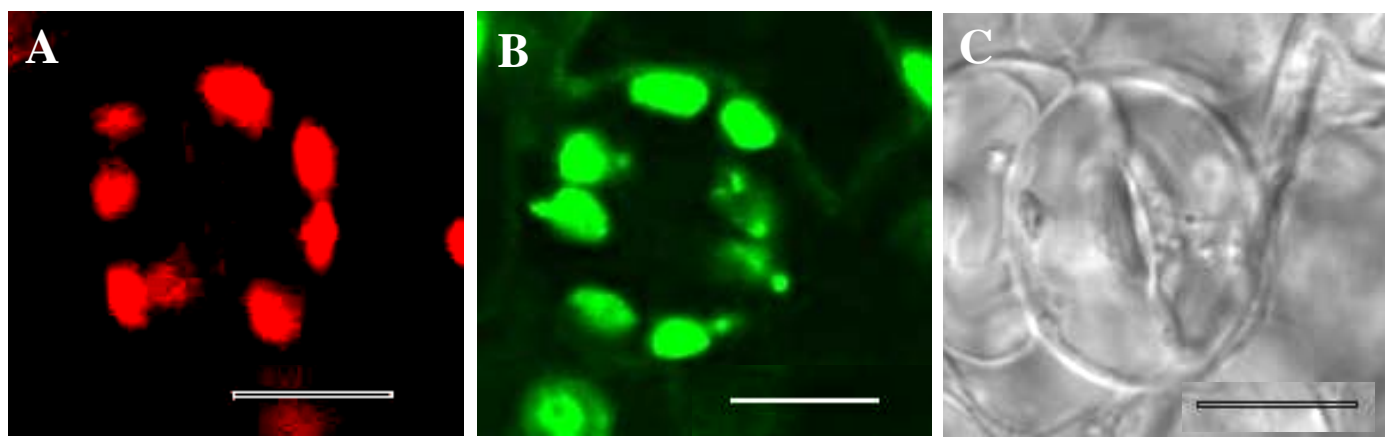

Figura 16 - Microscopia confocal. Visualização da proteína GFP em estômato foliar de Arabidopsis thaliana transgênica (K1/V3/P1) expressando o cassete Pr4+THI1+smGFPnos. A) autofluorescência dos cloroplastos, B)fluorescência de GFP, C) DIC ("digital interference contrast"). A barra representa $10 \mu \mathrm{m}$.

Uma observação semelhante foi reportada com o ortólogo de THI1 de citros, embora neste caso, a fusão foi realizada apenas com a sequência de direcionamento ou ainda com uma região adicional da proteína madura (Escobar et al., 2003). Em uma tentativa de evidenciar as mitocôndrias foi utilizado o corante MitoTracker, específico para mitocôndrias. Entretanto, a marcação com esse corante não apresentou os resultados esperados, provavelmente pelo fato de ser utilizado em tecidos íntegros que dificultam a ação do corante. Apesar disso alguma marcação foi detectada indicando que THI1 está discretamente presente em mitocôndrias (Figura 17).

Como Arabidopsis thaliana não possui caule bem definido, a haste floral foi utilizada como exemplo de um tecido que sofre alongamento. O padrão de direcionamento de THI1 fusionada a GFP foi igual ao apresentado em células do parênquima foliar (Figura 18). 
Um outro tipo de tecido avaliado foi a raiz (Figura 19). O fato de a raiz estar protegida da luz faz com que os cloroplastos não estejam presentes nesse tipo de tecido. Nas raízes de Arabidopsis thaliana predomina a presença de plastídeos e, a exemplo do que acontece com a cebola, eles não possuem pigmentação e conseqüentemente não apresentam autofluorescência. Com o objetivo de evidenciar as mitocôndrias em raiz, mais uma vez foi utilizado o corante MitoTracker. Novamente a marcação com esse corante não apresentou o padrão esperado pois as mitocôndrias são extremamente abundantes em todos os tecidos. Apesar disso alguma marcação foi detectada indicando que THI1 provavelmente não está presente em mitocôndrias de raízes pois nenhum dos pontos marcados em vermelho (MitoTracker) coincide com a marcação verde da GFP. Estes resultados, entretanto, devem ser interpretados com certa precaução uma vez que a ausência de um efetivo controle mitocondrial impede conclusões sólidas a este respeito.

A proteína THI1 está envolvida na biossíntese de tiamina e também na estabilidade do DNA mitocondrial em leveduras (Machado et al., 1997). Em plantas, a função desempenhada por THI1 em mitocôndrias ainda é desconhecida mas em cloroplastos ela está envolvida na bissíntese de tiamina. Uma hipótese interessante é que THI1 também exerça um papel na estabilidade do DNA de organelas.

A estrutura tridimensional de THI 1 foi recentemente decifrada (Godoi et al., em preparação). Uma observação interessante é que acredita-se que THI1 possa ligar-se à uma molécula de DNA. Sendo assim, a presença mesmo que discreta, de TH1 nas mitocôndrias de tecidos aéreos pode ser explicada por meio da hipótese de que esses tecidos estão mais expostos à intempéries (como a radiação ultravioleta por exemplo) e por isso THI1 estaria nas mitocôndrias atuando $\mathrm{n}$ a estabilidade do genoma. Já a biossíntese de tiamina seria uma via metabólica presente em todos os tecidos e esta seria a função desempenhada por THI1 nos cloroplastos e plastídeos. 
Um outro dado interessante a respeito da expressão da proteína quimérica THI1-GFP em raízes é que a expressão é localizada em uma região vizinha aos feixes vasculares (Figura 20). Esta observação abre hipóteses estimulantes sobre a biossíntese e transporte de tiamina em plantas embora ainda necessite de uma avaliação em um número maior de transformantes independentes.

O parênquima das síliquas também foi avaliado e apresentou o mesmo padrão de distribuição dos demais tecidos (Figura 21)

Além da planta transgênica $K 1 / \mathrm{V} 3 / \mathrm{P} 1$, um segundo transformante independente, a planta K1/V1/P1, foi analisado nas mesmas condições e exibiu exatamente o mesmo perfil de marcação com GFP da planta K1/V3/P1. 

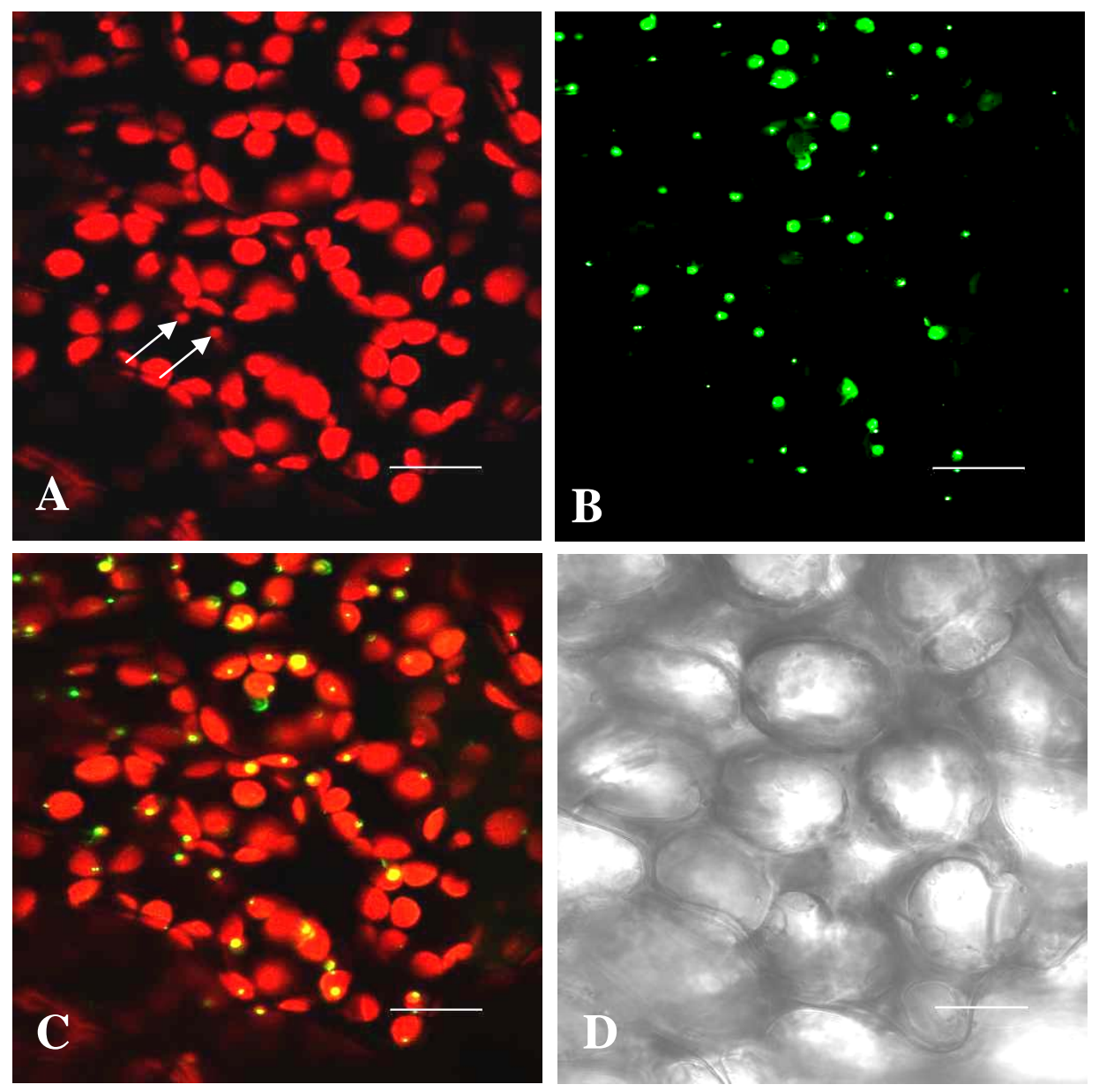

Figura 17 - Microscopia confocal. Visualização da proteína GFP em parênquima foliar de Arabidopsis thaliana transgênica (K1/N3/P1) expressando o cassete Pr4+THI1+smGFPnos. A) autofluorescência dos cloroplastos e marcação com MitoTracker (setas brancas), B) fluorescência de GFP, C) A e B fundidos e D) DIC ("digital interference contrast"). A barra representa $25 \mu \mathrm{m}$. 

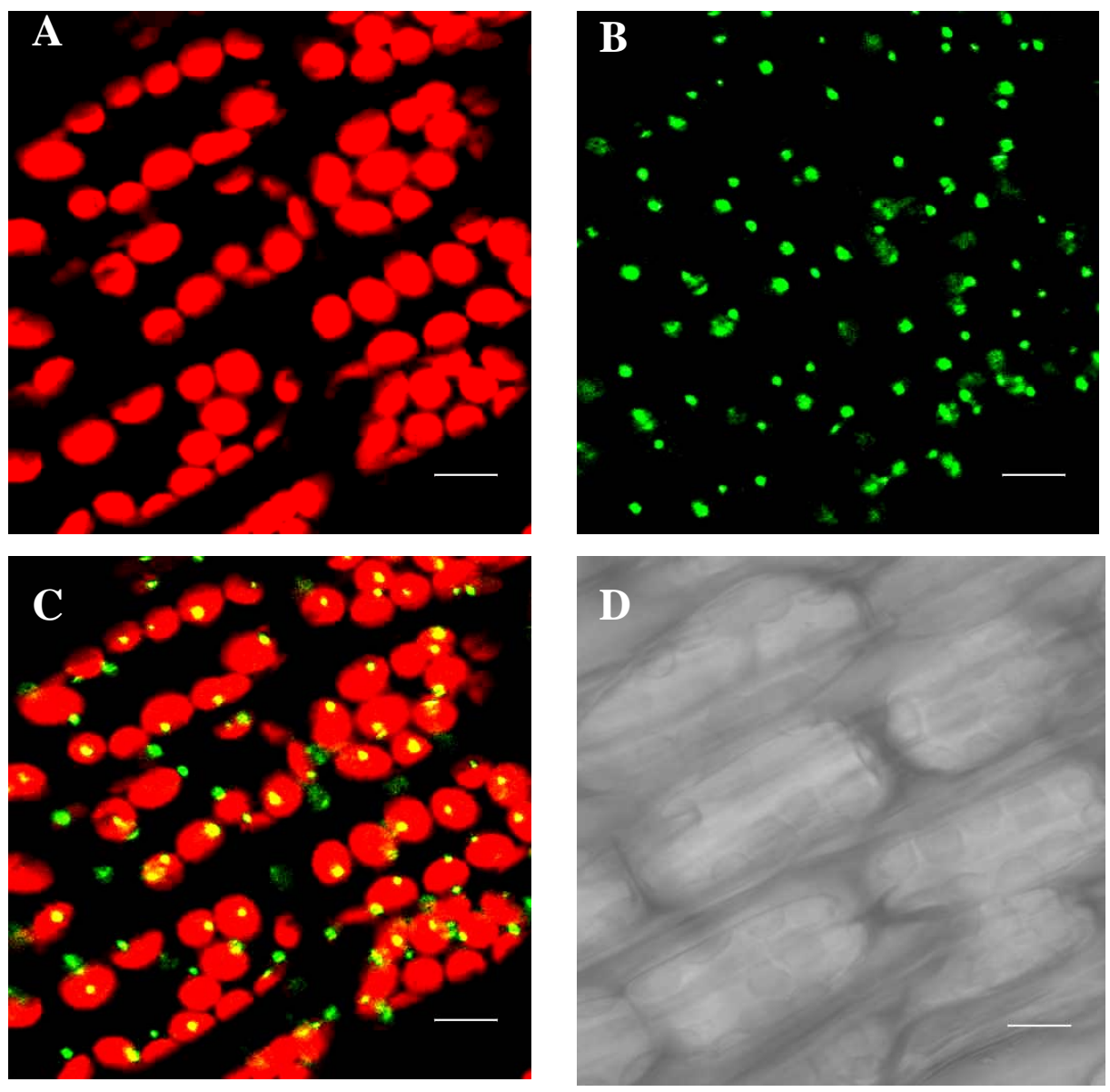

Figura 18 - Microscopia confocal. Visualização da proteína GFP na haste floral de Arabidopsis thaliana transgênica (K1/V3/P1) expressando o cassete Pr4+THI1+smGFPnos. A) autofluorescência dos cloroplastos, B) fluorescência de GFP, C) A e B fundidos e D) DIC ("digital interference contrast"). A barra representa $25 \mu \mathrm{m}$. 

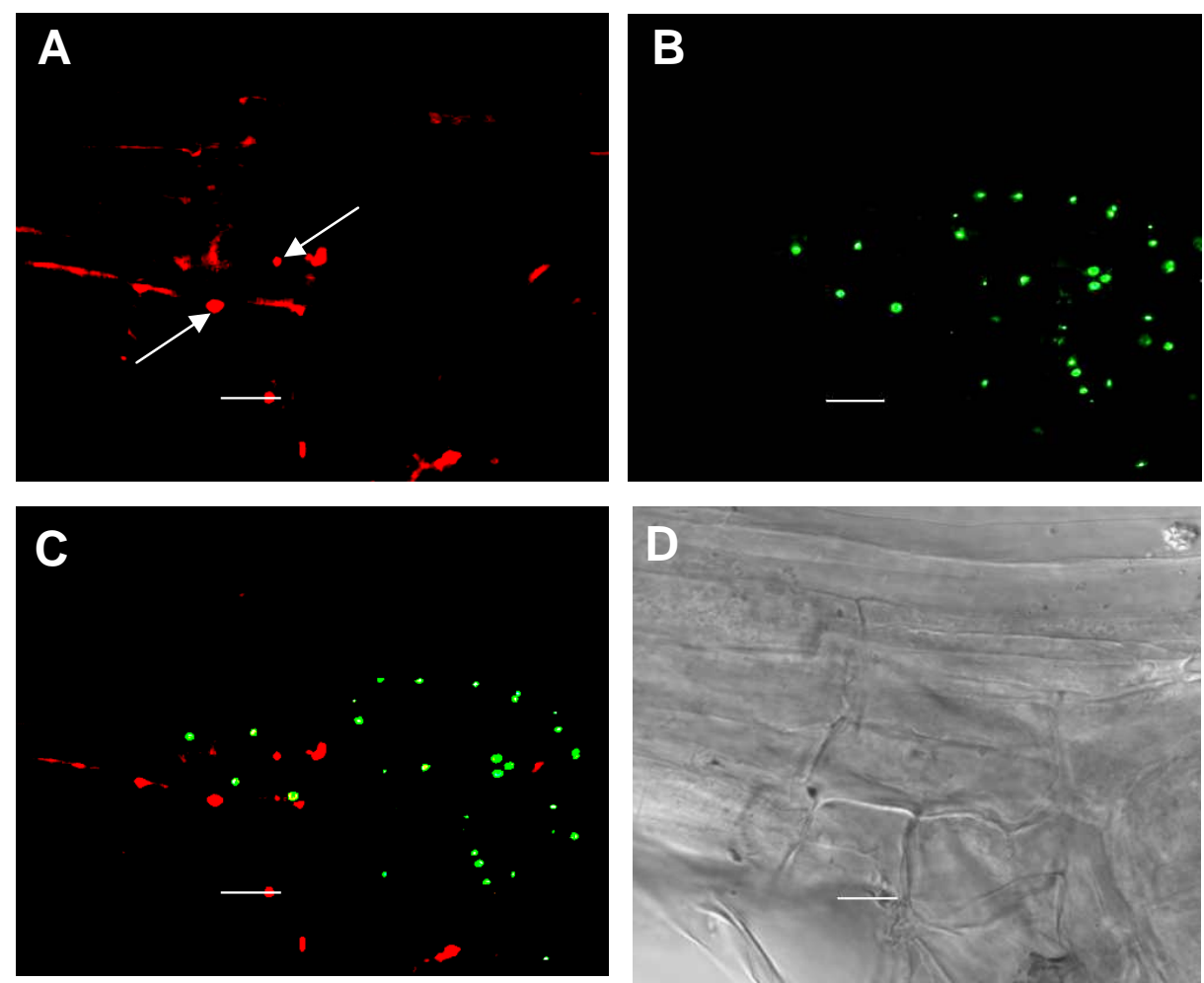

Figura 19 - Microscopia confocal. Visualização da proteína GFP na raiz de Arabidopsis thaliana transgênica (K1/V3/P1) expressando 0 cassete Pr4+THI1+smGFPnos. A) tratamento com MitoTracker (mitocôdrias indicadas por setas brancas), B) fluorescência de GFP, C) A e B fundidos e D) DIC ("digital interference contrast"). A barra representa $10 \mu \mathrm{m}$. 

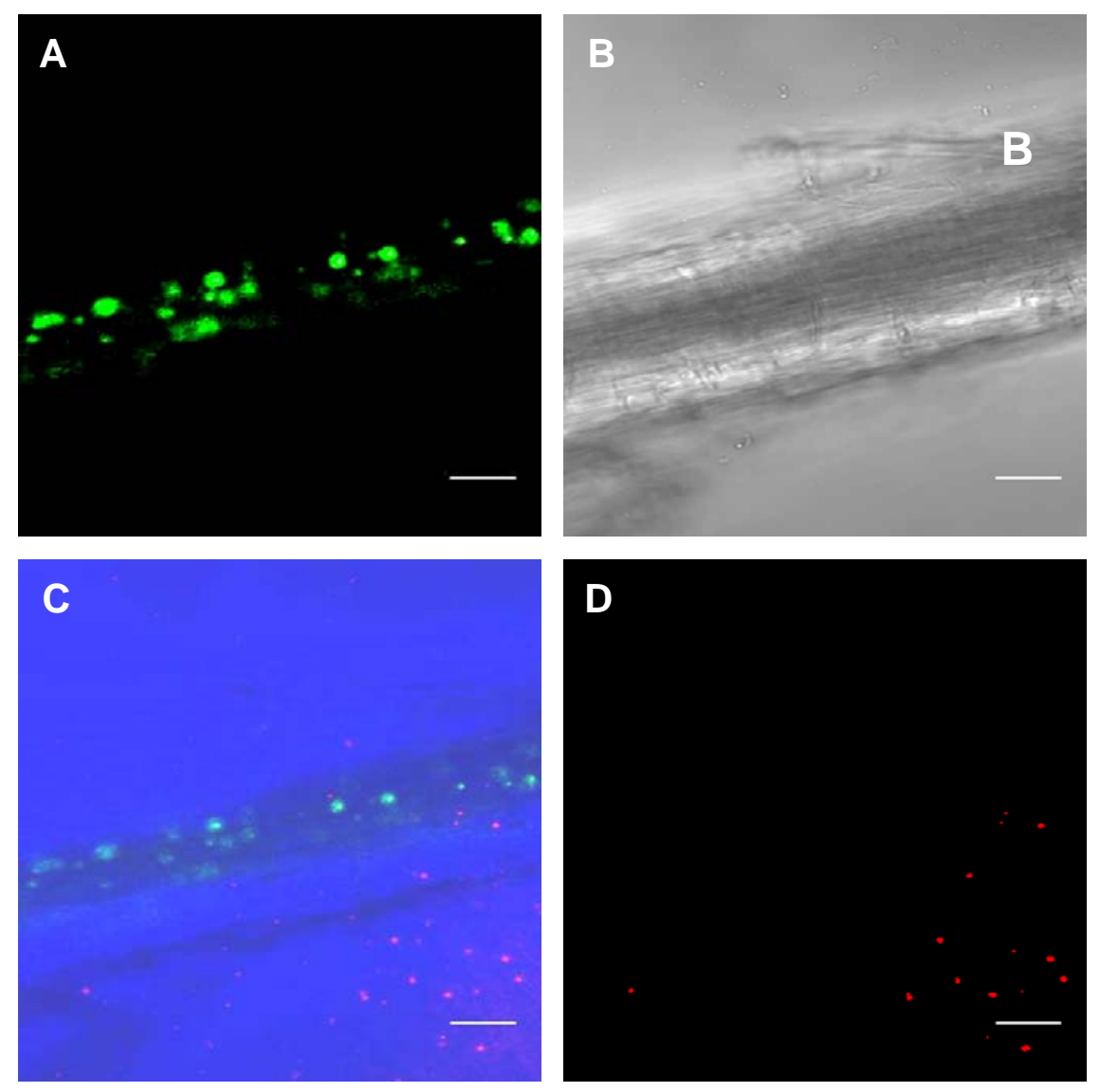

Figura 20 - Microscopia confocal. Visualização da proteína GFP na raiz de Arabidopsis thaliana transgênica (K1/V3/P1) expressando o cassete Pr4+THI1+smGFPnos. A) fluorescência de GFP B) DIC ("digital interference contrast"), C) A e B fundidos e D) imagem gerada com o filtro vermelho. A barra representa $25 \mu \mathrm{m}$. 

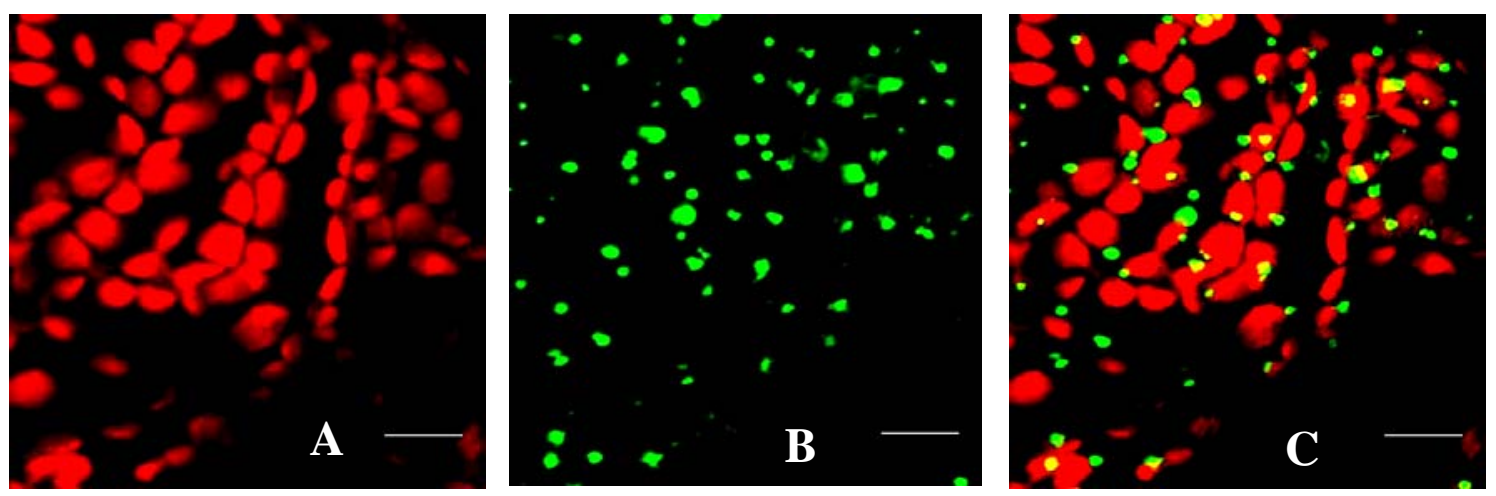

Figura 21 - Microscopia confocal. Visualização da proteína GFP em parênquima da síliqua de Arabidopsis thaliana transgênica (K1/V3/P1) expressando o cassete Pr4+THI1+smGFPnos. A) autofluorescência dos cloroplastos, B) fluorescência de GFP C) A e B fundidas. A barra representa $25 \mu \mathrm{m}$.

\subsubsection{Análise da localização subcelular de THI1 em diferentes etapas do desenvolvimento}

A fim de observar se a idade da planta influenciava a localização subcelular de THI1, foram comparados registros realizados em: plantas jovens, emitindo o segundo par de folhas verdadeiras e 15 dias; plantas adultas, com 8 pares de folhas verdadeiras e aproximadamente 40 dias e plantas maduras, em fase de florescimento, com aproximadamente 75 dias. Em todas as idades, o padrão de distribuição da proteína repórter GFP foi sempre igual ao representado pelas figuras de 16-21. Na Figura 22 tem-se uma imagem dessa distribuição em raiz, que também não apresenta nenhuma diferença entre as diferentes idades. 

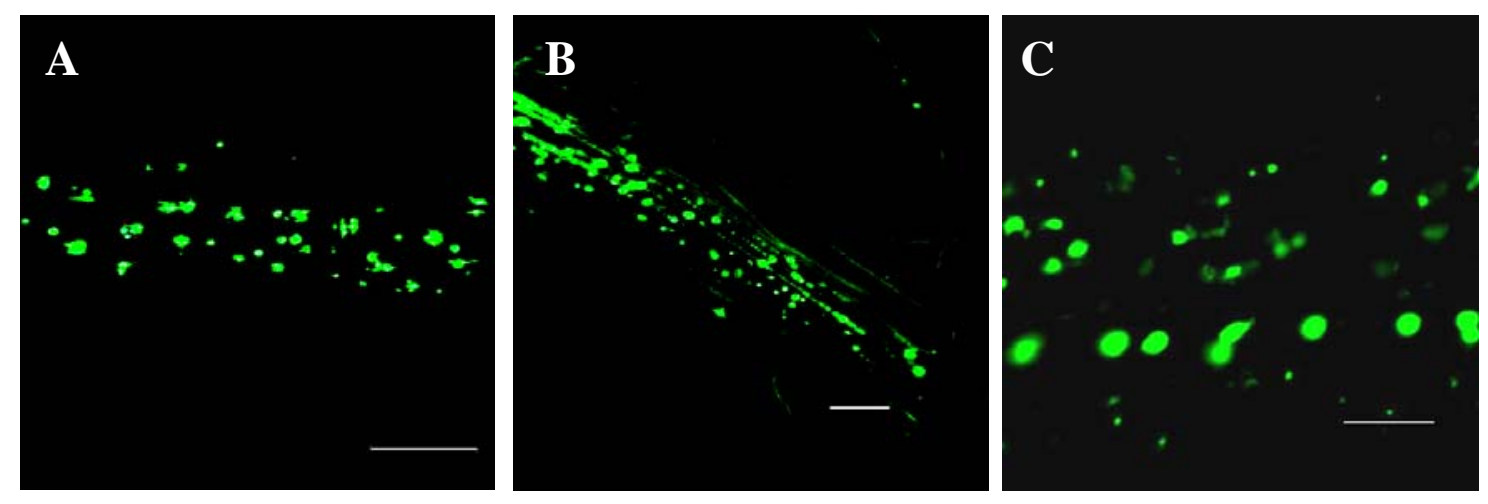

Figura 22 - Microscopia confocal. Visualização da proteína GFP em raiz de Arabidopsis thaliana transgênica (K1/V3/P1) expressando o cassete Pr4+THI1+smGFPnos. A) fluorescência de GFP em plantas com 75 dias (barra=10 $\mu \mathrm{m}$ ), B) fluorescência de GFP em plantas com 40 dias (barra $=25 \mu \mathrm{m}$ ) e C) fluorescência de GFP em plantas com 15 dias (barra $=10 \mu \mathrm{m}$ )

\subsubsection{Análise da localização subcelular de THI1 em diferentes concentrações de tiamina e tiamina pirofosfato}

Em procariotos o mecanismo de "riboswitch" em transcritos de genes envolvidos em determinadas vias metabólicas foi recentemente relatado, inclusive para a via de biossíntese de tiamina (Winkler et al, 2002; Mandal et al., 2003 e Sudarsan at al, 2003). "Riboswitch" constitui-se do controle genético por meio de elementos presentes na extremidade 5' não traduzida de certos RNAs mensageiros. Esse controle de expressão gênica apresenta duas características surpreendentes: 1) O RNAm é capaz de interagir com o metabólito-alvo de forma altamente específica; 2) A interação do metabólito- 
alvo com o RNAm promove uma mudança de conformação na molécula de RNA que compromete a tradução. Dessa forma, os produtos excessivos de determinadas vias metabólicas podem funcionar como efetores da mudança de conformação do RNA mensageiro ("riboswitch") e conseqüente impedimento da tradução. É o que acontece com o composto tiamina pirofosfato (TPP), a forma ativa da tiamina. Em .Escherichia coli, TPP se liga a transcritos envolvidos na síntese de precursores da própria TPP e impede a formação desses precursores, interrompendo a síntese de TPP (Winkler et al, 2002). O mesmo mecanismo ocorre em Bacillus subtilis para o controle da via de biossíntese de purinas (Mandal et al., 2003). Um fato interessante é que domínios de ligação a metabólitos semelhantes a "riboswitches" já foram descritos em plantas e fungos (Sudarsan at al, 2003).

Com o objetivo de analisar se os produtos finais da via de biossíntese de tiamina em plantas seriam capazes de provocar mudanças no padrão de distribuição da proteína quimérica THI1-GFP, várias concentrações de tiamina e tiamina pirofosfato foram utilizadas como suplemento do meio MS para germinação e crescimento de plantas de Arabidopsis thaliana transgênica. Para tal foram utilizadas concentrações de $0 ; 0,001 \mathrm{mM} ; 0,01 \mathrm{mM} ; 0,1 \mathrm{mM} ; 1,0 \mathrm{mM} ; 10$ $\mathrm{mM}$ e $100 \mathrm{mM}$ e as plantas foram avaliadas quanto ao padrão de expressão e localização subcelular da proteína quimérica THI1-GFP em folhas e raízes. As concentrações de $10 \mathrm{mM}$ e $100 \mathrm{mM}$ revelaram-se altamente tóxicas às plantas impedindo inclusive a germinação. Portanto foram avaliadas as plantas semeadas nas concentrações de $0 ; 0,001 \mathrm{mM} ; 0,01 \mathrm{mM} ; 0,1 \mathrm{mM} ; 1,0 \mathrm{mM}$. A concentração de $0,01 \mathrm{mM}$ de tiamina provocou a ausência de expressão da proteína quimérica THI1-GFP nas raízes (Figura 23) enquanto que na parte aérea o padrão foi o mesmo apresentado na figura 17. Nas demais concentrações o padrão não diferiu do apresentado nas figuras anteriores. 

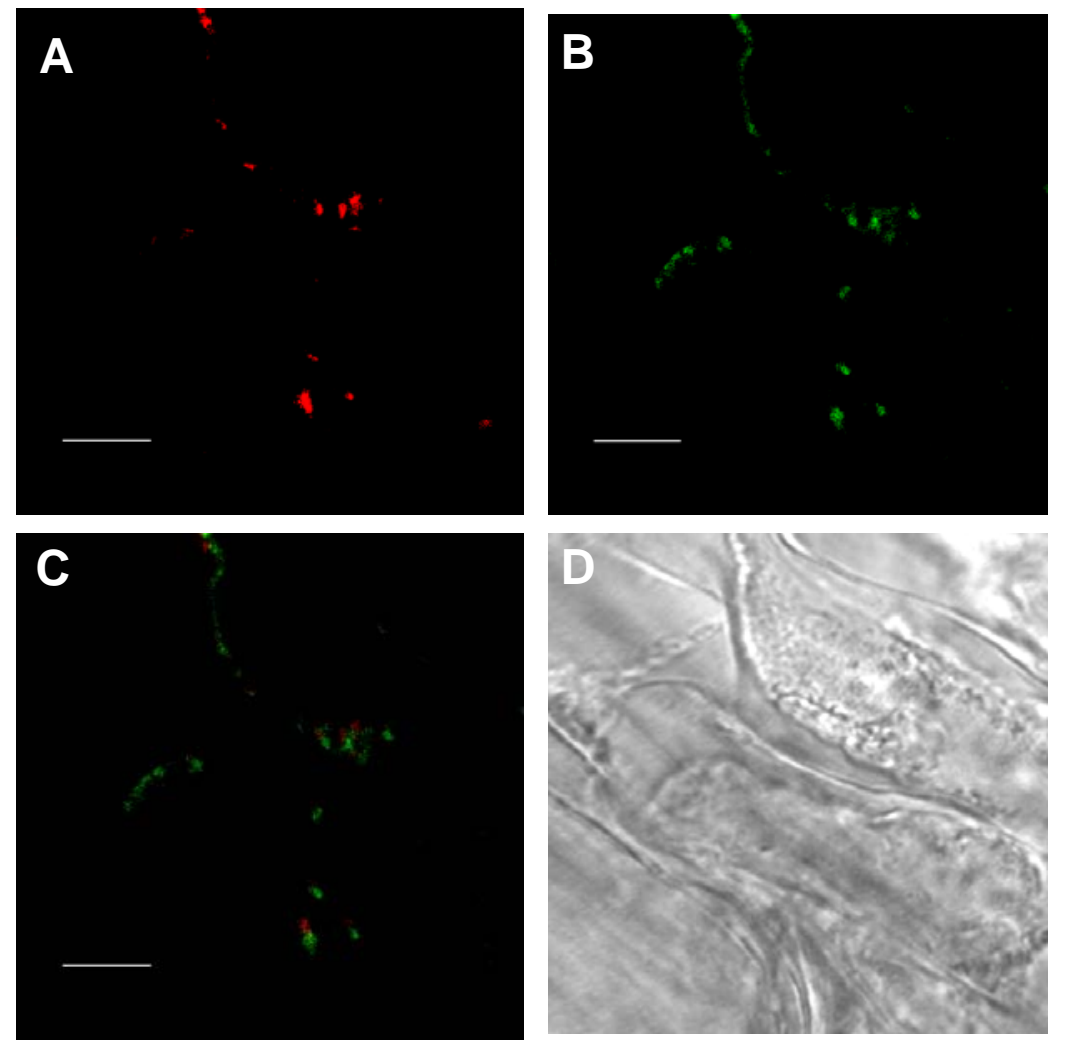

Figura 23 - Microscopia confocal. Visualização da proteína GFP na raiz de Arabidopsis thaliana transgênica (K1/V3/P1) expressando 0 cassete Pr4+THI1+smGFPnos na presença de tiamina $0,01 \mathrm{mM}$. A) imagem gerada com o filtro vermelho, B) imagem gerada com o filtro verde, C) A e B fundidos e D) DIC ("digital interference contrast"). A barra representa $10 \mu \mathrm{m}$. 
4.2.1.4 A proteína quimérica THI1-GFP não é expressa em plantas de Arabidopsis thaliana transgênica contendo a construção 35S+THI1+smGFPnos

Cinco transformantes independentes contendo a construção gênica 35S+THI1+smGFPnos (Figuras 24-26) foram avaliados quanto ao padrão de direcionamento da proteína quimérica THI1-GFP.

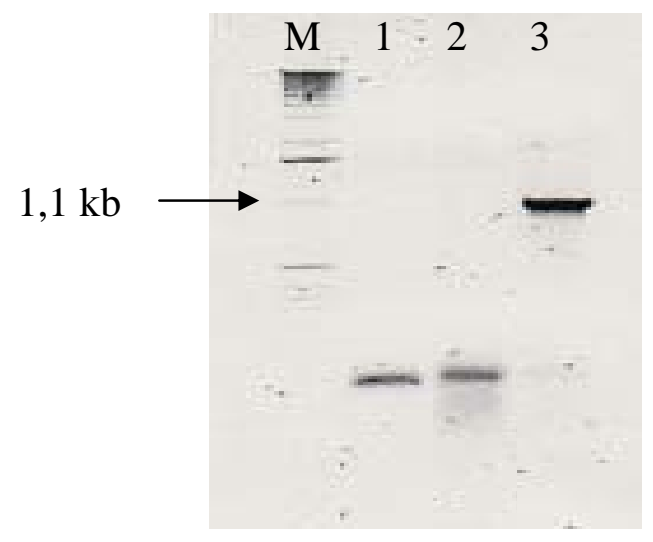

Figura 24 - Detecção do transgene GFPnos em Arabidopsis thaliana (K3/V1/P0). Linha $\mathrm{M}$, marcador de peso molecular, linha 1 reação na ausência de DNA molde, linha 2, DNA de planta selvagem usado como molde e linha 3 DNA de planta resistente usado como molde.

Nenhuma das plantas avaliadas expressava a proteína quimérica, sugerindo um mecanismo de silenciamento gênico. Esse tipo de evento tem ocorrido freqüentemente em casos de expressão acentuada de um determinado gene e esse talvez tenha sido o caso da construção sob o comando do promotor 35S. Esse promotor possui alta afinidade pelo aparato de transcrição 
e por isso acarreta uma expressão elevada dos genes sob seu comando. $\mathrm{O}$ mecanismo de silenciamento de genes mais conhecido em plantas é o pós transcripcional (PTGS) (Wang \& Waterhouse, 2001). Em fungos e animais é chamado de "quelling" e RNAinterferência respectivamente (Cogoni \& Macino, 1999; Hammond et al., 2001). Esse mecanismo se originou provavelmente como uma forma de defesa contra a infecção viral e inserções de transposons mas hoje em dia sabe-se que em vários casos de transgenia o evento de silenciamento de genes se dá por esse processo. No caso do silenciamento adicional do gene endógeno o fenômeno é chamado de co-supressão. O PTGS se baseia na degradação de RNAs mensageiros homólogos ao transgene. Toda a extensão do transgene é usada como fator de reconhecimento para o aparato de degradação do RNA mensageiro.

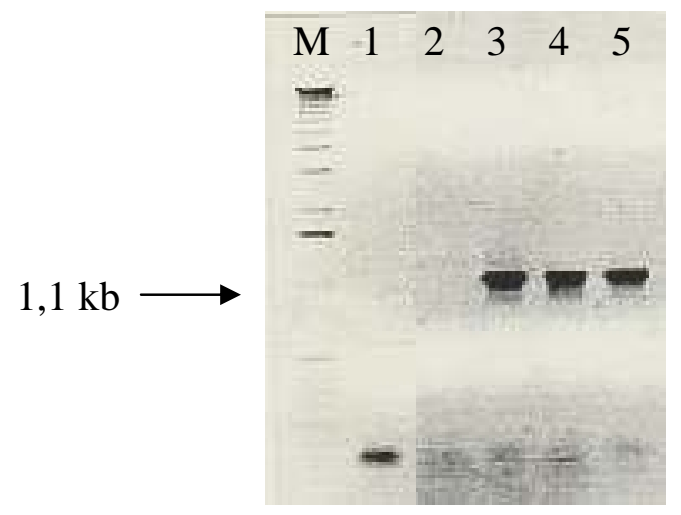

Figura 25 - Detecção do transgene GFPnos em Arabidopsis thaliana. Linha M, marcador de peso molecular. Linha 1 reação na ausência de DNA molde, linha 2 DNA de planta selvagem usado como molde, linha 3 DNA de planta resistente (K3/V2/P2) usado como molde, linha 4 DNA de planta resistente (K3/V2/P3) usado como molde e linha 5 DNA de planta resistente (K3/V2/P6) usado como molde. 
A maquinaria de reconhecimento do transgene pode ter se utilizado ora de porções pertencentes ao gene thi1, ora de porções pertencentes ao gene gfp. No primeiro caso certamente ocorreu a co-supressão, o gene endógeno também foi silenciado e as plantas transgênicas se tornaram inviáveis. No segundo caso a expressão do gene endógeno foi preservada, as plantas transgênicas são viáveis porém não expressam o transgene.

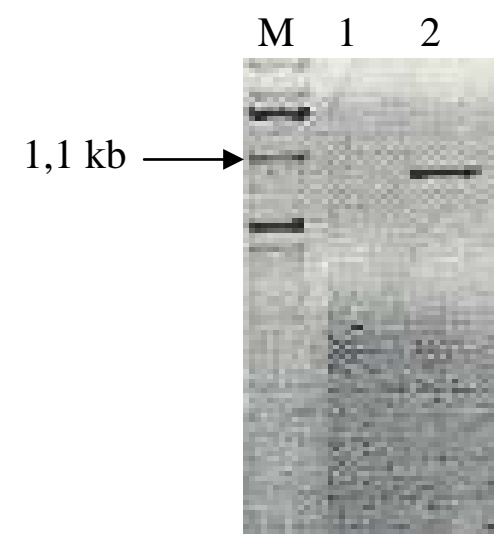

Figura 26 - Detecção do transgene GFP em Arabidopsis thaliana (K3/V1/P3). Linha $\mathrm{M}$, marcador de peso molecular, linha 1 reação na ausência de DNA molde e linha 2 DNA de planta resistente usado como molde. 


\section{CONCLUSÕES}

- THI1 está presente majoritariamente em cloroplastos de Arabidopsis thaliana expressando a construção Pr4+ THI1 +smGFPnos, independentemente do estágio de desenvolvimento e do tipo de tecido.

- THI1 de cana de açúcar está presente apenas em cloroplastos.

- THI1 de eucariotos é provavelmente herança de Archaea .

- Plantas de Arabidopsis thaliana transformadas com a construção Pr4+ THI1 +smGFPnos quando cultivadas em presença de $0,01 \mathrm{mM}$ de tiamina, não expressam a proteína quimérica nas raízes.

- A proteína de fusão THI1-GFP sob o controle do promotor transcricional constitutivo $35 \mathrm{~S}$ não é expressa em Arabidopsis thaliana. 


\section{REFERÊNCIAS BIBLIOGRÁFICAS}

ABDALLAH, F.; SALAMINI, F.; LEISTER, D. A prediction of the size and evolutionary origin of the proteome of chloroplasts of Arabidopsis. Trends in Plant Science, v.5, n.4, p.141-142, 2000.

ABE, Y.; SHODAI, T.; MUTO, T.; MIHARA K.; TORII, H.; NISHIKAWA, S.; ENDO, T.;. KOHDA D. Structural basis of presequence recognition by the mitochondrial protein import receptor Tom20. Cell, v.100, n.5, p.551-560, 2000.

AKASHI, K.; GRANDJEAN, O.; SMALL, I. Potential dual targeting of an Arabidopsis archaebacterial-like histidyl-tRNA synthase to mitochondria and chloroplasts. FEBS Letters, v.431, n.1, p.39-44, 1998.

ALCONADA, A.; KUBRICH, M.; MOCZKO, M.; HONLINGER, A.; PFANNER, N. The mitochondrial receptor complex: the small subunit Mom8b/lsp6 supports association of receptors with the general insertion pore and transfer of preproteins. Molecular and Cellular Biology, v.15, n.11, p. 6196-6205, 1995.

ALEFSEN, H.; WAEGEMAN, K.; SOLL, J. Analysis of the chloroplast protein import machinery. Journal of Plant Physiology, v.144, n.3, p.339-345, 1994. 
ALTSCHUL, S.F.; MADDEN, T.L.; SCHAFFER, A.A.; ZHANG, J.; ZHANG, Z.; MILLER, W.; LIPMAN, D.J. Gapped BLAST and PSI-BLAST: a new generation of protein database search programs. Nucleic Acids Research, v.25, n.17, 3389-3402, 1997.

AKITA, M.; NIELSEN, E.; KEEGSTRA, K. Identification of protein transport complexes in the chloroplastic envelope membranes via chemical crosslinking. The Journal of Cell Biology, v.136, n.5, p.9983-9994, 1997.

BASSHAM, D.C.; BARTLING, D.; MOULD, R.M.; DUNBAR, B.; WEISBEEK, P.; HERRMANN, R.G.; ROBINSON, C. Transport of proteins into chloroplasts. Delineation of envelope "transit" and thylakoid "transfer" signals within the pre-sequences of three imported thylakoid lumen proteins. The Journal of Biological Chemistry, v.266, n.35, p.23606-23610, 1991.

BAUER, J; CHEN, K.; HILTBRUNNER, A.; WEHRLI, E.; EUGSTER, M.; SCHNELL, D.; KESSLER, F. The major protein import receptor of plastids is essential for chloroplast biogenesis. Nature, v.403, n.6766, p.203-207, 2000.

BELANGER, F.C.; LEUSTEK, T.; CHU, B.; KRIS, A.L. Evidence for thiamine biosynthetic pathway in higher plant plastids and its developmental regulation. Plant Molecular Biology, v. 29, n.4, p. 809-821, 1995.

BERTHOLD, J.; BAUER, M.F.; SCHNEIDER, H.C.; KLAUS C.; DIETMEIER K.; NEUPERT, W.; BRUNNER, M. The MIM complex mediates preprotein translocation across the mitochondrial inner membrane and couples it to the mt-Hsp70/ATP driving system. Cell, v.81, n.7, p. 1085-1093, 1995. 
BHUSHAN; S.; LEFEBVRE, B.; STAHL, A.; WRIGHT, S.J.; BRUCE, B.D.; BOUTRY, M.; GLASER, E. Dual targeting and function of a protease in mitochondria and chloroplasts. EMBO Reports, v.4, n.11, p.1073-1078, 2003.

BOMER, U.; RASSOW, J.; ZUFALL, N.; PFANNER, N.; MEIJER, M.; MAARSE, A.C. The preprotein translocase of the inner mitochondrial membrane: evolutionary conservation of targeting and assembly of Tim17. Journal of Molecular Biology, v.262, n.4, p.389-395, 1996.

BRAUN, H.P; SCHMITZ, U.K. The protein-import apparatus of plant mitochondria. Planta, v.209, n.3, p. 267-274, 1999.

BRIX, J.; DIETMEIER, K; PFANNER, N. Differential recognition of preproteins by the purified cytosolic domains of the mitochondrial import receptors Tom20, Tom22, and Tom70. The Journal of Biological Chemistry, v.272, n.33, p. 20730-20735, 1997.

BRIX, J.; RUDIGER, S.; BUKAU, B.; SCHNEIDER-MERGENER, J.; PFANNER, N. Distribution of binding sequences for the mitochondrial import receptors Tom20, Tom22, and Tom70 in a presequence-carrying preprotein and a noncleavable preprotein. The Journal of Biological Chemistry, v.274, n.23, p.16522-16530, 1999.

BUDZISZEWSKI, G.J.; LEWIS, S.P.; GLOVER, L.W.; REINEKE, J.; JONES, G.; ZIEMNIK, L.S.; LONOWSKI, J.; NYFELER, B.; AUX, G.; ZHOU, Q; MCELVER, J.; PATTON, D.A.; MARTIENSSEN, R.; GROSSNIKLAUS, U.; MA, H.; LAW, M.; LEVIN, J.Z. Arabidopsis genes essential for seedling viability: isolation of insertional mutants and molecular cloning. Genetics, v.159, n.4, p.1765-1778, 2001. 
CALIEBE, A.; GRIMM, R.; KAISER, G.; LÜBECK, J.; SOLL, J.; HEINS, L. The chloroplastic protein import machinery contains a Rieske-type iron-sulfur cluster and a mononuclear iron-binding protein. EMBO Journal, v.16, n.24, p.7342-7350, 1997.

CHAAL, B.K.; MOULD, R.M.; BARBROOK, A.C.; GRAY, J.C.; HOWE, C.J. Characterization of a cDNA encoding the thylakoidal processing peptidase from Arabidopsis thaliana. Implications for the origin and catalytic mechanism of the enzyme. The Journal of Biological Chemistry, v.273, n.2, p.689-692, 1998.

CHABREGAS, S.M.; LUCHE, D.D.; FARIAS, L.P.; RIBEIRO, A.F.; VAN SLUYS, M-A.; MENCK, C.F.M.; SILVA-FILHO, M.C. Dual targeting properties of the $\mathrm{N}$-terminal sequence of Arabidopsis thaliana THI1 protein to mitochondria and chloroplasts. Plant Molecular Biology, v.46, n.6, p.639-650, 2001.

CHABREGAS, S.M.; LUCHE, D.D.; VAN SLUYS, M.-A.; MENCK, C.F.; SILVAFILHO, M.C. Differential usage of two in-frame translational start codons regulates subcellular localization of Arabidopsis thaliana THI1. Journal of Cell Science, v.116,n.2, p.285-291, 2003.

CHADDOCK, A.M.; MANT, A.; KARNAUCHOV, I.; BRINK, S.; HERRMANN, R.G.; KLOSGEN, R.B.; ROBINSON. C. A new type of signal peptide: central role of a twin-arginine motif in transfer signals for the delta $\mathrm{pH}$-dependent thylakoidal protein translocase. EMBO Journal, v.14, n.12, p. 2715-2722, 1995. 
CHOI, G.H.; MAREK, E.T.; SCHARDL, L.C.; RICHEY, M.G.; CHANG, S.; SMITH, D.A. sti35, a stress-responsive gene in Fusarium spp. Journal of Bacteriology, v.172, n.8, p.4522-4528, 1990.

CLINE, K.; ETTINGER, W.F.; THEG, S.M. Protein-specific energy requirements for protein transport across or into thylakoid membranes. Two lumenal proteins are transported in the absence of ATP. The Journal of Biological Chemistry, v.267, n.4, p.2688-2696, 1992.

CLOUGH, S.J.; BENT, A.F. Floral dip: a simplified method for Agrobacteriummediated transformation of Arabidopsis thaliana. The Plant Journal, v.16, n.6, p.735-743, 1998.

COGONI, C.; MACINO, G. Homology-dependent gene silencing in plants and fungi: a number of variations on the same theme. Current Opinion in Microbiology, v.2, n.6, p.657-662, 1999.

DABNEY-SMITH C.; MORI, H.; CLINE, K. Requirement of a Tha4-conserved transmembrane glutamate in thylakoid Tat translocase assembly revealed by biochemical complementation. The Journal of Biological Chemistry, v.278, n.44, p.43027-43033, 2003.

DAVIS, S.J.; VIERSTRA, R.D. Soluble, highly fluorescent variants of green fluorescent protein (GFP) for use in higher plants. Plant Molecular Biology, v.36, n.4, p.521-528, 1998.

DEKKER, P.J.; RYAN, M.T.; BRIX, J.; MULLER, H.; HONLINGER, A.; PFANNER, N. Preprotein translocase of the outer mitochondrial membrane: molecular dissection and assembly of the general import pore complex. Molecular and Cellular Biology, v.18, n.11, p.6515-6524, 1998. 
DELILLE, J.; PETERSON, E.C.; JOHNSON, T.; MOORE, M.; KIGHT, A.; HENRY, R. A novel precursor recognition element facilitates posttranslational binding to the signal recognition particle in chloroplasts. Proceedings of the National Academy Science of the USA, v.97, n.4, p.1926-1931, 2000.

DESSI, P.; SMITH, M.K.; DAY, D.A.; WHELAN, J. Characterization of the import pathway of the $F(A) d$ subunit of mitochondrial ATP synthase into isolated plant mitochondria. Archives of Biochemistry and Biophysics, v.335, n.2, p.358-368, 1996.

DESSI, P.; RUDHE, C.; GLASER, E. Studies on the topology of the protein import channel in relation to the plant mitochondrial processing peptidase integrated into the cytochrome bc1 complex. The Plant Journal, v.24, n.5, p.637-644, 2000.

DIETMEIER, K.; HONLINGER, A.; BOMER, U.; DEKKER, P.J.; ECKERSKORN, C.; LOTTSPEICH, F.; KUBRICH, M.; PFANNER, N. Tom5 functionally links mitochondrial preprotein receptors to the general import pore. Nature, v.388, n.6638, p.195-200, 1997.

DUBY, G.; BOUTRY, M. Mitochondrial protein import machinery and targeting information. Plant Science, v.162, n.4, p.477-490, 2002.

ECKART, K.; EICHACKER, L.; SOHRT, K.; SCHLEIFF, E.; HEINS, L.; SOLL, J. A Toc75-like protein import channel is abundant in chloroplasts. EMBO Reports, v.3, n.6, p.557-562, 2002. 
EDWARDS, K; JOHNSTONE, C; THOMPSON, C. A simple and rapid method for the preparation of plant genomic DNA for PCR analysis. Nucleic Acids Research, v.19, n.6, p.1349, 1991.

ENDO, T; KOHDA, D. Functions of outer membrane receptors in mitochondrial protein import. Biochimica and Biophysica Acta, v.1592, n.1, p.3-14, 2002.

ENDRES, M.; NEUPERT, W.; BRUNNER, M. Transport of the ADP/ATP carrier of mitochondria from the TOM complex to the TIM22.54 complex. EMBO Journal, v.18, n.12, p.3214-3221, 1999.

ESCOBAR, N.M.; HAUPT, S.; THOW, G.; BOEVINK, P.; CHAPMAN, S.; OPARKA, K. High-throughput viral expression of cDNA-green fluorescent protein fusions reveals novel subcellular addresses and identifies unique proteins that interact with plasmodesmata. The Plant Cell, v.15, n.7, p.15071523, 2003.

FARIAS, L.P. Caracterização genômica e investigação da região promotora do gene thi1 de Arabidopsis thaliana. São Paulo, 2001. 96p. Tese (Doutorado) Instituto de Ciências Biomédicas, Universidade de São Paulo.

FOURY, F.; ROGANTI, T.; LECRENIER, N.; PURNELLE, B. The complete sequence of the mitochondrial genome of Saccharomyces cerevisiae. Federation of European Biochemical Society Letters, v.440, n.3, p.325$331,1998$.

FULGOSI, H.; SOLL, J. The chloroplast protein import receptors Toc34 and Toc159 are phosphorylated by distinct protein kinases. The Journal of Biological Chemistry, v.277, n.11, p.8934-8940, 2002. 
GIEGE, P; HEAZLEWOOD, J.L.; ROESSNER-TUNALI, U.; MILLAR, A.H.; FERNIE, A.R.; LEAVER, C.J.; SWEETLOVE, L.J. Enzymes of glycolysis are functionally associated with the mitochondrion in Arabidopsis cells. The Plant Cell, v.15, n.9, p.2140-2151, 2003

HAMADA, S.; ITO, H.; HIRAGA, S.; INAGAKI, K.; NOZAKI, K.; ISONO, N.; YOSHIMOTO, Y.; TAKEDA, Y.;. MATSUI, H. Differential characteristics and subcellular localization of two starch-branching enzyme isoforms encoded by a single gene in Phaseolus vulgaris. The Journal of Biological Chemistry, v.277, n.19, p.16538-16546, 2002.

HAMMOND, S.M.; CAUDY, A.A.; HANNON, G.J. Post-transcriptional gene silencing by double-stranded RNA. Nature Reviews Genetics, v.2, n.2, p.110-119, 2001.

HILL, K.; MODEL, K.; RYAN, M.T.; DIETMEIER, K.; MARTIN, F.; WAGNER, R.; PFANNER, N. Tom40 forms the hydrophilic channel of the mitochondrial import pore for preproteins. Nature, v.395, n.6701, p.516-521, 1998.

HILTBRUNNER, A.; BAUER, J.; ALVAREZ-HUERTA, M.; KESSLER, F. Protein translocon at the Arabidopsis outer chloroplast membrane. Biochemistry and Cell Biology, v.79, n.5, p.629-635, 2001.

HIROHASHI, T.; HASE, T.; NAKAI, M. Maize non-photosynthetic ferredoxin precursor is missorted to the intermembrane space of chloroplasts in the presence of light. Plant Physiology, v.125, n.4, p.2154-2163, 2001. 
HONLINGER, A.; BOMER, U.; ALCONADA, A.; ECKERSKORN, C.; LOTTSPEICH, F.; DIETMEIER, K.; PFANNER, N. Tom7 modulates the dynamics of the mitochondrial outer membrane translocase and plays a pathway-related role in protein import. EMBO Journal, v.15, n.9, p.21252137, 1996.

HUGOSSON, M.; NURANI, G.; GLASER, E.; FRANZEN, L.G. Peculiar properties of the PsaF photosystem I protein from the green alga Chlamydomonas reinhardtii: presequence independent import of the PsaF protein into both chloroplasts and mitochondria. Plant Molecular Biology, v.28, n.3, p.525-535, 1995.

INOUE, K.; DEMEL, R.; DE KRUIJFF, B.; KEEGSTRA, K. The N-terminal portion of the preToc75 transit peptide interacts with membrane lipids and inhibits binding and import of precursor proteins into isolated chloroplasts. European Journal of Biochemistry, v.268, n.14, p.4036-4043, 2001.

ISAYA, G.; KALOUSEK F.; ROSENBERG, L.E. Amino-terminal octapeptides function as recognition signals for the mitochondrial intermediate peptidase. The Journal of Biological Chemistry, v.267, n.11, p. 7904-7910, 1992.

JACKSON-CONSTAN, D.; KEEGSTRA, K. Arabidopsis genes encoding components of the chloroplastic protein import apparatus. Plant Physiology, v.125, n.4, p.1567-1576, 2001.

JACOB-WILK, D.; GOLDSCHMIDT, E. E.; RIOV, J.; SADKA, A.; HOLLAND, D. Induction of a Citrus gene highly homologous to plant and yeast thi genes involved in thiamine bisynthesis during natural and ethylene-induced fruit maturation. Plant Molecular Biology, v.35, n.5, p.661-666, 1997. 
JANSCH, L.; KRUFT, V.; SCHMITZ, U.K.; BRAUN, H.P. Unique composition of the preprotein translocase of the outer mitochondrial membrane from plants. The Journal of Biological Chemistry, v.273, n.27, p.17251-17257, 1998.

JARVIS, P.; SOLL, J. Toc, Tic, and chloroplast protein import. Biochimica and Biophysica Acta, v.1541, n.1-2, p.64-79, 2001.

JULLIARD, J.H.; DOUCE, R. Biosynthesis of the thiazole moiety of thiamin (vitamin $B_{1}$ ) in higher plant chloroplasts. Proccedings of the National Academy of Sciences of the United States of America, v.88, n.6, p.20422045, 1991.

KESSLER, F.; BLOBEL, G. Interaction of the protein import and folding machineries of the chloroplast. Proceedings of the National Academy Science of the USA, v.93, n.15, p.7684-7689, 1996.

KESSLER, F.; SCHNELL, D.J. A GTPase gate for protein import into chloroplasts. Nature Structural Biology, v.9, n.2, p.81-83, 2002.

KIRCHER, S.; GIL, P.; KOZMA-BOGNÁR, L., FEJES, E.; SPETH, V.; HUSSELSTEIN-MULLER, T.; BAUER D.; ÁDÁM, E.; SCHÄFER, E.; NAGY F. Nucleocytoplasmic partitioning of the plant photoreceptors phytochrome A, B, $\mathrm{C}, \mathrm{D}$, and $\mathrm{E}$ is regulated differentially by light and exhibits a diurnal rhythm. The Plant Cell, v.14, n.7, p.1541-1555, 2002.

KOEHLER, C.M.; MURPHY, M.P.; BALLY, N.A.; LEUENBERGER, D.; OPPLIGER, W.; DOLFINI, L.; JUNNE, T.; SCHATZ, G.; OR, E. Tim18p, a new subunit of the TIM22 complex that mediates insertion of imported proteins into the yeast mitochondrial inner membrane. Molecular and Cellular Biology, v.20, n.4, p.1187-1193, 2000. 
KOMIYA, T.; ROSPERT, S; SCHATZ, G.; MIHARA, K. Binding of mitochondrial precursor proteins to the cytoplasmic domains of the import receptors Tom70 and Tom20 is determined by cytoplasmic chaperones. EMBO Journal, v.16, n.14, p.4267-4275, 1997.

KONCZ, C.; SCHELL, J. The promoter of the $T_{L}$-DNA gene 5 controls the tissuespecific expression of chimaeric genes carried by a novel type of Agrobacterium binary vector. Molecular and General Genetics, v.204, n.3, p.383-396, 1986.

KOURANOV, A.; CHEN, X.; FUKS, B.; SCHNELL, D.J. Tic20 and Tic22 are new components of the protein import apparatus at the chloroplast inner envelope membrane. The Journal of Cell Biology, v.143, n.4, p.991-1002, 1998.

KOURANOV, A.; WANG, H.; SCHNELL, D.J. Tic22 is targeted to the intermembrane space of chloroplasts by a novel pathway. The Journal of Biological Chemistry, v.274, n.35, p.25181-25186, 1999.

KÜCHLER, M.; DECKER, S.; SOLL, J.; HEINS, L. Protein import into chloroplasts involves redox-regulated proteins. EMBO Journal, v.21, n.22, p.6136-6145, 2002.

LAMPPA, G.K. The chlorophyll a/b-binding protein inserts into the thylakoids independent of its cognate transit peptide. The Journal of Biological Chemistry, v.263, n.29, p.14996 - 14999, 1988. 
LÓPEZ-GARCÍA, P.; MOREIRA, D. Metabolic symbiosis at the origin of eukaryotes. Trends in Biochemical Sciences, v.24, n.3, p.88-93, 1999.

LÜBECK, J.; SOLL, J.; AKITA, M.; NIELSEN, E.; KEEGSTRA, K. Topology of IEP110, a component of the chloroplastic protein import machinery present in the inner envelope membrane. EMBO Journal, v.15, n.16, p.4230-4238, 1996.

LUCIANO, P.; TOKATLIDIS, K.; CHAMBRE, I.; GERMANIQUE, J.C.; GELI, V. The mitochondrial processing peptidase behaves as a zinc-metallopeptidase. Journal of Molecular Biology, v.280, n.2, p.193-199, 1998.

MACASEV, D.; NEWBIGIN, E.; WHELAN, J.; LITHGOW, T. How do plant mitochondria avoid importing chloroplast proteins? Components of the import apparatus Tom20 and Tom22 from Arabidopsis differ from their fungal counterparts. Plant Physiology, v.123, n.3, p.811-816, 2000.

MACHADO, C. R.; COSTA DE OLIVEIRA, R.L.; BOITEX, S.; PRAEKELT, U.M.; MEACOCK, P.A.; MENCK, C.F.M. THI 1, a thiamin biosynthetic gene in Arabidopsis thaliana complements bacterial defects in DNA repair. Plant Molecular Biology, v.31, n.6, p.585-593, 1996.

MACHADO, C.R.; COSTA DE OLIVEIRA, R.L.; BARBOSA, A.C.C.; BYRNE, K.L; MEACOCK, P.A.; MENCK C.F.M. Dual role for the yeast thi4 gene in thiamine biosynthesis and DNA damage tolerance. Journal of Molecular Biology, v.273, n.1, p.114-121, 1997.

MANETTI, A.G.; ROSETTO, M.; MAUNDRELL, K.G. nmtll of fission yeast: a second thiamine-repressible gene co-ordinately regulated with nmtl. Yeast, v.10, n.8, p.1075-1082, 1994. 
MANDAL, M.; BOESE, B.; BARRICK, J.E.; WINKLER, W.C.; BREAKER R.R. Riboswitches control fundamental biochemical pathways in Bacillus subtilis and other bacteria. Cell, v.113,: n.5, p.577-586, 2003.

MARIENFELD, J.; UNSELD, M.; BRENNICKE, A. The mitochondrial genome of Arabidopsis is composed of both native and immigrant information. Trends in Plant Science, v.4, n.12, p.495-502, 1999.

MARTIN, J.; MAHLKE, K.; PFANNER, N. Role of an energized inner membrane in mitochondrial protein import. Delta psi drives the movement of presequences. The Journal of Biological Chemistry, v.266, n.27, p.18051-18057, 1991.

MAY, T.; SOLL, J. 14-3-3 proteins form a guidance complex with chloroplast precursor proteins in plants. The Plant Cell, v.12, n.1, p.53-63, 2000.

MICHL, D.; ROBINSON, C.; SHACKLETON, J.B.; HERRMANN, R.G.; KLÖSGEN, R.B. Targeting of proteins to the thylakoids by bipartite presequences: $\mathrm{CF}_{\mathrm{ol}}$ is imported by a novel, third pathway. EMBO Journal, v.13, n.6, p.1310-1317, 1994.

MORETT, E.; KORBEL, J.O.; RAJAN, E.; SAAB-RINCON, G.; OLVERA L.; OLVERA, M.; SCHMIDT, S.; SNEL, B.; BORK, P. Systematic discovery of analogous enzymes in thiamin biosynthesis. Nature Biotechnology, v.21, n.7, p.790-795, 2003.

MURASHIGE, T.; SKOOG, F. A revised medium for rapid growth and bioassays with tobacco tissue cultures. Plant Physiology, v.15, n.2, p.473-497, 1962. 
NAGAO, Y.; KITADA, S.; KOJIMA, K.; TOH, H.; KUHARA, S.; OGISHIMA, T.; ITO, A. Glycine-rich region of mitochondrial processing peptidase alphasubunit is essential for binding and cleavage of the precursor proteins. The Journal of Biological Chemistry, v.275, n.44, p.34552-34556, 2000.

NESBO, C.L.; L'HARIDON, S.; STETTER, K.O.; DOOLITTLE, W.F. Phylogenetic analyses of two "archaeal" genes in thermotoga maritimareveal multiple transfers between archaea and bacteria. Molecular Biology and Evolution, v.18, n.3. p.362-375, 2001.

OBARA, K.; SUMI, K.; FUKUDA, $\mathrm{H}$. The use of multiple transcription start sites causes the dual targeting of Arabidopsis putative monodehydroascorbate reductase to both mitochondria and chloroplasts. Plant and Cell Physiology, v.43, n.7, p.697-705, 2002.

PADIDAM, M.; REDDY, V.S.; BEACHY, R.N.; FAUQUET, C.M. Molecular characterization of a plant mitochondrial chaperone GrpE. Plant Molecular Biology, v.39, n.5, p.871-881, 1999.

PEETERS, N.M.; CHAPRON, A.; GIRITCH, A.; GRANDJEAN, O.; LANCELIN, D.; LHOMME T.; VIVREL, A.; SMALL, I. Duplication and quadruplication of Arabidopsis thaliana cystenil- and asparaginyl-tRNA synthetase genes of organellar origin. Journal of Molecular Evolution, v.50, n.5, p.413-423, 2000. 
PEETERS, N.; SMALL, I. Dual targeting to mitochondria and chloroplasts. Biochimica and Biophysica Acta, v.1541, n.1-2, p.54-63, 2001.

PFANNER, N.; GEISSLER, A. Versatility of the mitochondrial protein import machinery. Nature Reviews in Molecular Cell Biology, v.2, n.5, p.339349, 2001.

POLCICOVA, K.; KEMPNA, P.; SABOVA, L.; GAVURNIKOVA, G.; POLCIC, P.; KOLAROV, J. The delivery of ADP/ATP carrier protein to mitochondria probed by fusions with green fluorescent protein and beta-galactosidase. FEMS Yeast Research, v.4, n.3, p.315-321, 2003.

RENSINK, W.A.; SCHNELL, D.J.; WEISBECK, P.J. The transit sequence of ferredoxin contains different domains for translocation across the outer and inner membrane of the chloroplast envelope. The Journal of Biological Chemistry, v.275, n.14, p.10265-10271, 2000.

RIBEIRO, A.; PRAEKELT, U.; AKKERMANS, A.D.L.; MEACOCK, P.A.; KAMMEN, A. V.; BISSELING, T.; PAWLOWSKI, K. Identification of agthi1, whose product is involved in biosynthesis of the thiamine precursor thiazole, in actinorhizal nodules of Alnus glutinosa. The Plant Journal, v.10, n.2, p.361-368, 1996.

ROBERTS, C.S.; RAJAGOPAL, S.; SMITH, L.A.; NGUYEN, T.A.; YANG, W.; NUGROHO, S.; RAVI, K.S.; CAO, M-L.; VIJAYACHANDRA, K.; PATELLI, V.; HARCOURT, R.L.; DRANSFIELD, L.; DESAMERO, N.; SLAMET, I.; KEESE, P.; KILIAN, A.; JEFFERSON, R.A. pCAMBIA Vector Release Manual Version 3.05, http://www.cambia.org .29/01/2004. 
ROBINSON, C.; HYNDS, P.J.; ROBINSON, D.; MANT, A. Multiple pathways for the targeting of thylakoid proteins in chloroplasts. Plant Molecular Biology, v.38, n.1-2, p.209-21, 1998.

RODRÍGUEZ-CONCEPCIÓN, M.; YALOVSKY, S; ZIK, M.; FROMM, H.; GRUISSEM, W. The prenylation status of a novel calmodulin directs plasma membrana or nuclear localization of the protein. EMBO Journal, v.18, n.7, p.1996-2007, 1999.

ROHL, T.; VAN WIJK, K.J. In vitro reconstitution of insertion and processing of cytochrome $\mathrm{f}$ in a homologous chloroplast translation system. The Journal of Biological Chemistry, v.276, n.38, p.35465-35472, 2001.

RUDHE, C.; CLIFTON, R.; WHELAN, J.; GLASER E. N-terminal domain of the dual-targeted pea glutathione reductase signal peptide controls organellar targeting efficiency. Journal of Molecular Biology, v.324, n.4 , p.577-585, 2002.

RYAN, K.R.; LEUNG, R.S.; JENSEN, R.E. Characterization of the mitochondrial inner membrane translocase complex: the Tim23p hydrophobic domain interacts with Tim17p but not with other Tim23p molecules. Molecular and Cellular Biology, v.18, n.1, p.178-187, 1998.

SAKAMOTO, K.; BRIGGS, W. R. Cellular and subcellular localization of phototropin 1. The Plant Cell, v.14, n.8, p.1723-1735, 2002.

SAMBROOK, J.; RUSSEL, D.W. Molecular cloning: a laboratory manual. 3.ed. New York: Cold Spring Harbor Laboratory, 2001.3v. 
SCHLEIFF, E.; HEARD, T.S.; WEINER, H. Positively charged residues, the helical conformation and the structural flexibility of the leader sequence of pALDH are important for recognition by hTom20. Federation of European Biochemical Society Letters, v.461, n.1-2, p.9-12, 1999.

SCHLEIFF, E.; TIEN, R.; SALOMON, M.; SOLL J. Lipid composition of outer leaflet of chloroplast outer envelope determines topology of OEP7. Molecular Biology of the Cell, v.12, n.12, p.4090-4102, 2001.

SCHLEIFF, E.; MOTZKUS, M.; SOLL, J. Chloroplast protein import inhibition by a soluble factor from wheat germ lysate. Plant Molecular Biology, v.50, n.2, p.177-185, 2002.

SCHLEIFF, E.; SOLL, J.; SVESHNIKOVA, N.; TIEN, R.; WRIGHT, S.; DABNEYSMITH, C.; SUBRAMANIAN, C.; BRUCE, B.D. Structural and GTP/GDP requirements for transit peptide recognition by the cytosolic domain of the chloroplast outer envelope receptor, Toc34. Biochemistry, v.41, n.6, p.1934-1946, 2002.

SCHLOSSMANN, J.; LILL, R.; NEUPERT, W.; COURT, D.A. Tom71, a novel homologue of the mitochondrial preprotein receptor Tom70. The Journal of Biological Chemistry, v.271, n.30, p.17890-17895, 1996.

SCHNEIDER, A.; OPPLIGER, W.; JENO, P. Purified inner membrane protease I of yeast mitochondria is a heterodimer. The Journal of Biological Chemistry, v.269, n.12, p.8635-8638, 1994.

SCHNEIDER, G.; SJOLING, S.; WALLIN, E.; WREDE, P.; GLASER, E.; VON HEIJNE, G. Feature-extraction from endopeptidase cleavage sites in mitochondrial targeting peptides. Proteins, v.30, n.1, p.49-60, 1998. 
SILVA-FILHO, M.C.; WIEERS, U.I.; FLUGGE, CHAUMONT, F.; BOUTRY M. Different in vitro and in vivo targeting properties of the transit peptide of a chloroplast envelope inner membrane protein. The Journal of Biological Chemistry, v.272, n.24, p.15264-15269, 1997.

SILVA-FILHO, MC. One ticket for multiple destinations: dual targeting of proteins to distinct subcellular locations. Current Opinion in Plant Biology, v.6, n.6, p.589-595, 2003.

SOHRT, K.; SOLL, J. Toc64, a new component of the protein translocon of chloroplasts. The Journal Cell Biology, v.148, n.6, p.1213-1221, 2000.

SOLL, J. Protein import into chloroplasts Current Opinion in Plant Biology, v.5, n.6, p.529-535, 2002.

STROBEL, G.; ZOLLNER, A.; ANGERMAYR, M.; BANDLOW, W. Competition of spontaneous protein folding and mitochondrial import causes dual subcellular location of major adenylate kinase. Molecular Biology of the Cell, v.13, n.5, 1439-1448, 2002.

STRUB, A.; LIM, J.H.; PFANNER, N.; VOOS, W. The mitochondrial protein import motor. The Journal of Biological Chemistry, v.381, n.9-10, p.943$949,2000$.

SUDARSAN, N; BARRICK, J.E.; BREAKER, R.R. Metabolite-binding RNA domains are present in the genes of eukaryotes. RNA, v.9, n.6, p.644-647, 2003. 
SUN, Y.J.; FOROUHAR, F.; LI, H.; TU, S.-L.; YEH, Y.-H.; KAO, S.; SHR, H.-L.; CHOU, C.-C.; CHEN, C.; HSIAO, C.-D. Crystal structure of pea Toc34, a novel GTPase of the chloroplast protein translocon. Nature Structural Biology, v.9, n.2, p.95-100, 2002.

SZIGYARTO, C.; DESSI, P.; SMITH, M.K.; KNORPP, C.; HARMEY, M. A.; DAY, D. A.; GLASER, E.; WHELAN J. The three modules of ADP/ATP carrier cooperate in receptor recruitment and translocation into mitochondria. EMBO Journal, v.20, n.5, p.951-60, 2001.

THOMPSON, J.D.; HIGGINS, D.G.; GIBSON, T.J.; CLUSTAL, W. Improving the sensitivity of progressive multiple sequence alignment through sequence weighting, position-specific gap penalties and weight matrix choice. Nucleic Acids Research, v.22, n.22, p.4673-4680, 1994.

TISSIER, C; WOOLHEAD, C.A.; ROBINSON, C. Unique structural determinants in the signal peptides of "spontaneously" inserting thylakoid membrane proteins. European Journal of Biochemistry, v.269, n.13, p.3131-41, 2002.

UNSELD, M.; MARIENFELD, J.R.; BRANDT P.; BRENNICKE, A. The mitochondrial genome of Arabidopsis thaliana contains 57 genes in 366,924 nucleotides. Nature Genetics, v.15, n.1, p.57-61, 1997.

VAN WILPE, S.; RYAN, M.T.; HILL, K.; MAARSE, A.C.; MEISINGER, C.; BRIX, J.; DEKKER, P.J.; MOCZKO, M.; WAGNER, R.; MEIJER, M.; GUIARD, B; HÖNLINGER, A.; PFANNER, N. Tom22 is a multifunctional organizer of the mitochondrial preprotein translocase. Nature, v.401, n.6752, p.485-489, 1999. 
VERE, P.S.V.; BENNETT, T.M.; OBLONG, J.E.; LAMPPA, G.K. A Chloroplast Processing Enzyme Involved in Precursor Maturation Shares a Zinc-Binding Motif with a Recently Recognized Family of Metalloendopeptidases. Proceedings of the National Academy Science of the USA, v.92, n.16, p.7177-7181, 1995.

VON HEIJNE, G. Mitochondrial targeting sequences may form amphiphilic helices. EMBO Journal, v.5, n.6, p.1335-1342, 1986.

WAEGEMANN, K.; SOLL, J. Phosphorylation of the transit sequence of chloroplast precursor proteins. The Journal of Biological Chemistry, v.271, n.11, p.6545-6554, 1996.

WANG, M.B.; WATERHOUSE, P.M. Application of gene silencing in plants. Current Opinion in Plant Biology, n.5, v.2, p. 146-150, 2002.

WERHAHN, W.; NIEMEYER, A.; JANSCH, L.; KRUFT, V.V.; SCHMITZ, U.K.; BRAUN, H.P. Purification and characterization of the preprotein translocase of the outer mitochondrial membrane from Arabidopsis. Identification of multiple forms of TOM20. Plant Physiology, v.125, n.2, p.943-954, 2001.

WEXLER, M.; BOGSCH, E.G.; KLOSGEN, R.B.; PALMER, T.; ROBINSON, C.; BERKS B.C. Targeting signals for a bacterial Sec-independent export system direct plant thylakoid import by the delta $\mathrm{pH}$ pathway. Federation of European Biochemical Society Letters, v.431, n.3, p.339-342, 1998.

WIEDEMANN, N.; PFANNER, N.; RYAN, M.T. The three modules of ADPIATP carrier cooperate in receptor recruitment and translocation into mitochondria. EMBO Journal, v.20, n.5, p.951-960, 2001. 
WINKLER, W.; NAHVI, ALI.;. BREAKER, R.R. Thiamine derivatives bind messenger RNAs directly to regulate bacterial gene expression. Nature, v.419, n.6910, p.952-956, 2002.

YANG, M.; JENSEN, R.E.; YAFFE, M.P.; OPPLIGER, W.; SCHATZ, G. Import of proteins into yeast mitochondria: the purified matrix processing protease contains two subunits which are encoded by the nuclear MAS1 and MAS2 genes. EMBO Journal, v.7, n.12, p.3857-3862, 1988.

YUAN,J.; HENRY, R.; MCCAFFERY, M.; CLINE, K. SecA-like proteintranslocating machinery in chloroplasts. Trends in Cell Biology, v.5, n.2, p.59, 1995.

ZWIZINSKI, C.; NEUPERT, W. Precursor proteins are transported into mitochondria in the absence of proteolytic cleavage of the additional sequences. The Journal of Biological Chemistry, v.258, n.21, p.1334013346, 1983. 